by Yusuke Suganuma ${ }^{1,2 *}$, Makoto Okada ${ }^{3}$, Martin J. Head ${ }^{4}, K_{\text {Koji Kameo }}^{5}$, Yuki Haneda ${ }^{1,3,6}$, Hiroki Hayashi ${ }^{7}$, Toshiaki Irizuki ${ }^{7}$, Takuya Itaki ${ }^{6}$, Kentaro Izumi ${ }^{8}$, Yoshimi Kubota ${ }^{9}$, Hiroomi Nakazato ${ }^{10}$, Naohisa Nishida ${ }^{11}$, Masaaki Okuda ${ }^{12}$, Yasufumi Satoguchi ${ }^{13}$, Quentin Simon ${ }^{14}$, and Yoshihiro Takeshita ${ }^{15}$

\title{
Formal ratification of the Global Boundary Stratotype Sec- tion and Point (GSSP) for the Chibanian Stage and Middle Pleistocene Subseries of the Quaternary System: the Chiba Section, Japan ${ }^{\dagger}$
}

\footnotetext{
${ }^{\dagger}$ This paper is dedicated to the memory of the late Prof. Hisao Kumai in appreciation of his crucial work in promoting the Chiba section as a candidate for the Middle Pleistocene GSSP

${ }^{1}$ National Institute of Polar Research, 10-3 Midori-cho, Tachikawa, Tokyo 190-8518, Japan; *Corresponding author, E-mail: suganuma.yusuke@niprac.jp

${ }^{2}$ Department of Polar Science, The Graduate University for Advanced Studies (SOKENDAI), Midori-cho 10-3, Tachikawa, Tokyo 190-8518, Japan

${ }^{3}$ Department of Earth Sciences, Ibaraki University, 2-2-1 Bunkyo, Mito, Ibaraki 310-8512, Japan

${ }^{4}$ Department of Earth Sciences, Brock University, 1812 Sir Isaac Brock Way, St. Catharines, Ontario L2S 3A1, Canada

${ }^{5}$ Department of Earth Sciences, Chiba University, 1-33 Yayoi, Inage, Chiba, Chiba 263-8522, Japan

${ }^{6}$ Geological Survey of Japan, AIST, Tsukuba Central 7, 1-1-1 Higashi, Tsukuba, Ibaraki 305-8567, Japan

${ }^{7}$ Interdisciplinary Graduate School of Science and Engineering, Shimane University, Nishikawatsucho 1060, Matsue, Shimane 690-8504, Japan

${ }^{8}$ Faculty and Graduate School of Education, Chiba University, 1-33 Yayoi-cho, Inage, Chiba, Chiba 263-8522, Japan

${ }^{9}$ Department of Geology and Paleontology, National Museum of Nature and Science, 4-1-1 Amakubo, Tsukuba, Ibaraki 305-0005, Japan

${ }^{10}$ Institute for Rural Engineering, NARO, 2-1-6 Kannondai, Tsukuba, Ibaraki 305-8609, Japan

${ }^{11}$ Department of Environmental Sciences, Tokyo Gakugei University, 4-1-1 Nukuikita, Koganei, Tokyo 184-8501, Japan

${ }^{12}$ Natural History Museum and Institute, Chiba, 955-2 Aoba-cho, Chuo, Chiba 260-8682, Japan

${ }^{13}$ Lake Biwa Museum, 1019 Oroshimo-cho, Kusatsu 525-0001, Japan

${ }^{14}$ CEREGE UM34, Aix Marseille Univ, CNRS, IRD, INRAE, Coll France, 13545 Aix en Provence, France

${ }^{15}$ Institute of Education, Shinshu University, 6-ro Nishinagano, Nagano 380-8544, Japan
}

(Received: May 19, 2020; Revised accepted: August 21, 2020)

https://doi.org/10.18814/epiiugs/2020/020080

The Executive Committee of the International Union of Geological Sciences on January 17, 2020 ratified the Global Boundary Stratotype Section and Point (GSSP) defining the base of the Chibanian Stage/Age and Middle Pleistocene Subseries/Subepoch at the Chiba section of the Chiba composite section, Japan. The Chiba composite section is a continuous and expanded marine sedimentary succession in the east-central Japanese archipelago facing the Pacific Ocean. It contains well-preserved pollen, marine micro- and macrofossils, a tightly-defined Matuyama-Brunhes $(M-B)$ paleomagnetic polarity boundary, two geomagnetic field paleointensity proxies, and numerous tephra beds, allowing the establishment of a robust and precise chronostratigraphic framework. Its open-ocean continental slope setting has captured both terrestrial and marine environmental signals from upper Marine Isotope Stage (MIS) 20 to lower MIS 18. The M-B reversal serves as the primary guide for the Lower-Middle Pleistocene boundary, yield- ing an astronomical age of $772.9 \mathrm{ka}$. The GSSP is positioned $1.1 \mathrm{~m}$ below the directional midpoint of the reversal, at the base of a regional lithostratigraphic marker, the OntakeByakubi-E (Byk-E) tephra bed, in the Chiba section. The GSSP has an astronomical age of $774.1 \mathrm{ka}$ and occurs immediately below the top of Marine Isotope Substage $19 \mathrm{c}$.

\section{Introduction}

The Earth experienced a progressive increase in the amplitude of climate oscillations, an evolving waveform, and a shift from $\sim 41 \mathrm{kyr}$ towards a quasi-100 kyr frequency during a $\sim 1.4-0.4$ Ma interval now known as the "Early-Middle Pleistocene transition" (Head and Gibbard, 2015). This transition saw dramatic and progressive changes in oceanic and atmospheric circulation, ice sheet distributions, and biotic evolution (e.g., Head and Gibbard, 2005; Head et al., 2008; Head and Gibbard, 2015).

Deep-ocean records across this climatic transition are plentiful, but 
constructing links between records for atmospheric circulation, terrestrial environmental change, and evolution of the biota is hampered by a scarcity of continuous sedimentary records from continental, coastal and shallow-marine environments. Highly resolved marine records that capture both terrestrial and marine environmental changes with a well-constrained chronology are therefore needed to improve understanding of the Earth's climate system. Especially critical to such reconstructions are well-preserved and diverse microfossils that capture the paleoceanographic changes of a major ocean.

The Matuyama-Brunhes paleomagnetic polarity boundary (M-B boundary), with an age of $\sim 773 \mathrm{ka}$ (e.g., Channell et al., 2010; Channell, 2017; Head and Gibbard, 2015; Valet et al., 2019; Head, 2019; Singer et al., 2019), represents the approximate midpoint of the polarity reversal. At the 32nd International Geological Congress in Florence, 2004, this reversal was chosen by the Early-Middle Pleistocene Boundary Working Group of the Subcommission on Quaternary Stratigraphy (SQS), itself a constituent body of the International Commission on Stratigraphy (ICS), as the primary guide for the boundary (Head et al., 2008). This decision followed an earlier recommendation by Butzer and Isaac (1975) subsequently supported by the INQUA Working Group on Major Subdivision of the Pleistocene at the 12th INQUA Congress in Ottawa in 1987 (Anonymous, 1988; Richmond, 1996). Specifically, the Working Group recommended that the Early-Middle Pleistocene boundary should be defined in a marine section exposed on land, and within plus or minus one marine oxygen isotope stage (MIS) of the M-B boundary (Head et al., 2008). This boundary represents a brief and near-isochronous event and can be observed in marine, glacial and terrestrial records (Richmond, 1996; Pillans, 2003; Head and Gibbard, 2005; Raisbeck et al., 2006; Head et al., 2008).

Three candidates for the Global Boundary Stratotype Section and Point (GSSP) were considered by the Early-Middle Pleistocene Boundary Working Group: the Ideale section of Montalbano Jonico in Basilicata, the Valle di Manche in Calabria, both in southern Italy, and the Chiba section on the Boso Peninsula in Japan. The Chiba section was considered to have the best-defined M-B boundary of the three candidate sections (Head, 2019), and voting within the Working Group concluded on November 10, 2017, with the Chiba proposal gaining 73\% of the total votes cast and hence a supermajority. Voting within the SQS concluded on November 16, 2018, confirming support for the Chiba proposal with a supermajority of $86 \%$. Details of the contending proposals and voting process are given in Head (2019). ICS voting concluded on November 27, 2019 with the following results: 17 in favour, 2 against, no abstentions, with 19 ballots received, giving a supemajority of $89.5 \%$. ICS therefore approved the GSSP defining the coterminous base of the Chibanian Stage and Middle Pleistocene Subseries at the Chiba section of the Chiba composite section, Japan. On January 17, 2020, the Executive Commitee of the International Union of Geological Sciences (IUGS EC) ratified this decision. The Chibanian is now the third formally defined stage of the Pleistocene Series and Quaternary System. The present publication is based on the proposal approved by the ICS and ratified by the IUGS EC, which itself draws heavily on Suganuma et al. (2018). A complementary proposal formalizing the Lower and Upper Pleistocene subseries (the latter in name only) was ratified on January 30, 2020 (Head et al., this issue).

The Chiba composite section belongs to the Kokumoto Formation of the Kazusa Group. It is located near the Pacific coast of the central part of the Japanese archipelago (Fig. 1), and is a continuous marine silty sedimentary record representing one of the most expanded and chronostratigraphically constrained sections yet documented across the Lower-Middle Pleistocene (e.g., Kazaoka et al., 2015; Suganuma et al., 2018). This composite section consists (west to east) of the Urajiro, Yanagawa, Yoro River, Yoro-Tabuchi, and Kokusabata sections, covering a total distance of $7.4 \mathrm{~km}$ along strike (Figs. 2, 3, and Supplementary Fig. 1). The GSSP is located in the Chiba section, a segment of the Yoro River section (Suganuma et al., 2018) and a direct continuation of the Yoro-Tabuchi section. The Chiba composite section contains well-preserved pollen, various marine micro- and macrofossil groups, a paleomagnetic reversal event, and a large number of tephra beds, facilitating a robust chronostratigraphic framework. Because the section is located at the easternmost margin of the Eurasian continent open to the Pacific Ocean, the marine sedimentary record preserves the interplay between terrestrial and marine paleoclimatic and paleoenvironmental changes influenced by the mid-latitude westerly jet stream, East Asian monsoon, and North Pacific Gyre, ranging from subtropical to subpolar settings. The $\mathrm{M}-\mathrm{B}$ boundary occurs immediately above a widespread tephra bed, the Ontake-Byakubi-E (Byk-E), found throughout the Chiba composite section (Suganuma et al., 2015; Hyodo et al., 2016; Okada et al., 2017; Haneda et al., 2020a) (Fig. 4). The Byk-E tephra has a zircon U-Pb age of $772.7 \pm 7.2 \mathrm{ka}$ (Suganuma et al., 2015) and represents an excellent local and regional stratigraphic marker for the Lower-Middle Pleistocene boundary. The GSSP itself is located at $35^{\circ} 17^{\prime} 39.6^{\prime \prime} \mathrm{N}, 140^{\circ} 08^{\prime} 47.6^{\prime \prime} \mathrm{E}$ in the Chiba section at the lower boundary of the Byk-E tephra bed. The Chiba and nearby Yoro-Tabuchi sections have yielded an ultra-high-resolution oxygen isotope $\left(\delta^{18} \mathrm{O}\right)$ stratigraphic record, and records based on pollen, marine microfossils, and macrofossils, as well as other geochemical and sedimentological proxies (Fig. 3), that provide additional stratigraphic markers to recognize the boundary interval on a regional and global scale. The GSSP has an astronomical age of $774.1 \mathrm{ka}$ and occurs just below the top of Marine Isotope Substage 19c. MIS 19c corresponds to the best orbital analogue for the current interglacial (e.g., Tzedakis et al., 2012).

\section{Geological setting}

The Kazusa Group is one of the thickest $(\sim 3,000 \mathrm{~m})$ and best exposed Lower and Middle Pleistocene marine sedimentary successions in the Japanese archipelago (e.g., Ito, 1998; Kazaoka et al., 2015; Ito et al., 2016). It represents the infill of the Kazusa fore-arc basin, developed in response to the west-north-westward subduction of the Pacific plate beneath the Philippine Sea plate along the Japan and Izu-Bonin trenches (e.g., Seno and Takano, 1989). The Kazusa Group in the Boso Peninsula (part of the Chiba Prefecture) is especially well exposed and contains a remarkably continuous stratigraphic record (Figs. 2 and 5). The Kazusa Group strikes NE-SW and dips gently to the northwest in this region. This structure originated from uplift along the axial part of the Peninsula in the late Middle Pleistocene (e.g., Mitsunashi et al., 1979).

The thickest succession crops out along the Yoro River (Fig. 2) where many studies including those dealing with lithostratigraphy, biostratigraphy, magnetostratigraphy, and $\delta^{18} \mathrm{O}$ stratigraphy give an estimated age of $\sim 2.4-0.45 \mathrm{Ma}$ (Fig. 5) (Ito et al., 2016), indicating that the Chiba composite section is located in and around MIS 19. Numerous key 


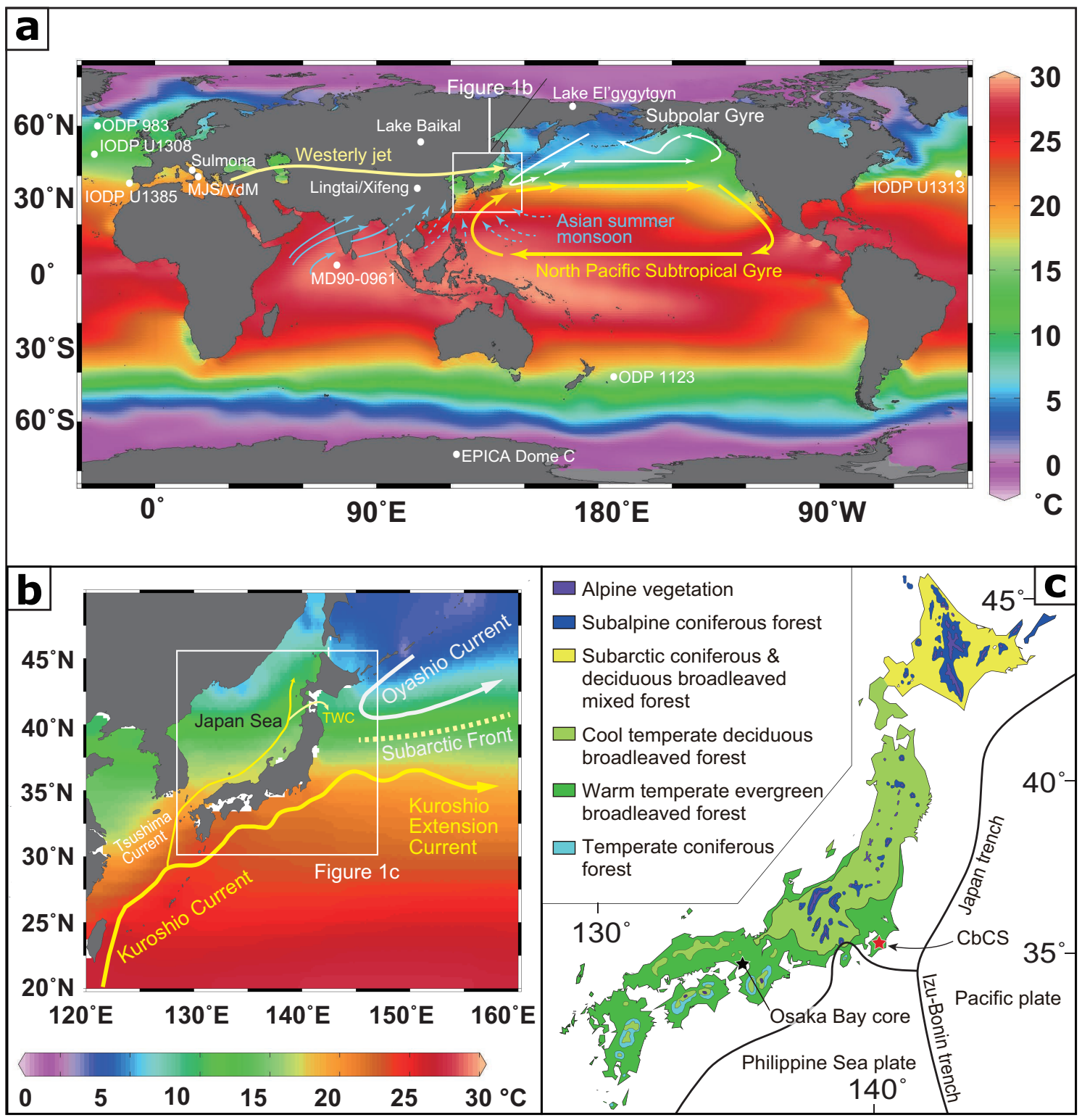

Figure 1. Location and setting of the Chiba composite section, Kokumoto Formation, in the Kazusa Group, east-central part of the Japanese archipelago. (a) and (b) Oceanographic and atmospheric setting of the Japanese archipelago in summer. Location of the westerly jet during summer is based on Zhang et al. (2011). Positions of the major ocean currents in the North Pacific are based on Brown et al. (2001). The ocean temperature gradients in these figures are based on the World Ocean Atlas 2013 (Locarnini et al., 2013) drawn using Ocean Data View software (Schlitzer, 2015). An arrow in (b) indicates the Tsugaru Warm Current (TWC) which flows from the Sea of Japan to the Pacific Ocean. The boxes mark the location of Fig. $1 \mathrm{~b}$ and 1c, respectively. (c) Potential vegetation map of the Japanese archipelago simplified from Yoshioka (1973). The locations of a corehole from Osaka Bay, other ocean drilling sites, onshore sections, and an Antarctic ice core referred to in discussions are shown. Abbreviations: MJS, Montalbano Jonico section; VdM, Valle di Manche section; CbCS, Chiba composite section.

tephra beds have facilitated detailed stratigraphic correlation and integration of age data using various dating methods (e.g., Satoguchi and Nagahashi, 2012).

\section{Present Oceanic and Terrestrial Environments}

The Boso Peninsula currently faces the northwestern Pacific Ocean, where the subtropical Kuroshio and subarctic Oyashio currents form the Subarctic Front, with the Oyashio Current descending beneath the Kuroshio Current (Figs. 1a and 1b). The mixing of these currents cre- ates a pronounced latitudinal sea-surface temperature (SST) gradient which is greatest off the Boso Peninsula. The interaction of these two currents has been in operation since at least the Pleistocene (Okazaki et al., 2010; Gallagher et al., 2015).

High mountain ranges up to $\sim 3000 \mathrm{~m}$ above sea level presently occur in the central part of the Japanese archipelago to the west of the Boso Peninsula (Fig. 1c). The present-day vegetation of the Kanto flatland, northwest of the Boso Peninsula, is mainly warm-temperate broadleaved evergreen forest, whereas cool-temperate deciduous broadleaved and coniferous forests characterize the surrounding higherrelief ranges of the Kanto Basin as well as the northern part of the main 


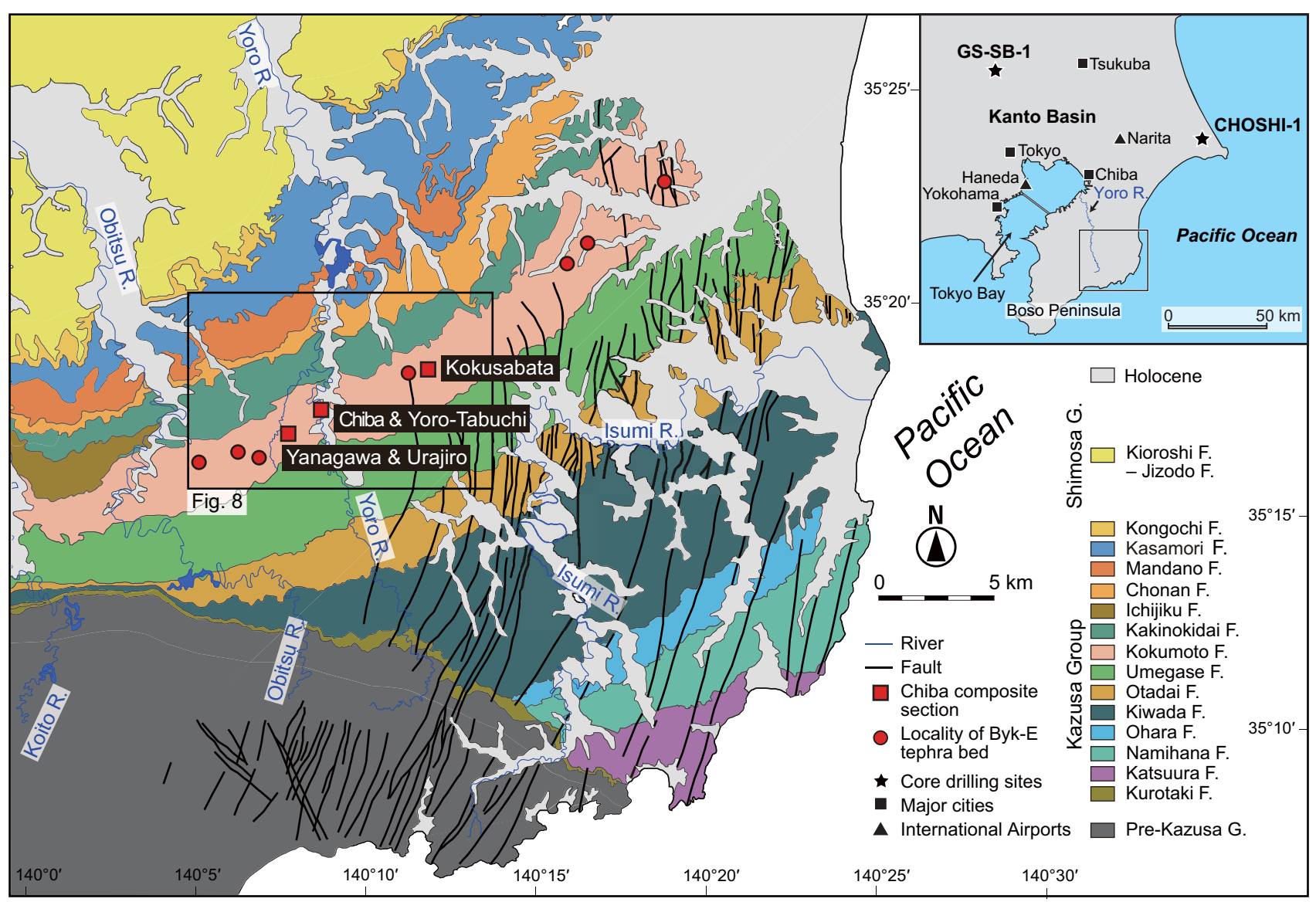

Figure 2. Simplified geological map of the Boso Peninsula based on Mitsunashi et al. (1961) and Ishiwada et al. (1971). The box corresponds to the geological map in Fig. 8. Red boxes and circles are locations of the Chiba composite section and Byk-E tephra bed.

island of Japan (Fig. 1c; Yoshioka, 1973). All paleoclimatic, paleoceanographic, and terrestrial environmental records are integrated in the Kazusa Group and adjacent sedimentary successions.

\section{Age Model and Chronological Framework}

In order to develop a detailed age model for the Chiba composite section including the M-B boundary, an ultra-high-resolution $\delta^{18} \mathrm{O}$ stratigraphy was established using the benthic foraminiferal species Bolivinita quadrilatera and Cibicides aknerianus taken from $\sim 10-50$ $\mathrm{cm}$ intervals (Haneda et al., 2020b), combined with lower resolution data from Suganuma et al. (2015) and incorporating data from Okada et al. (2017) and Suganuma et al. (2018) (Fig. 6). The present paper uses the age model of Suganuma et al. (2018) which was then established through correlation of the $\delta^{18} \mathrm{O}$ benthic record with the sea level curve of Elderfield et al. (2012) constructed by subtracting the effects of deep-water temperature (using benthic foraminiferal $\mathrm{Mg} / \mathrm{Ca}$ ratios) on the $\delta^{18} \mathrm{O}$ signal of benthic foraminifera from ODP Site 1123 located in the Southwestern Pacific (Fig. 7) (see details in Suganuma et al., 2018; Haneda et al., 2020b). Age model uncertainty is thought to be ca. $5 \mathrm{kyr}$ inferred from the chronologic uncertainty of $4 \mathrm{kyr}$ in the LR04 stack (Lisiecki and Raymo, 2005) used as a target curve by Elderfield et al. (2012) plus another ca. $1 \mathrm{kyr}$ of uncertainty in our tuning to the Elderfield et al. (2012) record.
The resulting age model yields a depositional age spanning the upper half of MIS 20 through lower half of MIS 18, with astronomically tuned ages from 801.1 ka to $747.6 \mathrm{ka}$ (Figs. 6 and 7). This model gives $44 \mathrm{~cm} / \mathrm{kyr}$ as a minimum sedimentation rate during the interval of highest global sea level (Elderfield et al., 2012). MIS 19 substages (MIS 19c, 19b, and 19a) are assigned using the climatic variables proposed by Nomade et al. (2019): MIS 19c corresponds to the onset and climatically stable part (main part) of Stage 19, MIS 19b to the first climatic cooling, and MIS 19a to the most unstable part of Stage 19. Astronomical ages for each of the MIS and substage boundaries are estimated to be $787.5 \mathrm{ka}$ (MIS 20-19c), $773.9 \mathrm{ka}$ (MIS 19c-19b), $770.1 \mathrm{ka}$ (MIS 19b-19a), and $756.9 \mathrm{ka}$ (MIS 19a-18) based on the full $\delta^{18} \mathrm{O}$ benthic dataset of the Chiba composite section (Haneda et al., 2020b).

The $\delta^{18} \mathrm{O}$ stratigraphy for the nearby CHOSHI-1 core, located in the easternmost part of the Boso Peninsula (Fig. 2), covers MIS 24 to MIS 11 (Kameo et al., 2006) and supplements the age model for the Chiba composite section (Fig. 6). Three tephra beds, Ku1, Ku2B, and Ku3 (Yk9, Yk8.5, and Yk7.5 in the CHOSHI-1 core, respectively), are common to both sections, and facilitate comparison. The Globorotalia inflata $\delta^{18} \mathrm{O}$ record of the CHOSHI-1 core closely matches that of the Chiba composite section even at the scale of minor fluctuations (Fig. 6). The Kul tephra is located above the MIS 19-18 boundary in the CHOSHI- 1 core, so that the upper limit of the Chiba composite section appears to be above the MIS 19-18 boundary. 


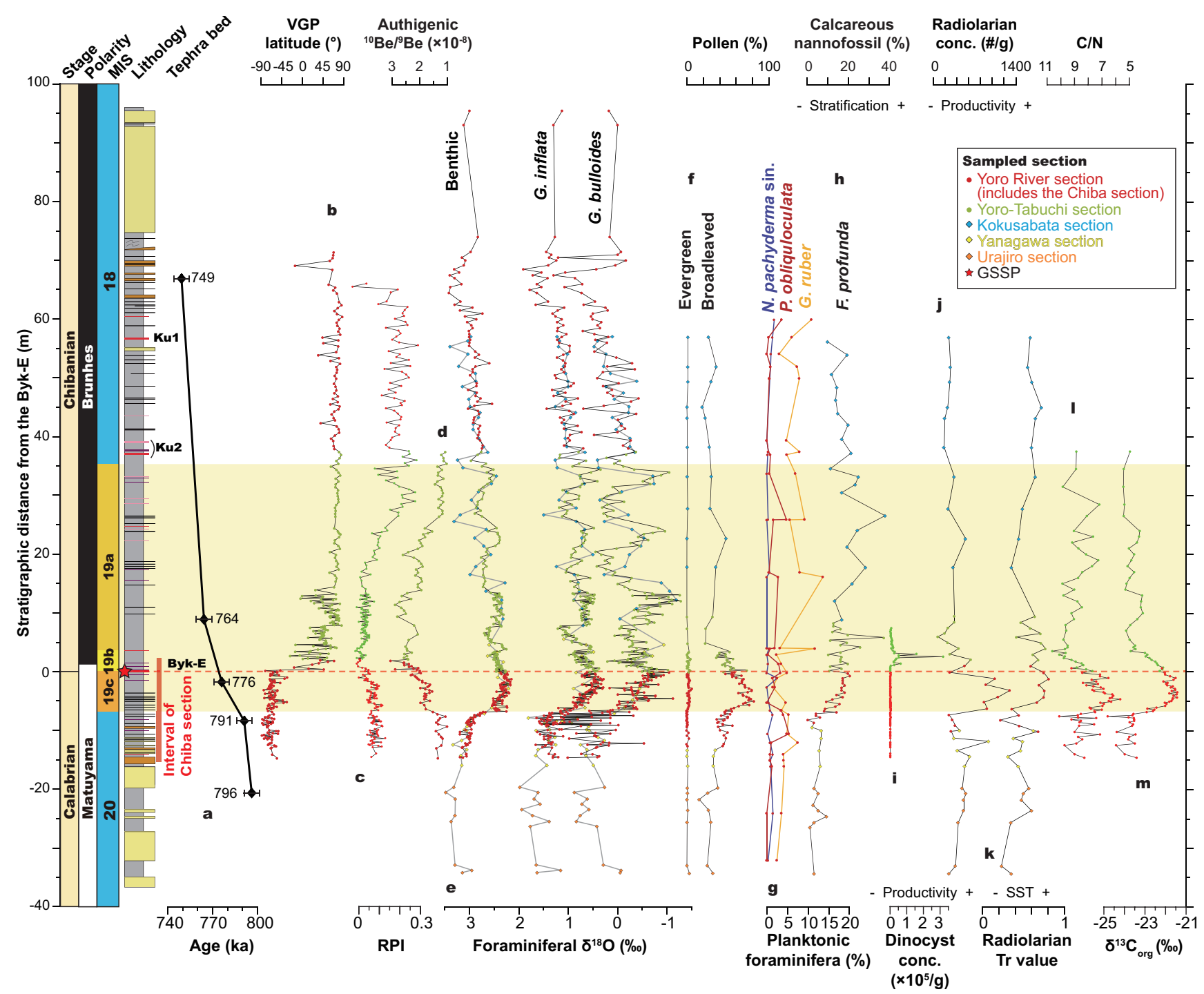

Figure 3. Litho-, magneto, stable isotope stratigraphy of the Chiba composite section with paleoceanographic and paleoclimatic proxy records. (a): Age-depth profile of the Chiba composite section. (b)-(d): Matuyama-Brunhes boundary is clearly recognized (Okada et al., 2017), supported by a significant geomagnetic field intensity drop across the boundary indicated by paleomagnetic and cosmogenic ${ }^{10}$ Be records $($ Simon et al., 2019; Haneda et al., 2020a). (e): Ultra-high-resolution oxygen isotope $\left(\delta^{18}\right.$ ) stratigraphy from benthic and planktonic foraminifera (Suganuma et al., 2015; Okada et al., 2017; Suganuma et al., 2018; Haneda et al., 2020b). (f): Relative abundance of evergreen and broadleaved pollen (Suganuma et al., 2018). (g): Relative abundance of planktonic foraminifera G. ruber, P. obliquloculata, and N. pachyderma sin. (Suganuma et al., 2018; Shikoku et al., in review). (h): Relative abundance of calcareous nannofossil F. profunda (Kameo et al., 2020). (i): Dinoflagellate cyst (dinocyst) concentation (Balota et al., in press). (j): Concentration of radiolarians (Suganuma et al., 2018). (k) Seasurface temperature (SST) index based on warm- and cold-water radiolarian species (Tr values) (Suganuma et al., 2018). (l) C/N ratio (=total organic carbon: TOC/total nitrogen) (Izumi et al., 2020). (m) Stable organic carbon isotope $\left(\delta^{13} C_{o r g}\right)$ (Izumi et al., 2020). Section from which each sample was collected is indicated by the color: red, Yoro River (including the Chiba section); light green, Yoro-Tabuchi; light blue, Kokusabata; yellow, Yanagawa; and orange, Urajiro. Abbreviations: VGP, virtual geomagnetic pole; RPI, relative paleointensity.

\section{Lithostratigraphy of the Chiba Composite Section}

\section{Exposure and component sections}

The Kokumoto Formation occurs in the upper part of the Kazusa Group, and represents an expanded and well-exposed sedimentary succession across the Lower-Middle Pleistocene boundary, especially at the Chiba composite section. The Chiba composite section comprises (west to east) the Urajiro $\left(35^{\circ} 16^{\prime} 52.4^{\prime \prime} \mathrm{N}, 140^{\circ} 07^{\prime} 28.2^{\prime \prime} \mathrm{E}\right.$ to $35^{\circ} 16^{\prime} 49.4^{\prime \prime} \mathrm{N}$, $\left.140^{\circ} 07^{\prime} 28.3^{\prime \prime} \mathrm{E}\right)$, Yanagawa $\left(35^{\circ} 17^{\prime} 08.9^{\prime \prime} \mathrm{N}, 140^{\circ} 07^{\prime} 52.9^{\prime \prime} \mathrm{E}\right.$ to $35^{\circ} 17^{\prime} 05.8^{\prime \prime} \mathrm{N}$, $\left.140^{\circ} 07^{\prime} 51.0^{\prime \prime} \mathrm{E}\right)$, Yoro River ( $35^{\circ} 17^{\prime} 59.6^{\prime \prime} \mathrm{N}, 140^{\circ} 08^{\prime} 34.8^{\prime \prime} \mathrm{E}$ to $35^{\circ} 17^{\prime} 36.9^{\prime \prime}$ $\left.\mathrm{N}, 140^{\circ} 08^{\prime} 47.2^{\prime \prime} \mathrm{E}\right)$, Yoro-Tabuchi ( $35^{\circ} 17^{\prime} 48.1^{\prime \prime} \mathrm{N}, 140^{\circ} 09^{\prime} 02.1^{\prime \prime} \mathrm{E}$ to $\left.35^{\circ} 17^{\prime} 41.1^{\prime \prime} \mathrm{N}, 140^{\circ} 08^{\prime} 49.7^{\prime \prime} \mathrm{E}\right)$, and Kokusabata $\left(35^{\circ} 18^{\prime} 43.2^{\prime \prime} \mathrm{N}\right.$, $140^{\circ} 11^{\prime} 45.7^{\prime \prime} \mathrm{E}$ to $35^{\circ} 18^{\prime} 32.7^{\prime \prime} \mathrm{N}, 140^{\circ} 11^{\prime} 53.6^{\prime \prime} \mathrm{E}$ ) sections (Figs. 8, 9, and Supplementary Fig. 1). The Chiba section ( $35^{\circ} 17^{\prime} 39.6^{\prime \prime} \mathrm{N}, 140^{\circ} 08^{\prime} 47.6^{\prime \prime} \mathrm{E}$ to $35^{\circ} 17^{\prime} 36.9^{\prime \prime} \mathrm{N}, 140^{\circ} 08^{\prime} 47.2^{\prime \prime} \mathrm{E}$ ), exposed along the gorge wall of the Yoro River, is a segment of the Yoro River section (Figs. 10 and 11) and contains the GSSP. These component sections, spanning $7.4 \mathrm{~km}$ along strike, reveal a laterally and vertically continuous succession through- 


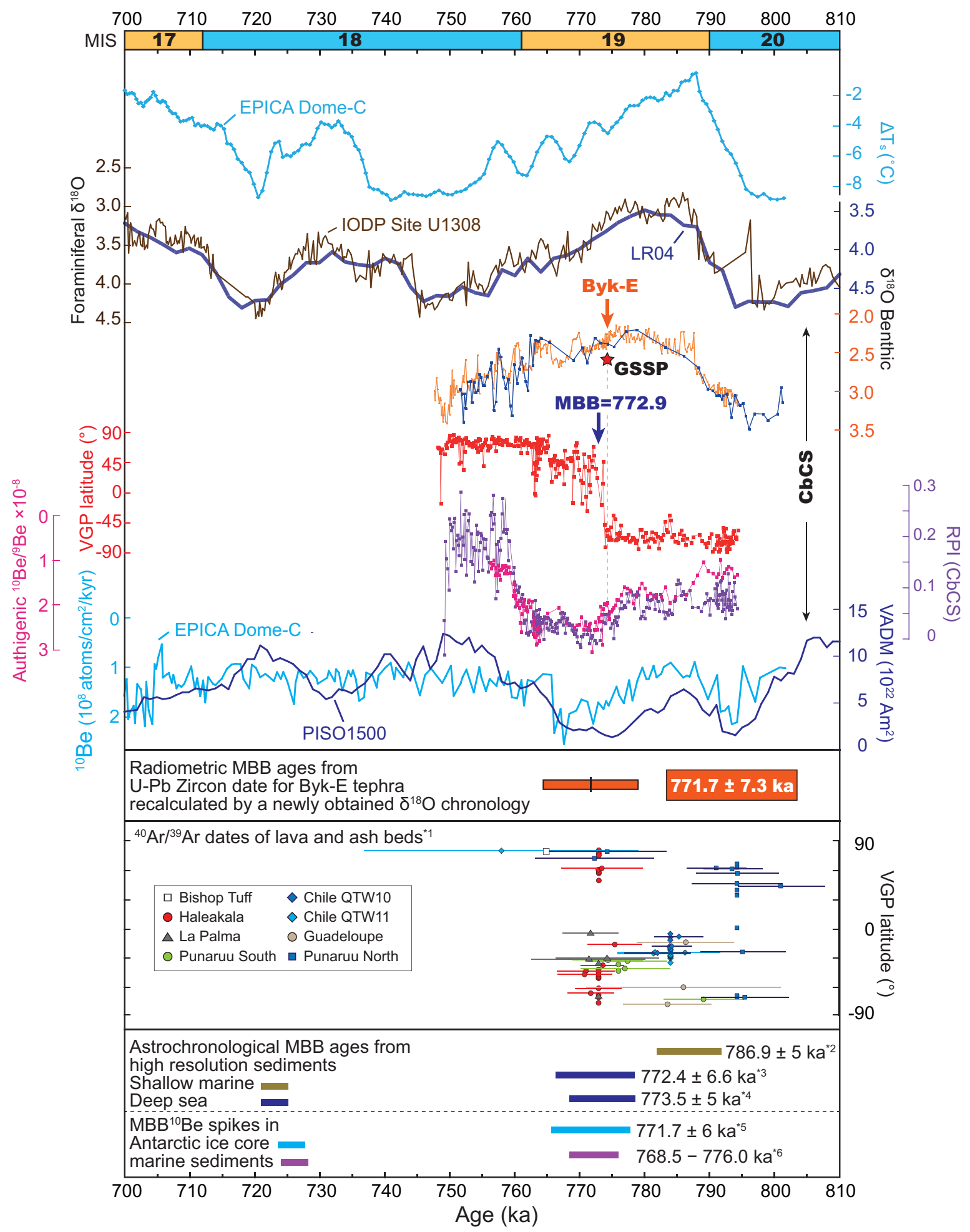

Figure 4. The astronomical and radiometric (U-Pb zircon dating) $M-B$ boundary ages from the Chiba composite section (CbCS) in comparison with other ages for the boundary based on astronomical tuning of marine sediments and an Antarctic ice core, and ${ }^{40}$ Ar ${ }^{\beta^{9}}$ Ar ages for lava flow sequences. Paleoclimatic proxies are also shown for comparison. The oxygen isotope $\left(\delta^{18} \mathrm{O}\right)$ stratigraphy is from IODP U1308 $($ Channell et al., 2010), LR04 (Lisiecki and Raymo 2005), and the CbCS (Suganuma et al., 2015; Okada et al., 2017; Suganuma et al., 2018; Haneda et al., 2020b), and the temperature change is inferred from the deuterium content of the EPICA Dome C ice core (Jouzel et al., 2007). ${ }^{10}$ Be flux data are from the EPICA Dome C ice core (Raisbeck et al., 2006; Dreyfus et al., 2008), and authigenic ${ }^{10}$ Bef Be ratio (inverted) from the CbCS (Simon et al., 2019). Paleointensity data are from the global stack (PISO1500; Channell et al., 2009) and the CbCS (Haneda et al., 2020a). The EPICA Dome C data are corrected to the AICC2012 ice-core chronology (Bazin et al., 2013). Asterisk numbers, *1: Singer et al. (2019), *2: Capraro et al. (2017), *3: Valet et al. (2019), *4: Channell et al. (2010), *5: Raisbeck et al. (2006), Dreyfus et al. (2008), *6: Simon et al. (2018b). Abbreviations: MBB, Matuyama-Brunhes boundary; VGP, virtual geomagnetic pole; RPI, relative paleointensity; VADM, Virtual axial dipole moment. The orange arrow indicates the stratigraphic location of the Byk-E tephra bed. 

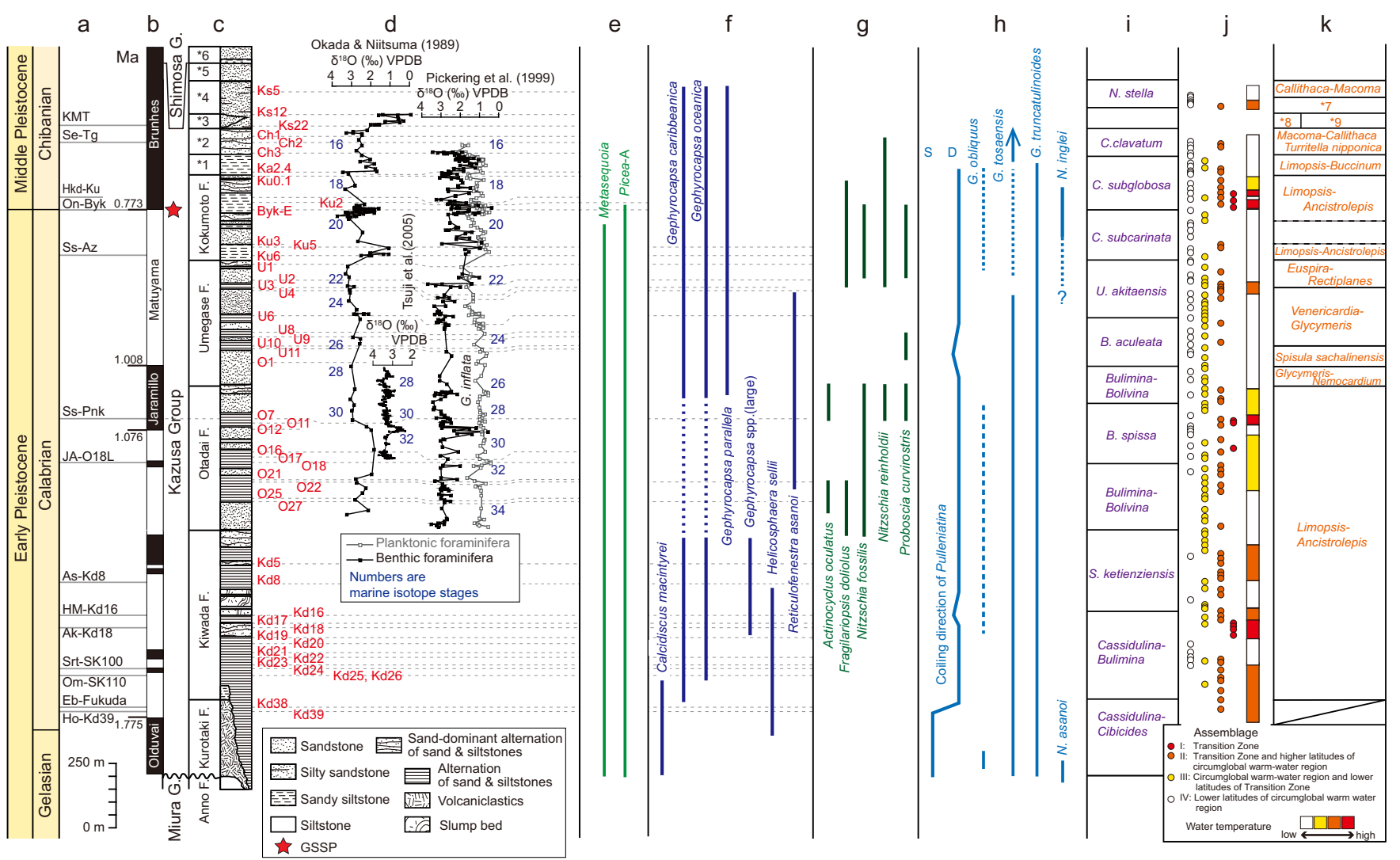

Figure 5. Chronostratigraphic and chronologic summary of the Kazusa Group modified from Kazaoka et al. (2015). (a) Tephrochronology of the widespread tephra beds in the Kazusa Group (Satoguchi and Nagahashi, 2012). (b) Magnetostratigraphy (Niitsuma, 1976), with ages based on Singer et al. (2019). (c) Lithostratigraphy based on Mitsunashi et al. (1961) with traceable tephra beds. *1: Kakinokidai Formation, *2: Chonan Formation, *3: Mandano Formation, *4: Kasamori Formation, *5: Kongochi Formation, *6: Jizodo Formation. For detailed lithology of the Kazusa Group and descriptions of the tephra beds, see Kazaoka et al. (2015). (d) Oxygen isotopes of planktonic and benthic foraminifera. Planktonic data are from $\mathrm{G}$. inflata (Pickering et al., 1999), and benthic data represent several species calibrated to Uvigerina spp. (Okada and Niitsuma, 1989; Pickering et al., 1999; Tsuji et al., 2005). (e) Stratigraphic distribution of main pollen taxa (Onishi, 1969). (f-h) Stratigraphic distributions of index species for (f) calcareous nannofossils (Sato et al., 1988, 1999), (g) diatoms (Cherepanova et al., 2002), and (h) planktonic foraminifera (Oda, 1977, 1979; Igarashi, 1994; Shikoku et al., in revision). (i) Benthic foraminiferal assemblages (Aoki, 1968). (j) Planktonic gastropods and estimated paleotemperatures (Ujihara, 1986). (k) Molluscan assemblages (Baba, 1990). *7: Portlandia-Striodentalium, Nemocardium samarangae, Macoma calcarea, *8: Nemocardium-Limopsis, Spisula-Glycymeris, *9: PortlandiaStriodentalium, Limopsis tokaiensis tajimae.

out the Lower-Middle Pleistocene boundary interval. The Chiba section itself is more than $17.7 \mathrm{~m}$ thick (Figs. 12 and 13) (Fig. 12 is from Nishida et al., 2016, as the Tabuchi section), extending from upper MIS 20 to MIS $19 \mathrm{~b}$ and occurring within the middle part of the Kokomoto Formation. It is ca. $70 \mathrm{~m}$ from the Yoro-Tabuchi section - they represent lateral and vertical extensions of the same outcrop interrupted by vegetation but linked tightly by four tephra beds (Byk-E-B) in the interval of the M-B boundary (Figs. 8 and 12). The continuity of the succession throughout the Lower-Middle Pleistocene boundary interval and the stratigraphic horizon of the M-B boundary is also confirmed by a drilled sediment core (TB-2) located 190 m northeast of the Chiba section (Figs. 11, 13, Supplementary Fig. 1) (Hyodo et al., 2016). Very detailed tephrostratigraphic and stratigraphic investigations complement the high-resolution stratigraphic correlation within the Chiba composite section, and enable an integrated stratigraphy to be developed for this composite section (Fig. 9). Detailed sampling locations and horizons are summarized in Haneda et al. (2020a), Table 1, and Supplementary Fig. 1.

\section{Sedimentary Facies and Sequence Stratigraphic Framework}

Exposures of the Chiba composite section, including the Chiba section itself, are dominated by bioturbated, hemipelagic, silty beds, reflecting deposition of fine-grained suspended material under quiescent bottom-water conditions. Detailed field observations and laboratory experiments using soft-X radiographs, grain-size analyses, thin sections, and ichnofossils show no evidence of unconformities, slump scars or other remarkable erosional structures that could indicate the presence of distinctive episodic events, stratigraphic gaps, or hiatuses (Nishida et al., 2016). Photographs from the Chiba section indicate that the bedding planes are parallel and that no erosional structures are present (Fig. 10). The median grain size of the silty beds ranges from 6.8 to $28.7 \mu \mathrm{m}$. No obvious vertical variation in grain size is recognised throughout the section particularly across the Lower-Middle Pleistocene boundary. The grain size of the section below the boundary, associated with minor sandy beds, tends to be more variable, and is attributed to the influence of bioturbation. Although minor sandy 


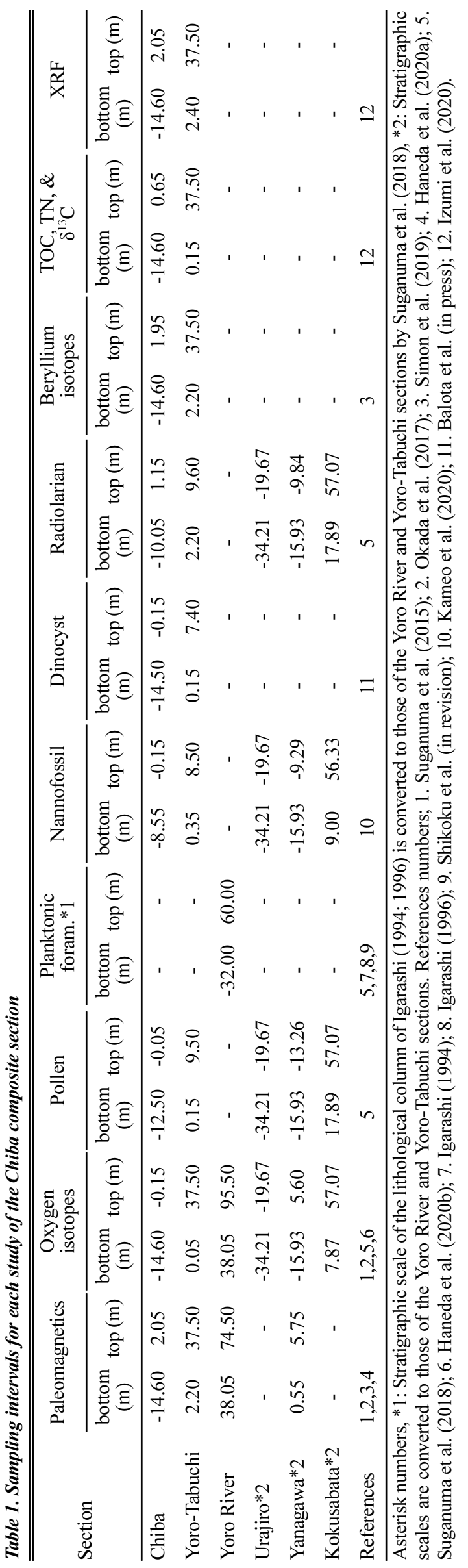




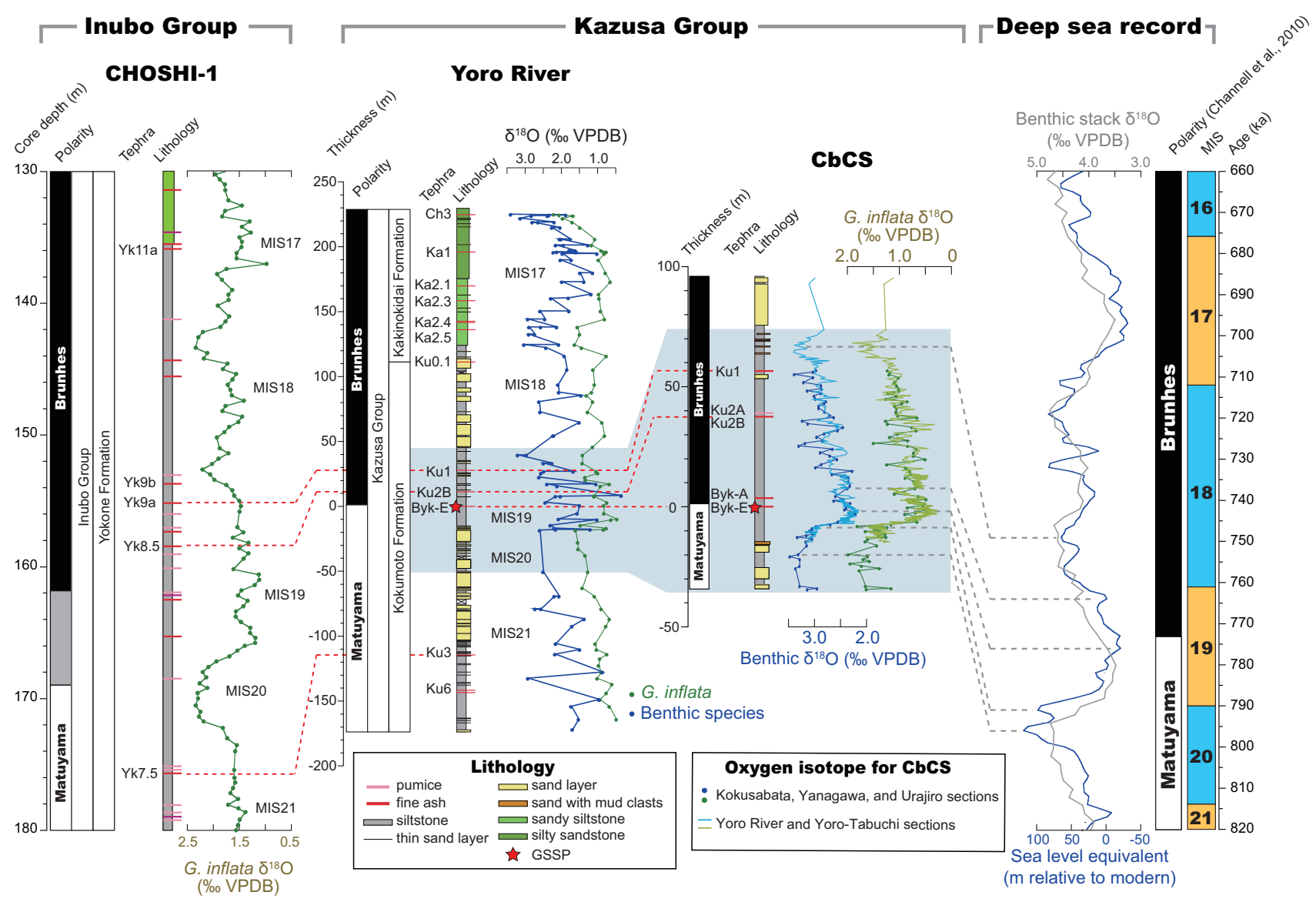

Figure 6. Chronostratigraphic correlations between the Kazusa Group, including the Chiba composite section (CbCS), and deep-sea records modified and corrected from Suganuma et al. (2018). The age model is based on visual matching with the sea level proxy of Elderfield et al. (2012). The LR04 benthic stack (Lisiecki and Raymo, 2005) is also shown for comparison. A high-resolution oxygen isotope ( ${ }^{18} O$ ) stratigraphy from the CbCS (Suganuma et al., 2015; Okada et al., 2017; Suganuma et al., 2018; Haneda et al., 2020b), in addition to the low resolution record of the Yoro River (Pickering et al., 1999), is also correlated to the $\delta^{18}$ O stratigraphy from the CHOSHI-1 core (Kameo et al., 2006), based on marker tephra bed correlations and major features of the $\delta^{18} O$ record. Abbreviation: VPDB, Vienna Pee Dee Belemnite; MIS, Marine Isotope Stage. The ages of the MIS boundaries follow Lisiecki and Raymo (2005) and are taken from http://www.lorraine-lisiecki.com/LR04_MISboundaries.txt.

beds of sediment gravity-flow origin are intercalated within the silty section, particularly in its lower part, the section is generally thought to represent a stable depositional unit (Nishida et al., 2016). The main part of the Chiba composite section, dominated by silty beds, is assigned to transgressive and highstand systems tracts of a fifth order depositional sequence as defined by Mitchum and VanWagoner (1991) during MIS 19 (Ito et al., 2016; Takao et al., 2020). The Byk-E tephra bed is correlated to the uppermost transgressive systems tract, almost a downlap surface (Takao et al., 2020). A detailed stratigraphic log and grain-size analysis of the Chiba section is shown in Fig. 12.

\section{Depositional Environment}

Overall the Kokumoto Formation including the interval of the Chiba composite section has been interpreted to represent deposition on a shelf edge to continental slope environment (Ito, 1992; Ito and Katsura, 1992; Ito et al., 2006a and b; Nakamura et al., 2007).

Ichnogenera, mainly from the Chiba section (Nishida et al., 2016), are typical of deep-sea siliciclastic systems (Hubbard et al., 2012; Uchman and Wetzel, 2012; Wetzel and Uchman, 2012). However, the absence of graphoglyptid trace fossils, which are typical of basin plain deposits and not generally associated with continental slope deposits, imply a slope setting. The trace fossil association of the Chiba composite section is typical of the Zoophycos ichnofacies (Nishida et al., 2016), and suggests water depths exceeding 800 to $1000 \mathrm{~m}$ based on the modern distribution of Zoophycos (Löwemark and Werner, 2001). The Chiba composite section, including the Chiba section itself, is thus interpreted as having been deposited on the continental slope under generally stable conditions and devoid of the wave/current influences that are common in shelf environments (Nishida et al., 2016).

\section{Biostratigraphy}

The Kazusa Group includes abundant marine and terrestrial remains as both micro- and macrofossils, as summarized by Kazaoka et al. (2015), that have allowed the Brunhes Chronozone to be identified (e.g., Niitsuma et al., 1976; Okada and Niitsuma, 1989; see Magnetostratigraphy section). Within the M-B boundary interval, there are few useful biostratigraphic datums of global significance. Planktonic fora- 


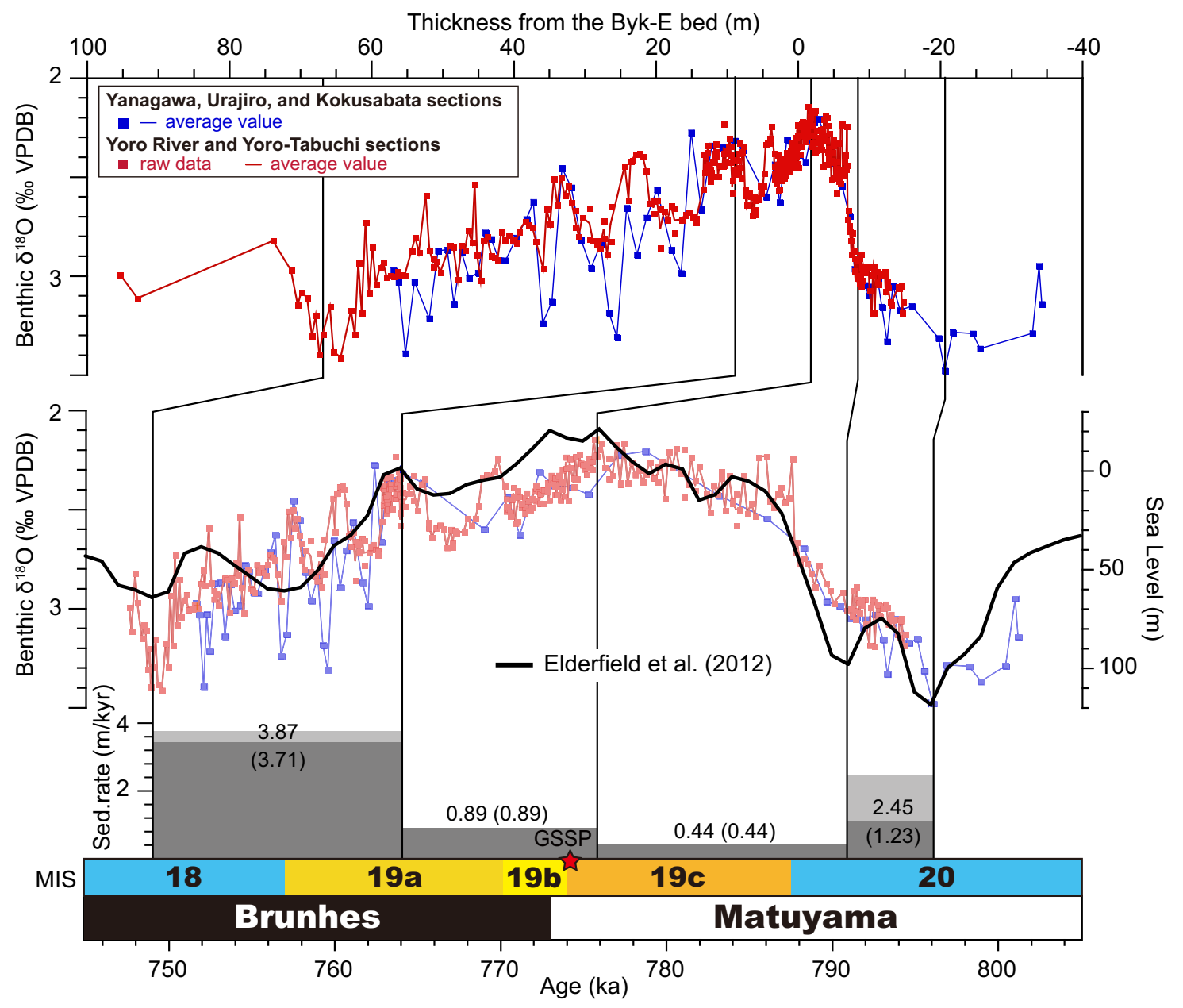

Figure 7. Age-depth model based on the high-resolution oxygen isotope $\left(\delta^{18} \mathrm{O}\right)$ stratigraphy from the Chiba composite section (CbCS) modified from Haneda et al. (2020b). Sedimentation rates for the CbCS are calculated using the age model and thickness of the section with (grey bars) and without (black bars) the sandstone (no sandstones during MIS 19) where the sandstone is considered to be turbiditic (instantaneous) deposition. Abbreviations: VPDB: Vienna Pee Dee Belemnite, MIS: marine isotope stage.

miniferal (sub-)zones N22 and Ptla broadly span the boundary (Wade et al., 2011; Hilgen et al., 2012), as do calcareous nannofossil zones CN14 and NN19 (Anthonissen and Ogg, 2012). The Chiba composite section falls well within the limits of these biozones.

\section{Pollen Assemblages}

A detailed pollen record of the Chiba composite section constructed at high temporal resolution ( $\sim 110$ year sample spacing for the highest resolution intervals) from 801.1 to $751.6 \mathrm{ka}$ (late MIS 20 to early MIS 18) has allowed subdivision into seven (sub-)zones, CbCS-1a through CbCS-3c (Figs. 14-16; Suganuma et al., 2018). This record utilizes all components of the composite section, although the critical interval from the base of Subzone CbCS- $1 b$ to the base of CbCS-3b are from the Chiba section and immediately superjacent Yoro-Tabuchi section. The palynoflora consists of tree pollen (80-90\%) dominated by Pinus. Among other members of the family Pinaceae, the genera Picea, Abies, and Tsuga are important elements as boreal conifers, with deciduous broadleaved trees dominated by Quercus (subgenus Lepidobalanus, hereafter referred to Quercus) and Fagus. Based on the present-day vege- tational distribution of natural forest communities across the Japanese archipelago (Fig. 1c), the Chiba pollen record reflects regional vegetational changes in the eastern to northern parts of the Japanese archipelago. The ratio of broadleaved tree pollen to the total arboreal pollen (broadleaved/AP) and mean annual temperature $\left(\mathrm{T}_{\text {ann }}\right)$, as obtained by the modern analogue technique (MAT) (Nakagawa et al., 2002), both significantly increase during MIS 19c, supporting the age model based on foraminiferal isotopes. The dominant Pinus is excluded from the both broadleaved/AP and the MAT calculation as Pinus pollen tends to be overrepresented in deep-sea sediments because of its buoyant character (Heusser, 1990; Okuda et al., 2006). Boreal coniferous trees decrease during MIS 19c and then increase towards MIS 18 (Fig. 15). The duration of full interglacial conditions within MIS 19 is estimated to be ca. $10 \mathrm{ka}$ (785.0 to $775.1 \pm 5 \mathrm{ka})$ (Suganuma et al., 2018), which is statistically indistinguishable with the MIS 19c duration recorded in the lacustrine Sulmona section (10.8 ka; Giaccio et al., 2015) and Montalbano Jonico section (MJS) (11.5 \pm 3.4 ka; Nomade et al., 2019) from Italy, and from North Atlantic records (e.g., 10.5-12.5 ka; Tzedakis et al., 2012). Significantly, full interglacial conditions are followed by a brief cooling event at $774 \mathrm{ka}$ 

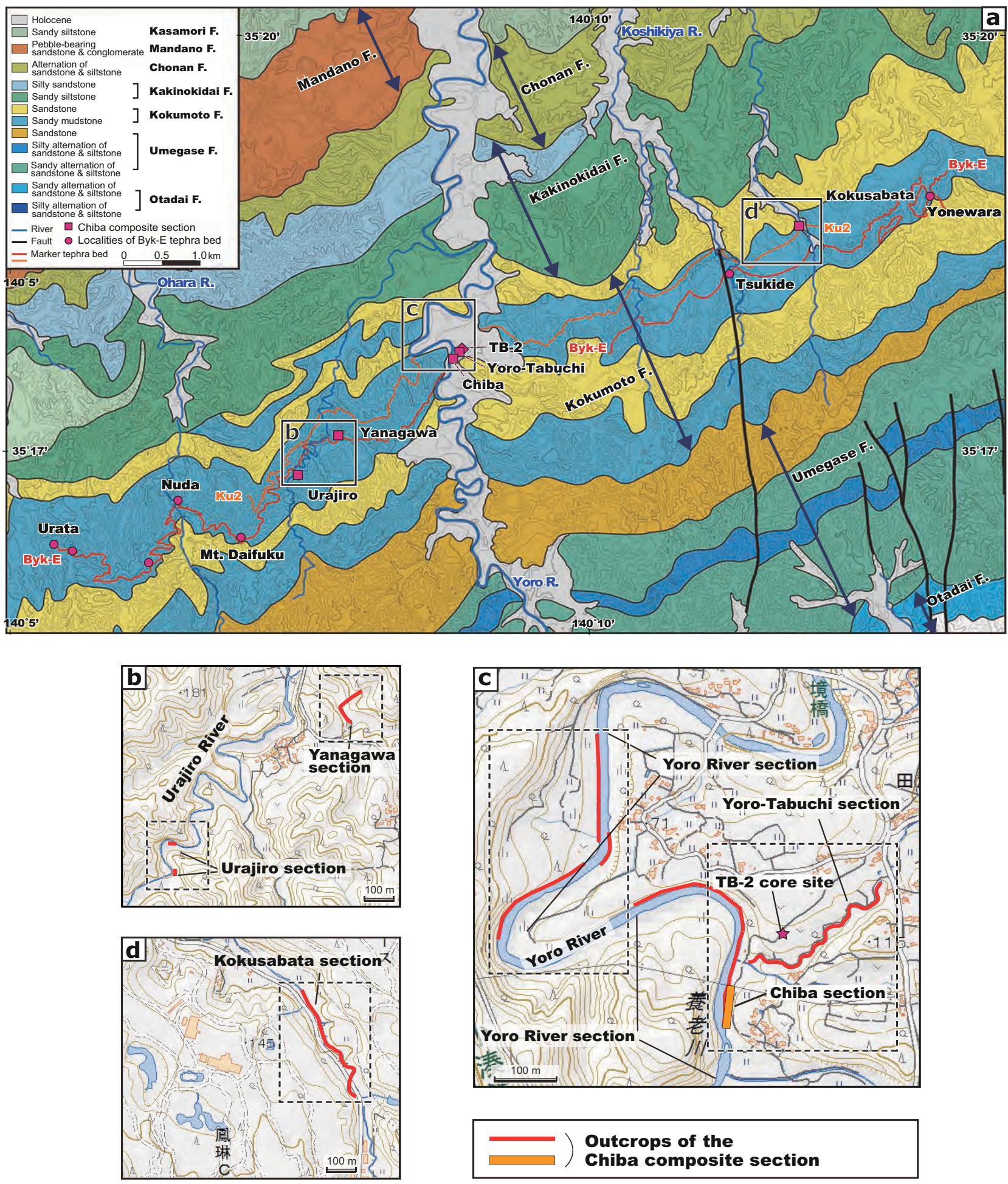

Figure 8. (a) Geological map of the central part of the Boso Peninsula and location of the Chiba composite section (Yoro River [including Chiba], Yoro-Tabuchi, Yanagawa, Urajiro, and Kokusabata sections), modified from Mitsunashi et al. (1961) and Nirei et al. (1989). The marker tephra beds, Ku2 and Byk-E, are shown on the map. (b)-(d): Topographic maps for individual sections of the Chiba composite section (red) and Chiba section along the Yoro River (orange). All sampling locations for individual sections of the Chiba composite section are shown in Supplementary Fig. 1. Dashed boxes correspond to detailed maps for all sampling locations from the Chiba composite section (Figure S1)

at the GSSP level (Figs. 15 and 16), potentially facilitating regional climatostratigraphic correlation of the boundary.

\section{Calcareous Nannofossils}

Well-preserved, abundant nannofossils representing at least 15 genera 


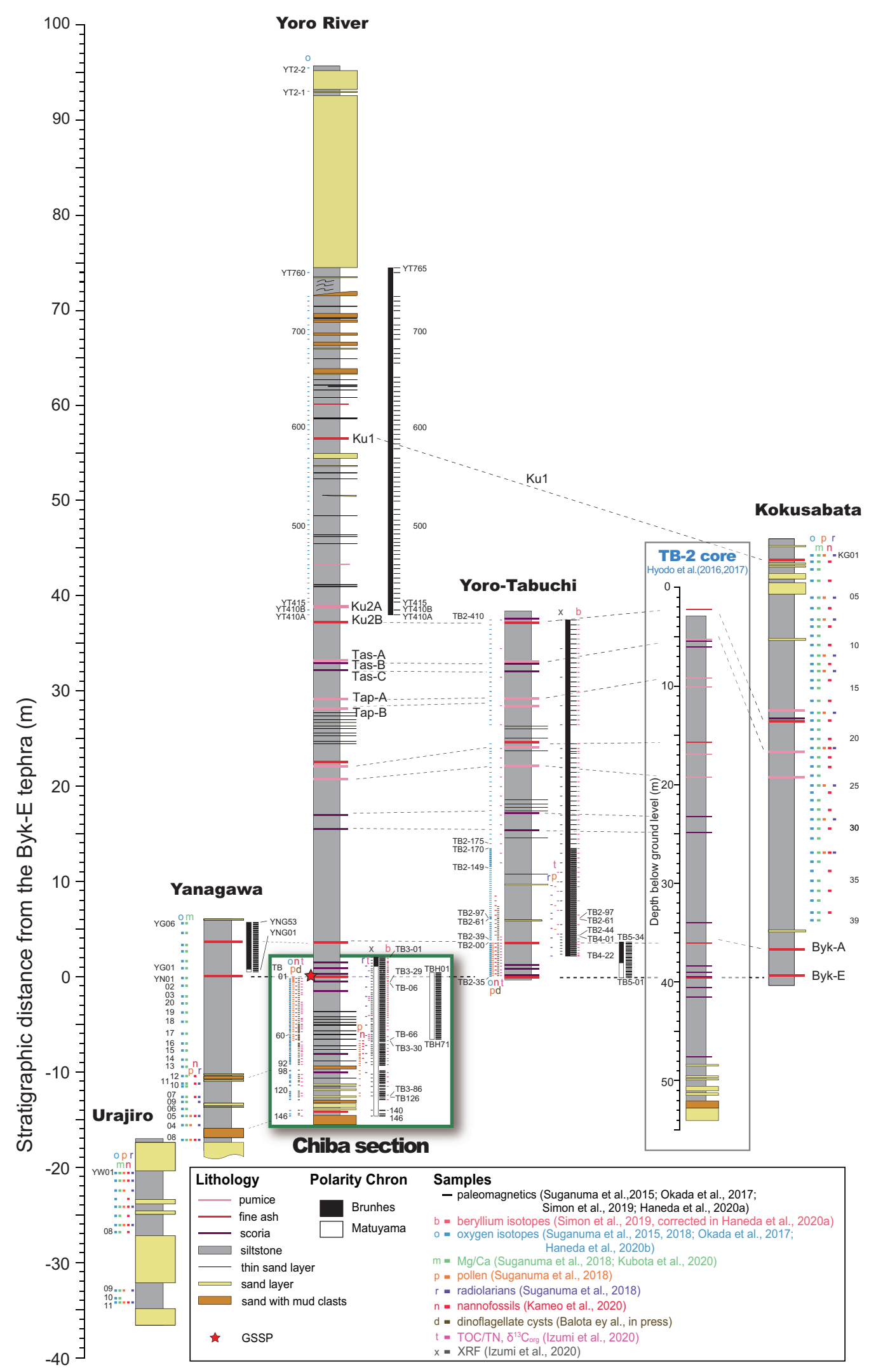

Figure 9. Detailed stratigraphic correlations of the Chiba composite section between the Urajiro, Yanagawa, Yoro River (including Chiba section and GSSP), Yoro-Tabuchi, and Kokusabata sections in comparison with the TB-2 core from near the Chiba and Yoro-Tabuchi sections (Hyodo et al., 2016; 2017). The stratigraphic correlations are based on lithological changes and numerous tephra beds. Sampling horizons for paleomagnetic, authigenic ${ }^{10} \mathrm{Be} / \mathrm{Be}$, oxygen isotope $\left(\delta^{18} \mathrm{O}\right)$, pollen, marine microfossils (calcareous nannofossils, radiolarians, and dinoflagellate cysts), and other geochemical analyses (Mg/Ca, TOC/TN, organic carbon isotope, and XRF) for previous studies (Suganuma et al., 2015, 2018; Okada et al., 2017; Simon et al., 2019; Haneda et al., 2020a and b; Balota et al., in press; Izumi et al., 2020; Kubota et al., 2020; Kameo et al., 2020) are shown in the figure. 

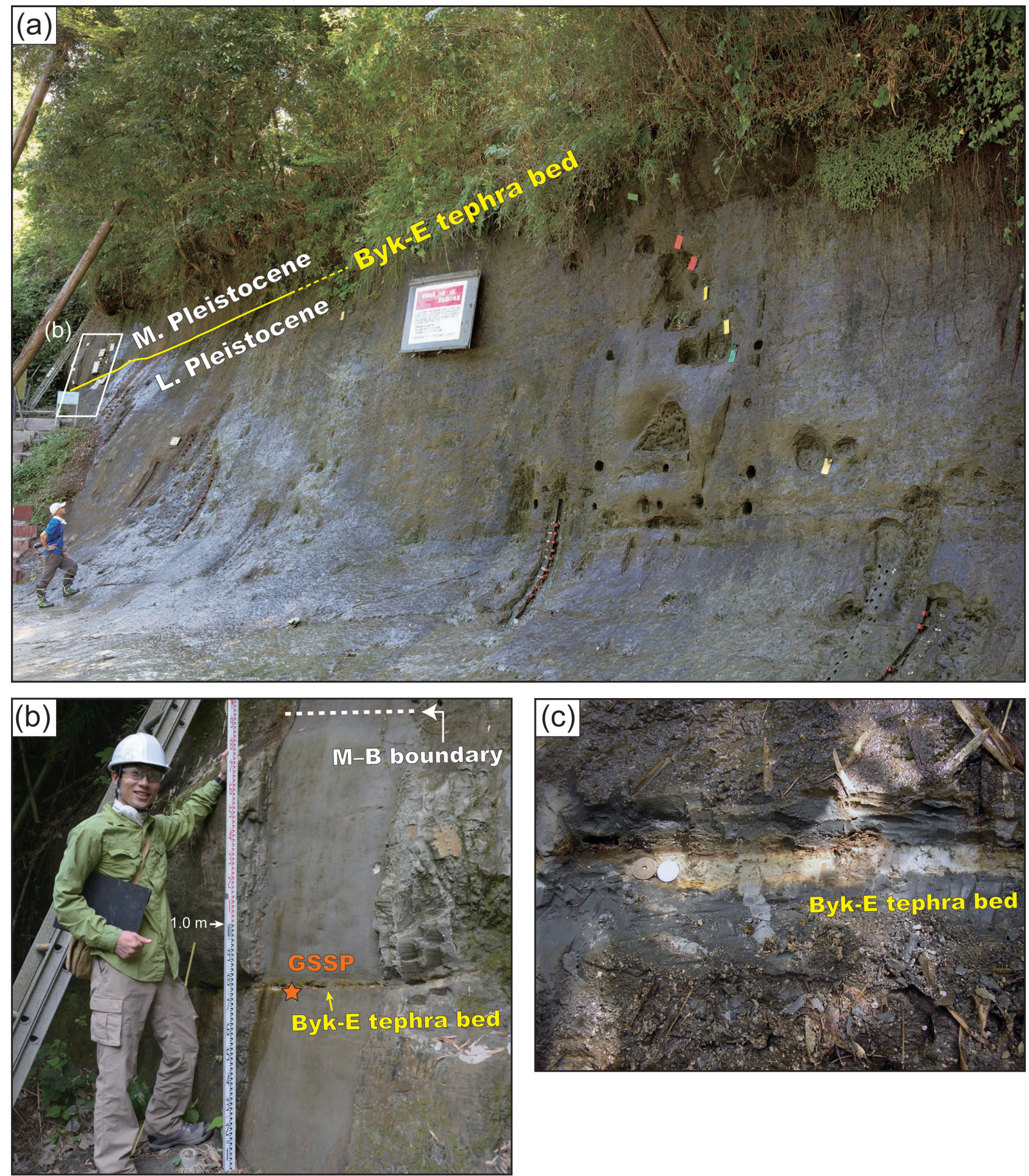

Figure 10. Lithofacies across the Lower-Middle Pleistocene boundary in the Chiba section, the site of the GSSP. (a) Overview of the Chiba section. The yellow line indicates the Byk-E tephra bed and GSSP horizon. (b) and (c) Details of the Byk-E tephra bed. The length of rule (b) and diameter of the coin (c) are $2.0 \mathrm{~m}$ and $2 \mathrm{~cm}$, respectively. The GSSP (orange star) is located at the base of the Byk-E tephra bed in (b).

and 27 species have been recorded throughout the Kazusa Group (Sato et al., 1988; 1999) (Fig. 5), allowing 10 Pleistocene nannofossil biohorizons to be recognized between 2.06 and 0.89 Ma (e.g., Matsuoka and Okada, 1990; Sato and Takayama, 1992; Raffi et al., 1993; Suganuma et al., 2018; Fig. 5). The uppermost horizon examined by Sato et al. (1988) is in the middle of the Kasamori Formation, which is considered to be below the $\mathrm{LAD}$ (last appearance datum: equivalent to highest occurrence datum) of Pseudoemiliania lacunosa (0.433 \pm 0.020 Ma in the Ontong Java Plateau, Berger et al., 1994; 0.44 Ma in the eastern equatorial Pacific, Anthonissen and Ogg, 2012).

Within the Chiba composite section (Suganuma et al., 2018; Kameo et al., 2020; Fig. 5), no reliable biohorizons were detected owing to the short duration represented. However, fewer occurrences of mediumsized specimens (4-5 $\mu \mathrm{m})$ and the temporary absence of larger specimens $(\geq 5 \mu \mathrm{m})$ in MIS 19a may correspond to the highest occurrence of the larger form of Gephyrocapsa sp. C recognised by Matsuoka and Okada (1990). This horizon might alternatively coincide with td2 (Maiorano and Marino, 2004), one of two temporary disappearances 


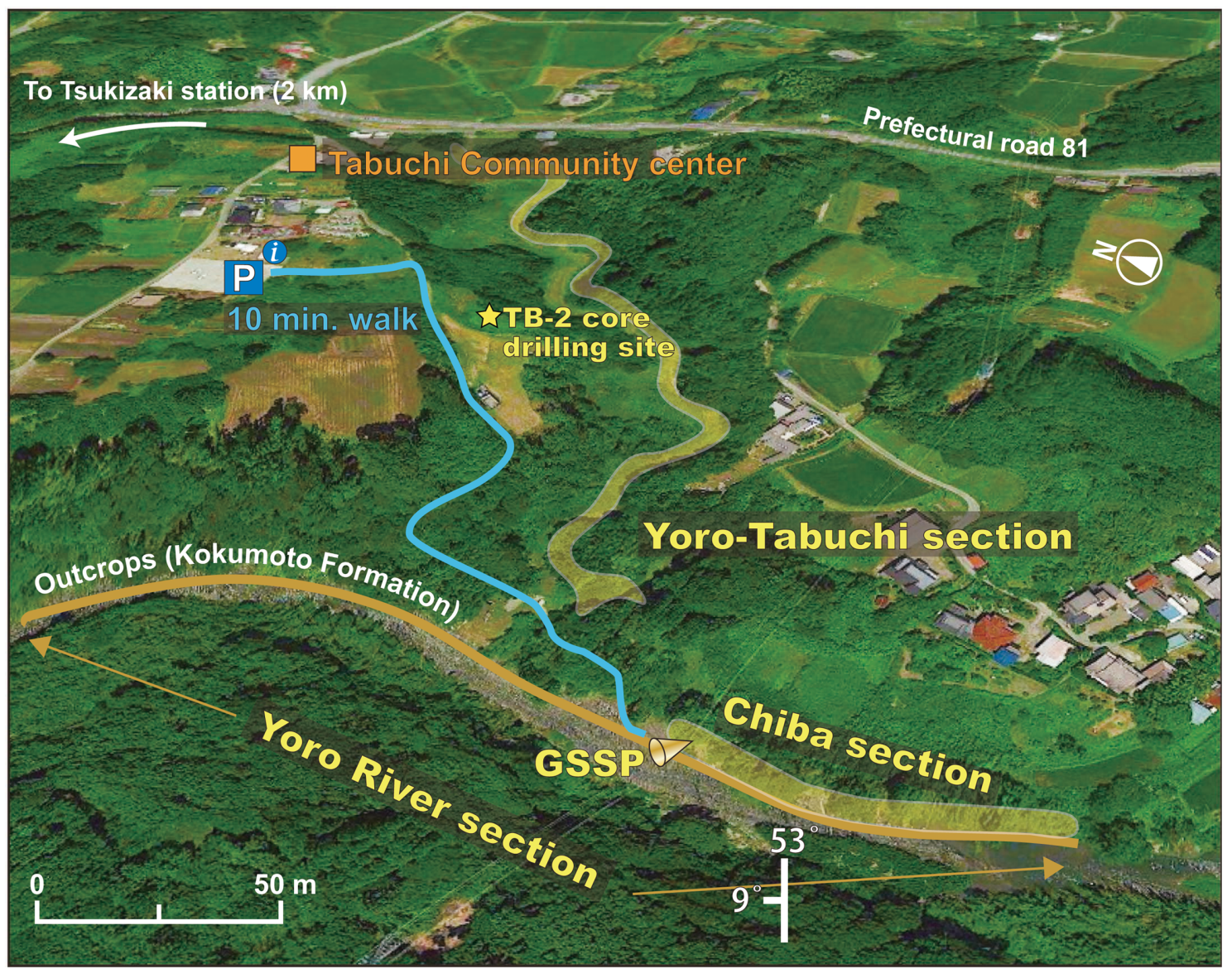

Figure 11. Access to the Chiba section and GSSP from the Tabuchi district. The Yoro-Tabuchi section (part of the Chiba composite section) is also shown. A yellow star shows the drilling site for the TB-2 core (Hyodo et al., 2016).

of Gephyrocapsa omega. This biohorizon was found at the Mediterranean ODP Sites 964, 967, and 977, and the North Atlantic DSDP Site 607, although it seems to be diachronous (Maiorano and Marino, 2004).

\section{Diatoms}

Diatoms from the Kazusa Group along the Yoro River were studied by Cherepanova et al. (2002) who recognised mainly marine taxa with subordinate fresh water and sublittoral species, and determined seven biohorizons estimated from 1.00 to $0.53 \mathrm{Ma}$ (Fig. 5). A diatom analysis for the TB-2 core by Tanaka et al. (2017) yielded 70 diatom taxa from a total of 68 horizons in the 50-meter drilled section, including a detailed characterization of MIS 19.

\section{Planktonic foraminifera}

The detailed stratigraphic distributions of six planktonic foraminiferal index species were determined in studies by Oda $(1977,1979)$, Igarashi $(1994,1996)$, Suganuma et al. (2018), and Shikoku et al. (in revision) (Fig. 5). Of these, the highest occurrence (HO) of Neogloboquadrina inglei (712 ka; Kucera and Kennett, 2000) is the most notable because this biohorizon lies just below the upper boundary of the Kokumoto Formation (Shikoku et al., in revision).

Paleoenviromental analysis based on planktonic foraminiferal assemblages of the Kazusa Group along the Yoro River reflect a shift from the influence of the Tsugaru Warm Current to that of the Kuroshio Current (with subsurface cold water originating from the Oyashio Current) after 770 ka (Suganuma et al., 2018; Shikoku et al., in revision).

\section{Benthic foraminifera}

Assemblages from the Chiba composite section are characterized by the dominant occurrence of bathyal species with the inclusion of some sublittoral species (Kamemaru, 1996). Our preliminary observations similarly show the benthic foraminifera to be characterized by dominant bathyal species, with sublittoral species being rare. Kamemaru (1996) estimated relatively shallow depositional environments for the Kokumoto Formation based on the presence of sublittoral species, but downslope transport is a more likely explanation for these rare specimens.

\section{Radiolaria}

Radiolarian assemblages from the Chiba composite section reflect the mixing of Kuroshio and Oyashio waters. The radiolarian sea-surface temperature index, the $\operatorname{Tr}$ value, fluctuates considerably between 0.2 and 0.8 through the examined interval (Figs. $3 \mathrm{k}$ and 17), and the several maxima and minima recorded likely reflect oscillations of the 

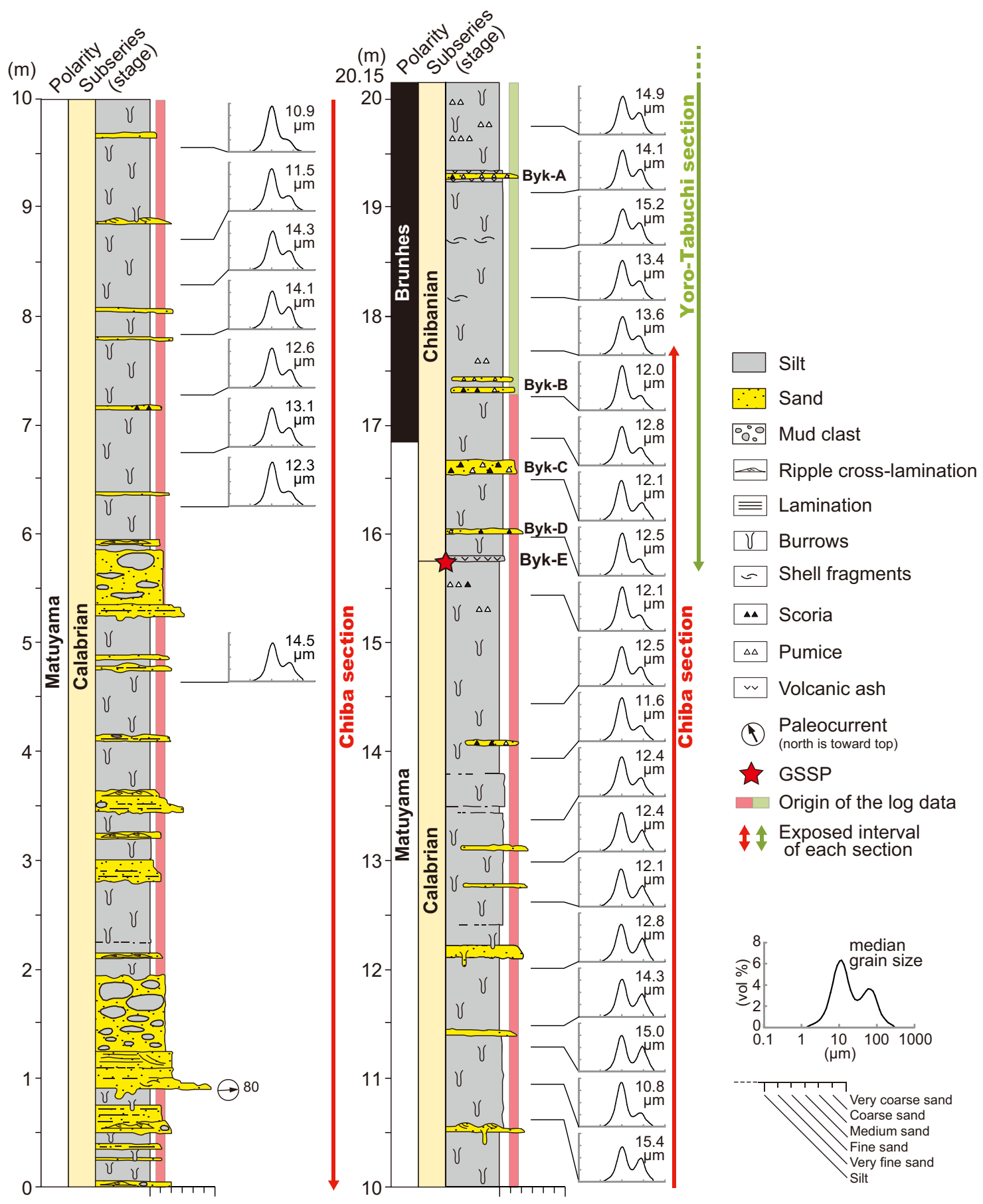

Figure 12. Detailed stratigraphic log of the Chiba and Yoro-Tabuchi sections and results of grain-size analyses of silty beds (after Nishida et al., 2016). The length scale of the log is based on Nishida et al. (2016).

Kuroshio Current. This pattern is consistent with millennial-scale hydrographic changes in the northwestern Pacific revealed by the ultra-highresolution $\delta^{18} \mathrm{O}$ record from planktonic foraminifera (Haneda et al., 2020b).

Cycladophora davisiana is a known indicator of cold intermediate water (e.g., Itaki and Ikehara, 2004) and tends to increase in relative abundance in MIS 19b and 18. Carpocanarium papillosum, Cornutella profunda and Cyrtopela languncula, which are also known to be deep dwelling species (e.g., Tanaka and Takahashi, 2008), occur spo- radically in the section. The presence of these deep dwellers suggests that the depositional depth of the Chiba composite section was greater than upper bathyal.

Total concentrations show higher values during MIS 19c (Fig. 17). Because radiolarians represent both consumers and secondary producers (many possessing algal symbionts) in the oceans, their high abundance likely relates to higher biological productivity in the surface waters. This pattern seems consistent with geochemical proxies such as $\delta^{13} \mathrm{C}_{\text {org }}$ and the $\mathrm{Ca} / \mathrm{Ti}$ ratio. 


\section{Dinoflagellate Cysts}

Dinoflagellate cysts were analysed from 792 to $770 \mathrm{ka}$ (the top of MIS 20, just below termination IX, to MIS 19b) using the same sample set collected for pollen analysis, with a typical sample spacing of $\sim 20 \mathrm{~cm}$ (=225 years) (Fig. 9). Approximately, thirty-one dinoflagellate cyst taxa were recorded (Balota et al., in press). The early part of MIS 19c is characterized by a decline in heterotrophic species, suggesting a progressive reduction in productivity and nutrient levels. A rise in Lingulodinium machaerophorum at $781 \mathrm{ka}$, reaching a peak at 780 $\mathrm{ka}$, coincides with a brief but prominent drop in broadleaved trees in the middle of MIS 19c (Balota et al., in press). At 773.1-772.8 ka (0.95-1.15 $\mathrm{m}$ above the Byk-E tephra bed), an abrupt and sustained rise to dominance of the cysts of Protoceratium reticulatum and corresponding significant increase in cyst concentrations (Fig. 3h) imply the arrival of cooler and more biologically productive sururface waters. This is interpreted as marking the influence of the Kuroshio-Oyashio interfrontal zone resulting from a southward shift in the Kuroshio Extension Current (Balota et al., in press).

\section{Matuyama-Brunhes Boundary}

The M-B boundary in the Chiba composite section and its detailed geomagnetic behavior have been reported in several pioneering studies (e.g., Niitsuma, 1971; Okada and Niitsuma, 1989; Aida, 1997). These studies used only alternating field demagnetization techniques, and considered the M-B boundary to be $1-2 \mathrm{~m}$ below the Byk-E tephra bed. Suganuma et al. (2015) applied thermal demagnetization to their samples, and found that earlier studies had not entirely removed the overprint on the primary magnetic signals. These authors concluded that the M-B boundary horizon is located approximately $0.8 \mathrm{~m}$ above the Byk-E tephra bed in the Yanagawa section (Fig. 13).

Okada et al. (2017) and Haneda et al. (2020a) subsequently reported high-resolution paleomagnetic results from the Chiba composite section, and defined the directional midpoint of the M-B boundary at 1.1 $\mathrm{m}$ above the Byk-E tephra bed in the Chiba section (Figs. 9 and 13), which compares with the results of Suganuma et al. (2015). Okada et al. (2017) reported a very detailed virtual geomagnetic pole (VGP) path from this section at $10-\mathrm{cm}$ resolution across the boundary (Fig. 4). The directional transition zone from a reversed polarity (VGP latitude $<-45^{\circ}$ ) to a normal polarity (VGP latitude $>+45^{\circ}$ ) lies between $0.35 \mathrm{~m}$ and $1.85 \mathrm{~m}$ spanning ca. $1.7 \mathrm{kyr}$ based on the age model of Suganuma et al. (2018) (Okada et al., 2017; Haneda et al., 2020a), and likely corresponds to the "polarity switch" of the M-B boundary (Valet et al., 2012). The horizon of the M-B boundary in the Chiba section is nearly identical with that shown in a core (TB-2) from the vicinity of this section (Hyodo et al., 2016) and a newly obtained high-resolution paleomagnetic record from the lowermost part of the Yoro-Tabuchi section (Fig. 13) (Haneda et al., 2020a). These results confirm the existence and continuity of the M-B boundary in the Chiba composite section in several distinct sections and by different research groups.

The M-B boundary in the Chiba section has an astronomically estimated age of $\sim 772.9 \mathrm{ka}$, which is consistent with astronomically tuned paleomagnetic records (e.g., Channell et al., 2010; Channell, 2017; Valet et al., 2019), and cosmogenic nuclide records (Raisbeck et al., 2006; Suganuma et al., 2010; Simon et al., 2018a; Valet et al., 2019). This age is consistent also with a recalculated radiometric age for the M-B boundary of $771.7 \pm 7.3 \mathrm{ka}$ using the U-Pb zircon age of the Byk-E

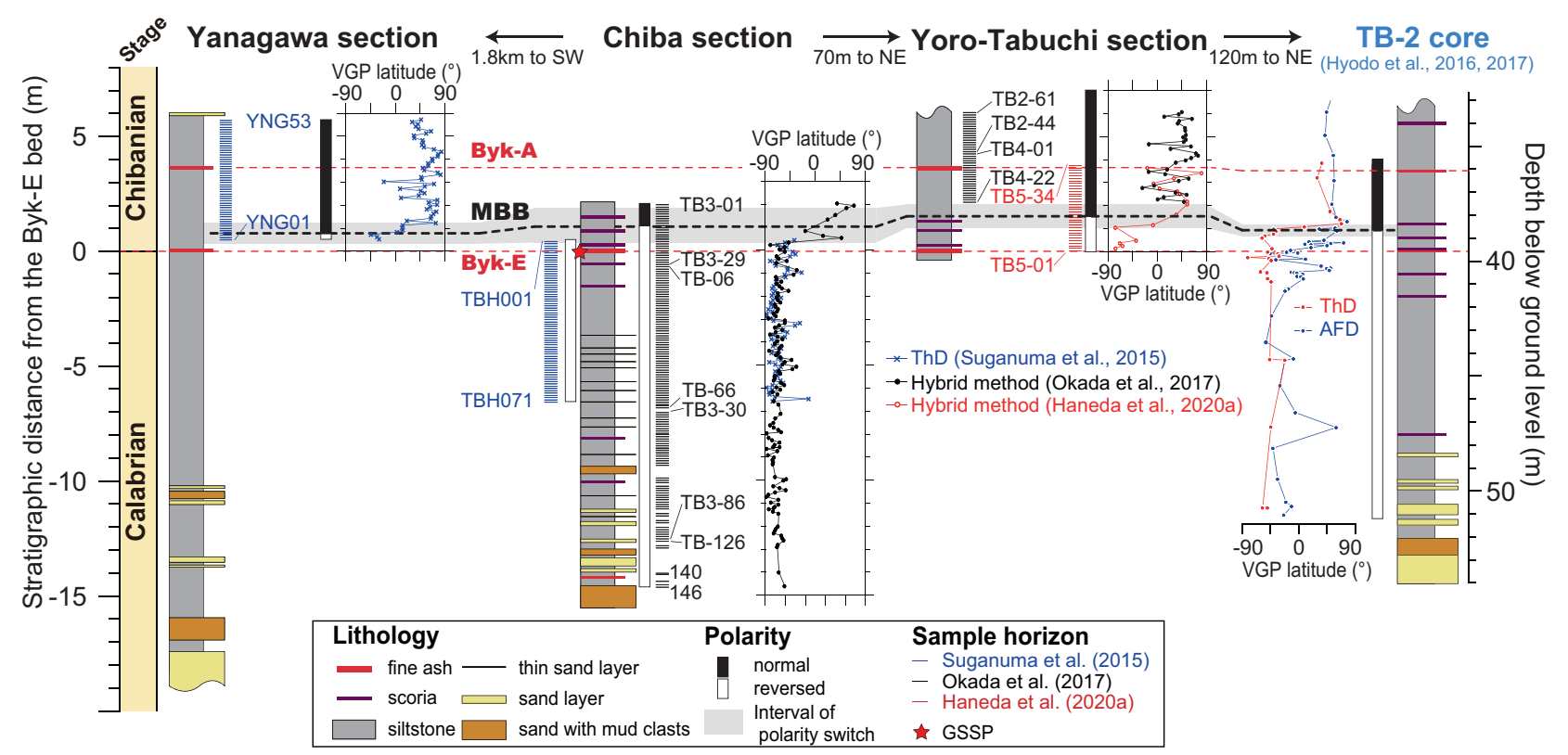

Figure 13. Detailed stratigraphic correlation along the Chiba (GSSP location), Yoro-Tabuchi, Yanagawa sections, and TB-2 core. VGP (virtual geomagnetic pole) latitudes based on ThD (thermal demagnetization) in Suganuma et al. (2015) are shown by blue crosses. VGP latitudes based on the hybrid method (ThD followed by AFD: alternating field demagnetization) are marked by closed black and open red circles and lines (Okada et al., 2017; Haneda et al., 2020a). TB-2 sediment core was drilled at 190 m northeast of the Chiba section, and VGPs obtained from this core in Hyodo et al. (2016) are shown by closed blue circles and lines (AFD) and closed red circles and lines (ThD). Horizontal blue, black, and red bars indicate sampling horizons. Horizontal dashed black and red lines show respectively the midpoint of the directional transition zone of Matuyama-Brunhes geomagnetic reversal, and the tephra beds. 


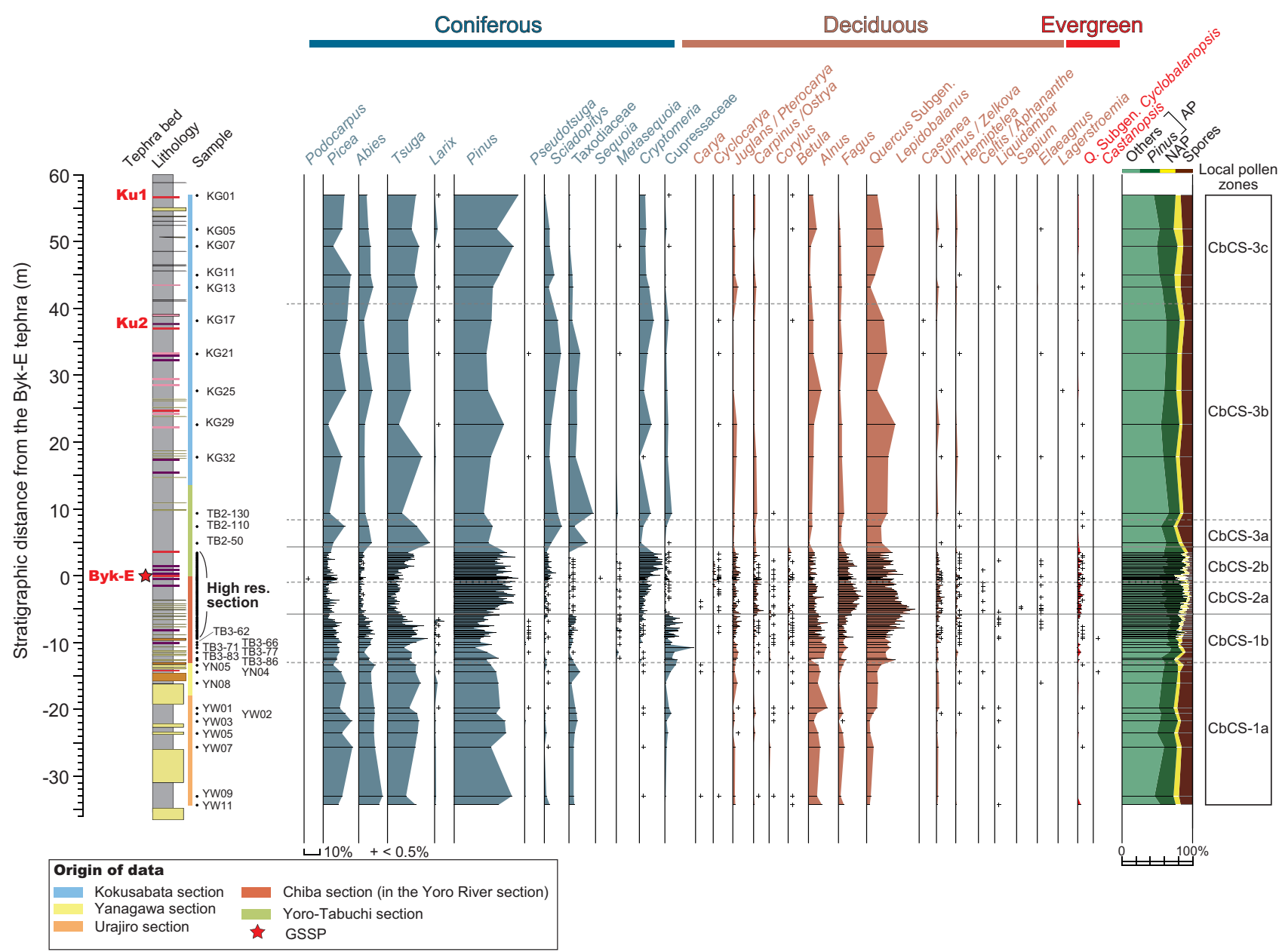

Figure 14. Percentage pollen diagram for the Chiba composite section plotted against depth (replotted from Suganuma et al., 2018). The pollen sum for percentage calculations consists of the total arboreal pollen (AP) dominated by Pinus, with non-arboreal pollen (NAP) and pteridophyte and bryophyte spores excluded. Cumulative frequencies of AP, NAP and spores are also summarized. Sections sampled for palynological analyses are indicated by color bars.

tephra bed (Suganuma et al., 2015) and its astronomical age model (Suganuma et al., 2018), and with a weighted mean ${ }^{40} \mathrm{Ar} /{ }^{39} \mathrm{Ar}$ age of $773 \pm 2 \mathrm{ka}$ from new measurements and the recalibration of all M-B transitionally-magnetized lava flow sequences (Singer et al., 2019) (Fig. 4; Supplementary Fig. 2).

A high-resolution relative paleointensity (RPI) signal has also been obtained (Fig. 2; Okada et al., 2017; Simon et al., 2019; Haneda et al., 2020a) and, together with the authigenic ${ }^{10} \mathrm{Be} /{ }^{\beta} \mathrm{Be}$ ratio record discussed below, serves as a proxy for the geomagnetic field intensity.

The Chiba composite section has one of the most detailed marine sedimentary records known for the M-B geomagnetic reversal (Haneda et al., 2020a). Owing to, inter alia, exceptionally high sedimentation rates, it is a key section for understanding the dynamics of the geomagnetic dynamo and for calibrating the geological time scale.

\section{Tephrostratigraphy}

\section{Byk-E Tephra Bed}

The Ontake-Byakubi-E tephra, better known by its abbreviation Byk-E, is the most conspicuous and useful marker bed for the Lower-Middle Pleistocene boundary in the Kazusa Group, being widely distributed in the central part of the Boso Peninsula (Okada and Niitsuma, 1989; Kazaoka et al., 2015; Nanayama et al., 2016). In the Chiba composite section, it is a white pumiceous fine ash deposit $1.0-5.0 \mathrm{~cm}$ thick, sandwiched between dark gray sandy silt beds (or layers) (Fig. 10). Based on its lithofacies, mineralogy, and stratigraphic relationships with other tephra beds, the Byk-E tephra is correlated with the YUT5 bed erupted from the Older Ontake volcano at Mount Ontake (Takeshita et al., 2016), an active volcano in the central part of the Japanese archipelago. The Byk-E tephra bed rests smoothly over the silty sediments, as would be expected from a fall-out deposit, and is partially disturbed by subsequent bioturbation. There is no indication of a hiatus. The Byk-E tephra bed, and hence the GSSP, has an astronomically estimated age of $774.1 \mathrm{ka}$. Suganuma et al. (2015) presented a $\mathrm{U}-\mathrm{Pb}$ zircon age of $772.7 \pm 7.2 \mathrm{ka}$ for the eruption/deposition age of the Byk-E tephra, which is consistent with its astronomically estimated age (774.1 ka).

Because the Byk-E tephra bed is located almost at the base of the directional transition zone of the M-B geomagnetic reversal (the midpoint of which has an astronomically estimated age of $\sim 772.9 \mathrm{ka}$ ), it 


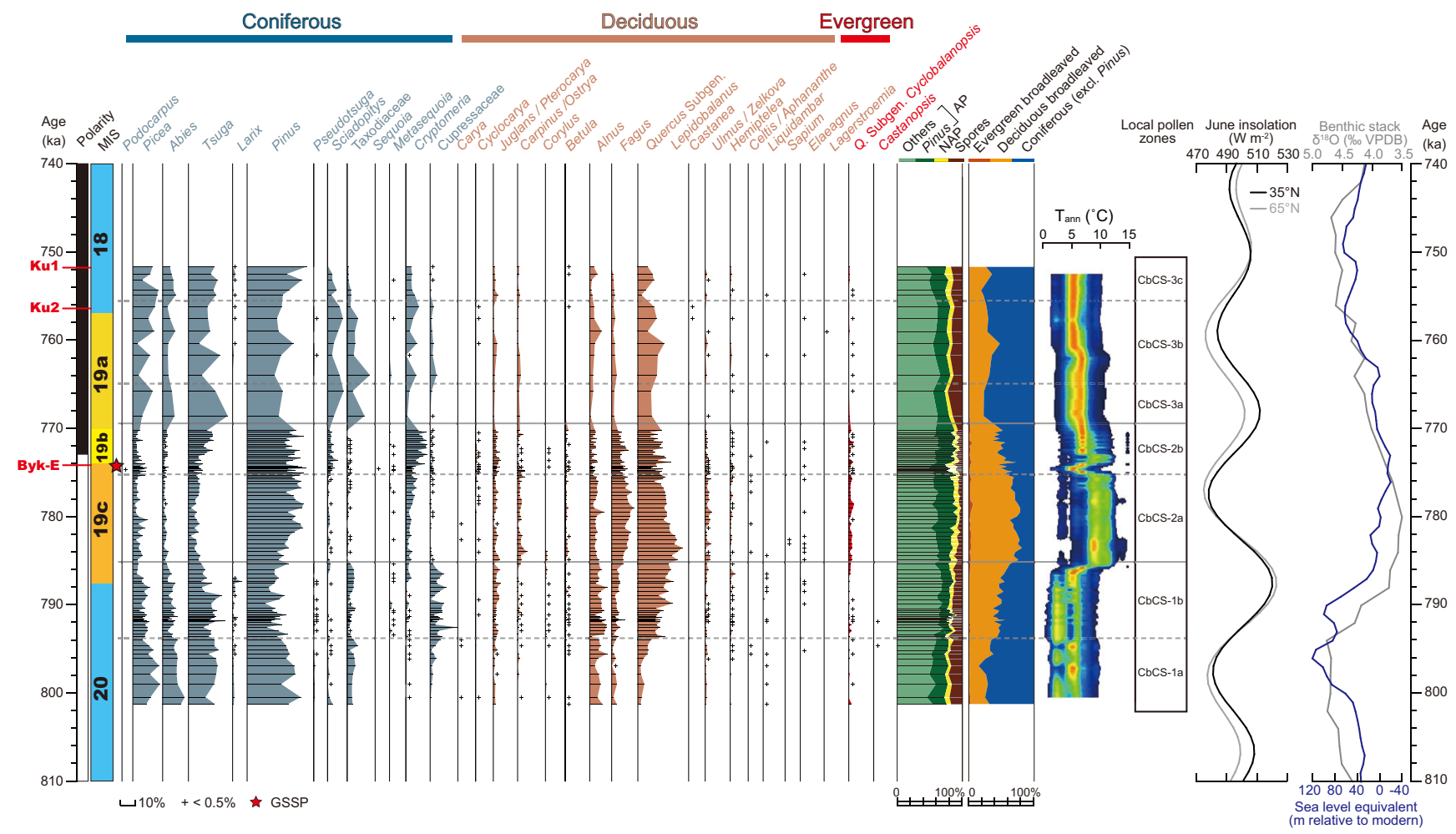

Figure 15. Percentage pollen diagram for the Chiba composite section plotted against time (Suganuma et al., 2018). See Figure 14 for explanation. The arboreal pollen is further subdivided into evergreen broadleaved trees, deciduous broadleaved trees and coniferous trees (excluding Pinus), with the ratio between the combined broadleaved pollen and the total tree pollen excluding Pinus ("broadleaved/AP") employed as a substitutional temperature proxy. Quantified variations in the mean annual temperature $\left(T_{a n n}\right)$ are based on the modern analogue technique (Nakagawa et al., 2002), converting the fossil pollen spectra using the modern surface pollen dataset covering the Japanese archipelago (Gotanda et al., 2002) and the multiple regression analytical software Polygon 2.4.4. Pinus is excluded from the both fossil and surface pollen datasets for MAT calculation, because of the over-representation of Pinus pollen in distal marine environments (Heusser, 1990; Okuda et al., 2006). The LR04 benthic stack (Lisiecki and Raymo, 2005), the eustatic curve of Elderfield et al. (2012), and $65^{\circ} \mathrm{N}$ and $35^{\circ} \mathrm{N}$ June insolation curves (Laskar et al., 2004) are shown for comparison.

serves as an exceptional stratigraphic marker for the M-B boundary both at the outcrop and regionally (Figs. 8-10 and 13).

\section{Other Key Tephra Beds}

Several sets of tephra beds are recognised in the Chiba composite section (Kazaoka et al., 2015; Nishida et al., 2016; Suganuma et al., 2018) (Fig. 9). Byk represents a set of five individual tephra beds, including the Byk-E tephra bed mentioned above. Tas $(\mathrm{A}-\mathrm{C})$ and Tap (A and $\mathrm{B}$ ) tephra beds are located within thick and massive silty beds in the upper part of the Chiba composite section (Kazaoka et al., 2015). As noted above, these very detailed tephrostratigraphic data further underpin the high-resolution stratigraphic correlation within the Chiba composite section, and enable an integrated stratigraphy to be developed for the succession (Fig. 9).

\section{Chemostratigraphy}

\section{Oxygen Isotope $\left(\delta^{I 8} \mathrm{O}\right)$ Stratigraphy}

Benthic and planktonic foraminiferal $\delta^{18} \mathrm{O}$ stratigraphy from late MIS 20 to early MIS 18 (Fig. 16) provides the age control for the Chiba composite section. The Yoro River (including the Chiba section which contains the GSSP) and Yoro-Tabuchi sections were analysed at ultrahigh stratigraphic resolution with an average sample spacing as high as $10 \mathrm{~cm}$, which corresponds to approximately 140 years (shortest interval 30 years). The Yanagawa, Urajiro, and Kokusabata sections were sampled at the lower resolution of $100 \mathrm{~cm}$ (approximately 660 years) on average (Suganuma et al., 2015, 2018; Okada et al., 2017; Haneda et al. 2020b).

The $\delta^{18} \mathrm{O}$ records of the planktonic foraminifera Globigerina bulloides and G. inflata $\left(\delta^{18} \mathrm{O}_{\text {plank }}\right)$ from the Chiba composite section are generally similar to the benthic $\delta^{18} \mathrm{O}$ records, showing glacial-interglacial cycles from late MIS 20 to early MIS 18 (Fig. 17). The high cross-correlation coefficients between benthic and planktonic $\delta^{18} \mathrm{O}$ records support this interpretation ( $G$. inflata: $\mathrm{r}=0.87$; vs. G. bulloides: $\mathrm{r}=0.75$ ). In detail, multi-millennial- to millennial-scale changes are also found in both $\delta^{18} \mathrm{O}_{\text {plank }}$ records, not only in the later part of the MIS 19 but also during Termination IX. Because the amplitudes of these $\delta^{18} \mathrm{O}_{\text {plank }}$ variations are apparently larger than those of the benthic $\delta^{18} \mathrm{O}$ record, fluctuations in surface-subsurface temperature/salinity are suggested for these intervals. The latitudinal temperature gradient in the northwestern Pacific Ocean is significant at present (Figs. 1a and 1b), whereas salinity variations in the northwestern Pacific Ocean are small (Haneda et al., 2020b). This implies that the $\delta^{18} \mathrm{O}_{\text {plank }}$ records mostly 


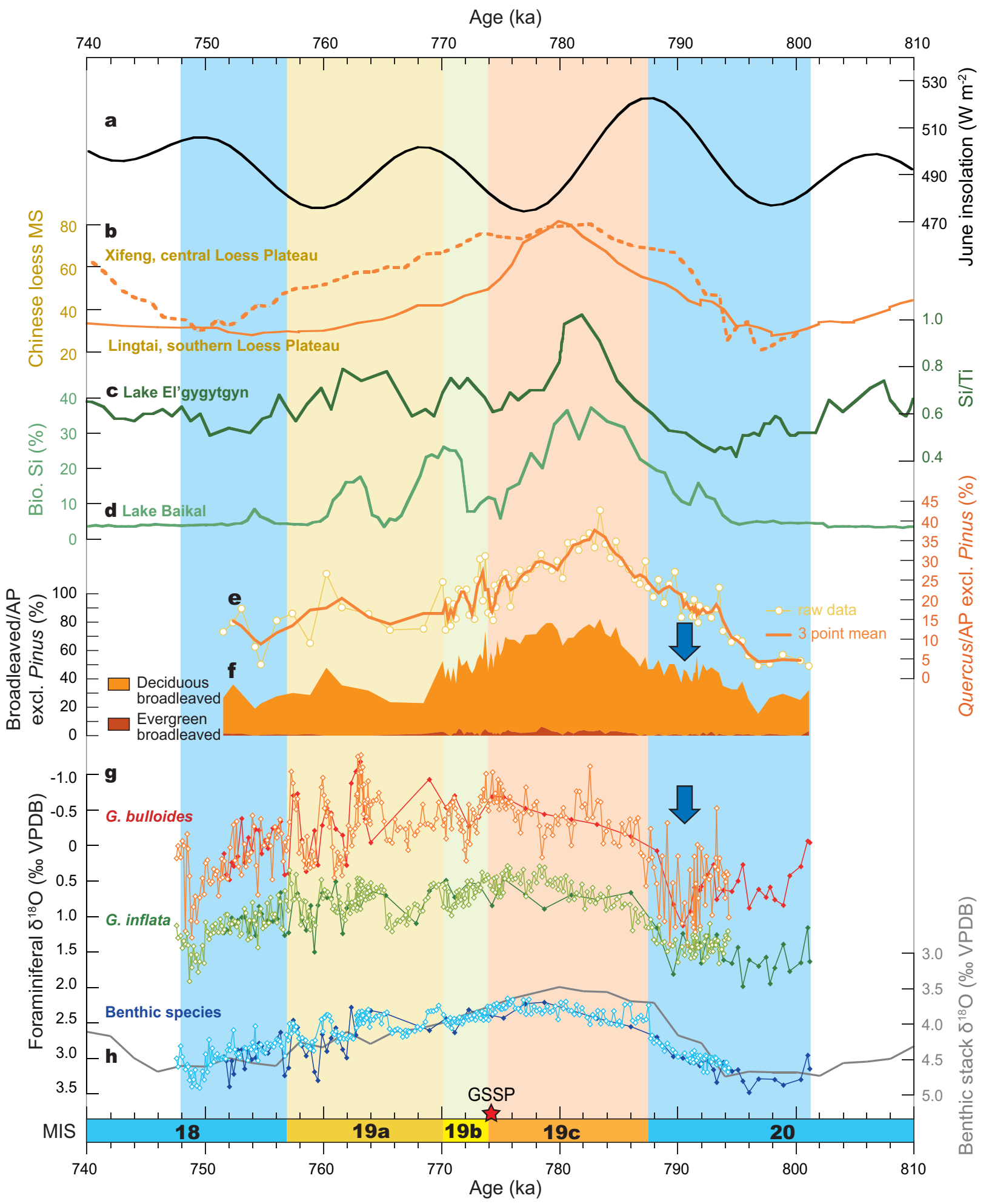

Figure 16. Paleoclimatic changes from MIS 20 to MIS 18 (modified and corrected from Suganuma et al., 2018). (a) $65^{\circ} \mathrm{N}$ insolation in June (Laskar et al., 2004). (b) Magnetic susceptibility (MS) from the Xifeng section of the central Chinese Loess Plateau (Guo et al., 2009), and Lingtai section of the southern Chinese Loess Plateau (Sun et al., 2010). (c) XRF core scanning-derived Si/Ti ratio from Lake El'gygytgyn (Wennrich et al., 2014). (d) Biogenic silica contents from Lake Baikal (Prokopenko et al., 2006). (e) and (f) Percentages of Quercus subgen. Lepidobalanus (\%), and evergreen broadleaved trees and deciduous broadleaved trees relative to the total AP excluding Pinus (Suganuma et al., 2018). (g) Planktonic and benthic foraminiferal oxygen isotope $\left(\delta^{18} \mathrm{O}\right)$ stratigraphy (Suganuma et al., 2015; Okada et al., 2017; Suganuma et al., 2018; Haneda et al., 2020b). The red/dark-green/dark-blue lines with solid diamonds are from the Yanagawa, Urajiro and Kokusabata sections, respectively (1.0 $\mathrm{m}$ spacing), and orange/light-green/light-blue lines with open diamonds are from the Yoro River and Yoro-Tabuchi sections (0.1 to $0.5 \mathrm{~m}$ spacing). (h) The LR04 benthic stack (Lisiecki and Raymo, 2005). Suggested position of the Younger Dryas-type cooling event is shown by blue arrows. 
reflect surface ( $<50 \mathrm{~m}$, G. bulloides) and subsurface ( $>100 \mathrm{~m}, \mathrm{G}$. inflata) temperature changes in this region. The $\delta^{18} \mathrm{O}$ records from $G$. bulloides and G. inflata are relatively constant through MIS 19, except during Termination IX and the later part of MIS 19. Significant surface and subsurface temperature changes are recognised during the beginning of Termination IX, which is thought to correspond to a Younger Dryas-type cooling event. During the later part of MIS 19, the surface and subsurface temperatures were likely to have been higher than for other intervals of MIS 19. These may be explained by dynamic oceanographic changes in the surface-subsurface of the northwestern Pacific Ocean during Termination IX and the later part of MIS 19.

\section{Mg/Ca Paleotemperature Records}

$\mathrm{Mg} / \mathrm{Ca}$ paleotemperature records for $G$. inflata (Suganuma et al., 2018) and for G. bulloides (Kubota et al., in press) are available for the Chiba composite section based on samples from the Yanagawa, Urajiro and Kokusabata sections (Fig. 17 for $G$ inflata). The $\mathrm{Mg} / \mathrm{Ca}$ temperature of $G$. inflata $\left(\mathrm{T}_{\mathrm{inf}}\right)$, using the conversion of Anand et al. (2003), is regarded as reflecting the subsurface winter temperature $(>100 \mathrm{~m})$. The average $T_{\text {inf }}$ from late MIS 20 to early MIS 18 is ca. $17^{\circ} \mathrm{C}$, showing millennial scale variations superimposed on orbital scale variations of the glacial-interglacial cycle. On an orbital scale, the temporal variations show relatively higher winter temperatures from the end of Termination IX to MIS 19c, and lower winter temperatures in the later part of MIS 19. In addition, $T_{\text {inf }}$ reveals millennial scale fluctuations including several spikes of high and low values during Termination IX. In contrast, the $\mathrm{Mg} / \mathrm{Ca}$ temperature of $\mathrm{G}$. bulloides shows relatively high values $\left(\sim 19^{\circ} \mathrm{C}\right)$ from late MIS $19 \mathrm{c}$ to MIS 18 (Kubota et al., in press).

\section{Organic Carbon Isotope, C/N Ratio and XRF}

The $\mathrm{C} / \mathrm{N}$ ratio (= total organic carbon: TOC vs. total nitrogen: TN) and stable organic carbon isotope $\left(\delta^{13} \mathrm{C}_{\text {org }}\right)$ values obtained from the Chiba composite section also show excellent regional paleoclimatic and paleoenvironmental records from late MIS 18 to early MIS 20 (Fig. 17). The lower $\delta^{13} \mathrm{C}_{\text {org }}$ and $\mathrm{C} / \mathrm{N}$ values during MIS $19 \mathrm{c}$ are most likely caused by a lower input of terrestrial material and/or higher biogenic productivity. The $\mathrm{Ca} / \mathrm{Ti}$ ratios, obtained by X-ray fluorescence spectrometry (XRF) analysis for the same interval, also show higher values during MIS 19c, suggesting the lower input of terrestrial material and/or higher biogenic productivity (Izumi et al., 2020). These phenomena are consistent with the paleoceanographic settings reflected in the microfossil records and the depositional setting of the Chiba composite section.

\section{Cosmogenic Nuclide Record}

A total of 122 samples from the Chiba and Yoro-Tabuchi sections were analysed for their authigenic ${ }^{10} \mathrm{Be} /{ }^{9} \mathrm{Be}$ ratio over a $\sim 53 \mathrm{~m}$ interval that extends from 794 to $756 \mathrm{ka}$, and therefore including the M-B boundary (see Simon et al., 2016; 2017 for analytical procedures). The ${ }^{10} \mathrm{Be}$ concentrations were normalized using ${ }^{9} \mathrm{Be}$ in order to minimize the effects of environmental disturbances and provide the most accu- rate geomagnetic interpretations (Bourlès et al., 1989). The obtained authigenic ${ }^{10} \mathrm{Be} /{ }^{9} \mathrm{Be}$ ratio record serves as a proxy for the geomagnetic field intensity, and is remarkably consistent with the high-resolution relative paleointensity (RPI) signal (Fig. 4; Simon et al., 2019). This high correlation between two independent proxies, the ${ }^{10} \mathrm{Be} /{ }^{9} \mathrm{Be}$ signal being unaffected by lock-in depth, demonstrates that the magnetization acquisition conserved the timing of rapid geomagnetic features in the Chiba composite section, thereby enabling accurate and reliable paleomagnetic interpretations. The record shows significant increases in ${ }^{10} \mathrm{Be}$ production near the paleointensity low interval corresponding to the M-B boundary, and a clear diminution coherent with the geomagnetic field recovery at the first stage of the Brunhes Chron (Channell et al., 2009). Calibrating the authigenic ${ }^{10} \mathrm{Be} /{ }^{\rho} \mathrm{Be}$ ratio in terms of the Virtual Axial Dipole Moment (VADM) using a theoretical approach (Simon et al., 2018b) shows that the polarity switch phase of the M-B geomagnetic reversal occurs at low dipole field intensity, $2.3 \pm 0.3 \times$ $10^{22} \mathrm{Am}^{2}$, consistent with values measured by transitional lava flows (e.g., Valet and Fournier, 2016; Singer et al., 2019). These high-resolution paleomagnetic and authigenic ${ }^{10} \mathrm{Be} /{ }^{9} \mathrm{Be}$ ratio data furnish the Chiba composite section with one of the most detailed records of the geomagnetic field reversal through the M-B boundary.

\section{Radiometric Age of the Byk-E Tephra}

A high precision (SHRIMP-II - sensitive high-resolution ion microprobe) U-Pb zircon age for the Byk-E tephra was reported by Suganuma et al. (2015). In total, 63 zircon grains were analysed from the Yanagawa section, and 24 grains formed the youngest age population. This population gave a weighted mean of $772.7 \pm 7.2 \mathrm{ka}$ (mean square of weighted deviates, MSWD, $=0.81$ ) for the eruption/depositional age of the Byk-E tephra (Fig. 18b-d; Suganuma et al., 2015). Because U$\mathrm{Pb}$ dating is relatively free from assumptions regarding standardization and decay constants, the U-Pb zircon age of the Byk-E tephra is an important radioisotope age constraint for the M-B boundary in the Chiba composite section and elsewhere.

\section{Correlation with Other Geological Archives}

\section{Japanese archipelago}

The pollen-based paleoclimate record (broadleaved/AP ratio and MAT) from the Chiba composite section correlates well with other pollen records in Japan (GS-SB-1, CHOSHI-1, and Osaka Bay core; localities of the cores shown in Fig. 1c and 2) that span the LowerMiddle Pleistocene boundary (Fig. 19). Correlation is initially based on the published age model for each record, and secondarily tuned by the paleomagnetic timescale, $\delta^{18} \mathrm{O}$ records, marker tephra beds, $\mathrm{U}-\mathrm{Pb}$ zircon age, etc., as available. Results of the timing of the termination, warming, and thermal maximum are generally in-phase between records from the Kanto Basin. Although a slight delay in the thermal maximum is apparent in the Osaka Bay MAT results, broadleaved/AP curves show relatively good agreement between those obtained from Osaka Bay and the Chiba composite section, as well as with the global $\delta^{18} \mathrm{O}$ stratigraphy. Marine and terrestrial paleoclimatic signals docu- 


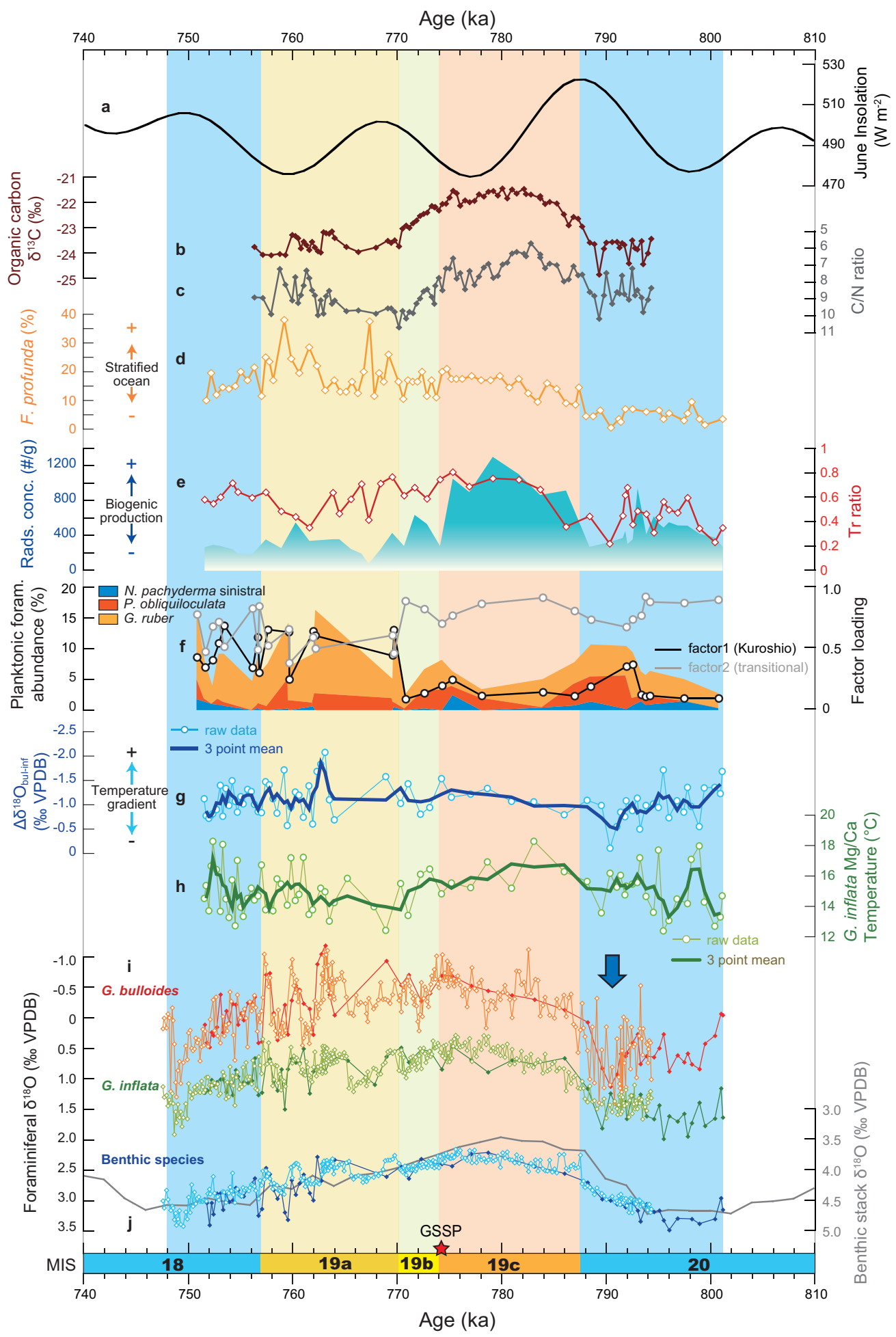

Figure 17. Paleoclimatic and paleoceanographic records from MIS 20 to MIS 18 for the Chiba composite section (modified and corrected from Suganuma et al., 2018). (a) $65^{\circ} \mathrm{N}$ insolation in June (Laskar et al., 2004). (b) Organic carbon stable isotope ( $\left.{ }^{13} C_{o r g}\right)$ and (c) C/N ratio (=Total organic carbon: TOC/total nitrogen: TN) for bulk samples. (d) Relative abundance of F. profunda (Kameo et al., 2020). (e) Blue shaded area: Radiolarian concentrations (proxy for biological production); red line: Tr values (sea-surface temperature index based on warm-and coldwater radiolarian species). (f) Relative abundance of planktonic foraminifera and results of factor analysis (Suganuma et al., 2018; Shikoku

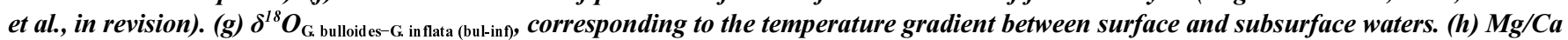
paleotemperature for $\mathrm{G}$. inflata $\left(\mathrm{T}_{\mathrm{inf}}\right)$ (Kubota et al., 2020). (i) oxygen isotope ( $\delta^{18} \mathrm{O}$ ) records of the planktonic (G. bulloides and $\mathrm{G}$. inflata) and benthic foraminifera from the Chiba composite section (Suganuma et al., 2015; Okada et al., 2017; Suganuma et al., 2018; Haneda et al., 2020b). The red/dark-green/dark-blue lines with solid diamonds are from the Yanagawa, Urajiro, and Kokusabata sections (1.0 $\mathrm{m}$ spacing), and orange/light-green/light-blue lines with open diamonds are from the Yoro River and Yoro-Tabuchi sections (0.1 to 0.5 m spacing) (see Fig. 9). (j) LR04 benthic stack (Lisiecki and Raymo, 2005). The blue arrow marks the suggested position of the Younger Dryas-type cooling event. 
mented in the Chiba composite section therefore permit detailed correlation with other sites in Japan, and will facilitate future testing of a hypothesized linkage between the geomagnetic field intensity and the global/regional climate (e.g., Kitaba et al., 2013; Hyodo and Kitaba, 2015; Kitaba et al., 2017; Ueno et al., 2019).

\section{Central and Northern Asia}

The paleoclimatic record from the Chiba composite section correlates well with those of East Siberia (Lake Baikal and Lake El'gygytgyn) and the Chinese Loess Plateau, all of which show similar warm climates during MIS 19c to those reflected in the pollen records obtained from the Pacific margin of east central Japan (Fig. 16).

In addition, a small fluctuation is also recognised during Termination IX in the Lake Baikal record as well as the Chiba composite section, which is reminiscent of the Younger Dryas-type cooling event just prior to Termination I. The general agreement among paleoclimate records from the Chiba composite section, Lake Baikal, Lake El'gygytgyn, and the Chinese loess-paleosol sequences illustrates the potential for fine-scale interhemispheric correlation of the Early-Middle Pleistocene boundary interval using climatostratigraphic signals.

\section{Europe}

Correlation between the Chiba composite section and the Montalbano Jonico section (MJS) in Italy (Bertini et al., 2015; Marino et al., 2015; Toti, 2015; Maiorano et al., 2016; Simon et al., 2017; Nomade et al., 2019) is summarized in Figure 20. Although it is not possible to identify the M-B boundary in the MJS due to late diagenetic processes resulting in complete remagnetization (Sagnotti et al., 2010), the posi- tion and hence the age of the $\mathrm{M}-\mathrm{B}$ geomagnetic reversal was estimated by the authigenic ${ }^{10} \mathrm{Be} /{ }^{9} \mathrm{Be}$ record (Simon et al., 2017; Nomade et al., 2019). Therefore, the age correlation for these two records is constrained by the directional (paleomagnetic) M-B boundary at the Chiba composite section and ${ }^{10} \mathrm{Be}$ flux anomaly at the MJS, the latter corresponding approximately to the paleomagnetic boundary in the Chiba composite section (Okada et al., 2017; Simon et al., 2017; 2019; Haneda et al., 2020a).

The two paleoclimatic records are generally consistent with each other. Regarding the MJS profile, the Pollen Temperature Index (PTI) and Arboreal Pollen percentage (AP\%) records show successive changes in temperature and precipitation by the alternation between deciduous forest and semi-arid steppe to wooded steppe vegetation (Bertini et al., 2015; Marino et al., 2015; Fig. 20). Although, the onset of warm and humid conditions is relatively concurrent with the peak of MIS $19 \mathrm{c}$ (19.3 in Marino et al., 2015), the initiation of full interglacial conditions is slightly delayed relative to that of the benthic $\delta^{18} \mathrm{O}$ records (base of the "MIS 19 plateau") at the MJS (thin dotted line in Fig. 20). In addition, Marino et al. (2015) reported that the lowering of PTI and $\mathrm{AP} \%$ values at $771.8 \mathrm{ka}$ (thick dashed line) and subsequent increase is thought to correspond to MIS $19 \mathrm{~b}$ and MIS 19a, respectively.

The Mediterranean climate pattern shown by the PTI and AP\% data from the MJS is nonetheless generally consistent with the MAT and broadleaved pollen data from the Chiba composite section from late MIS 20 to early MIS 18 (Fig. 20). The initiation of full interglacial conditions in the Chiba composite section generally coincides with the benthic $\delta^{18} \mathrm{O}$ records (based on the "MIS 19 plateau"). The termination of full interglacial conditions in the Chiba composite section is at ca. 775 ka based on the pollen record, an event close in age both to a major oceanic shift reflected in the dinoflagellate cyst record at $772.8 \mathrm{ka}$,

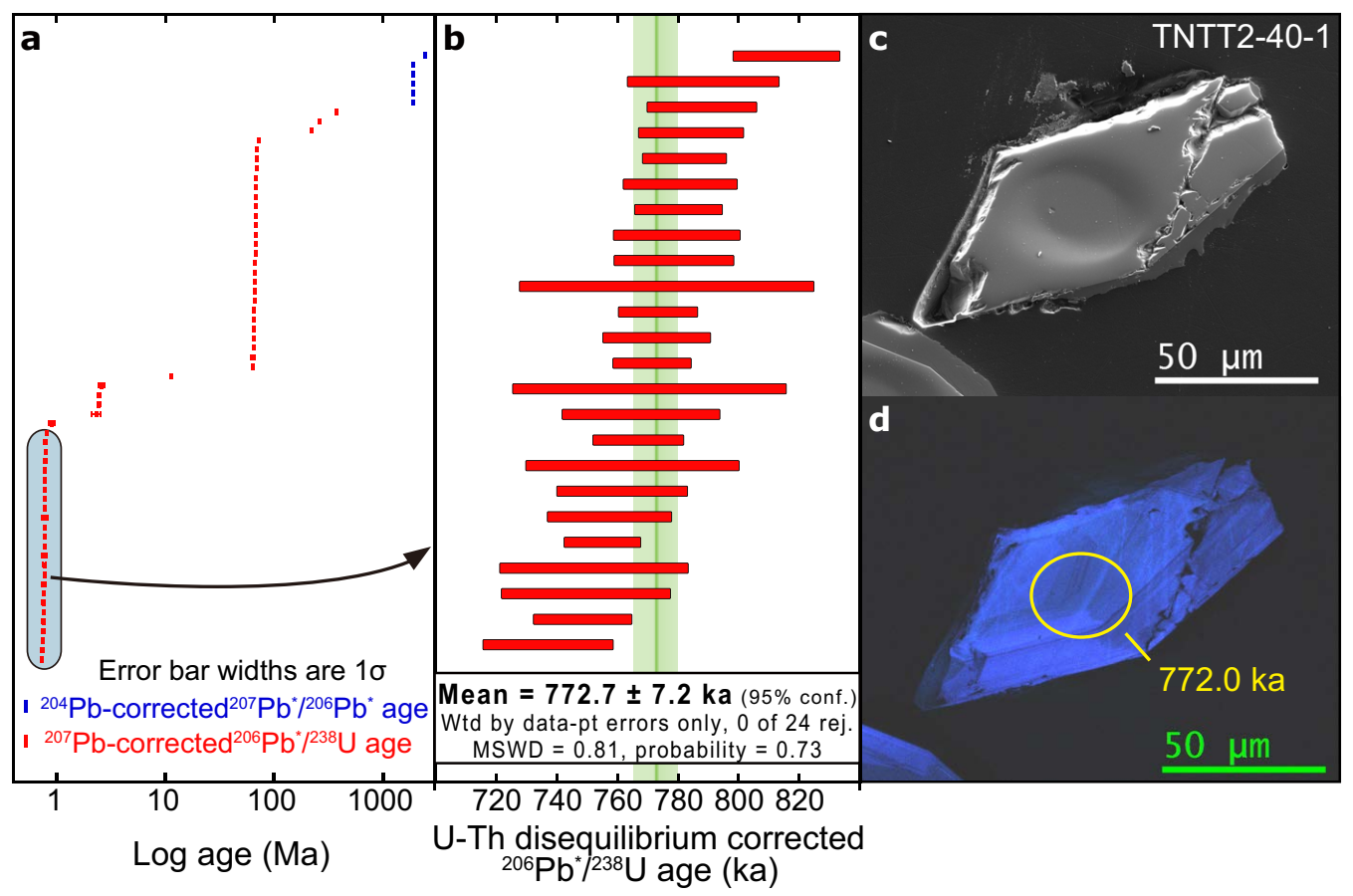

Figure 18. U-Pb ages and scanning electron microscope image of zircons (modified from Suganuma et al., 2015). U-Pb dates for all analysed zircons (a) and for the Byk-E tephra (b). Secondary electron image (c) and cathodoluminescence image (d) for a zircon from the Byk-E tephra. SIMS pits and location of the analysis for the U-Pb date are shown in (d). Abbreviation: MSWD, mean square of weighted deviates. 


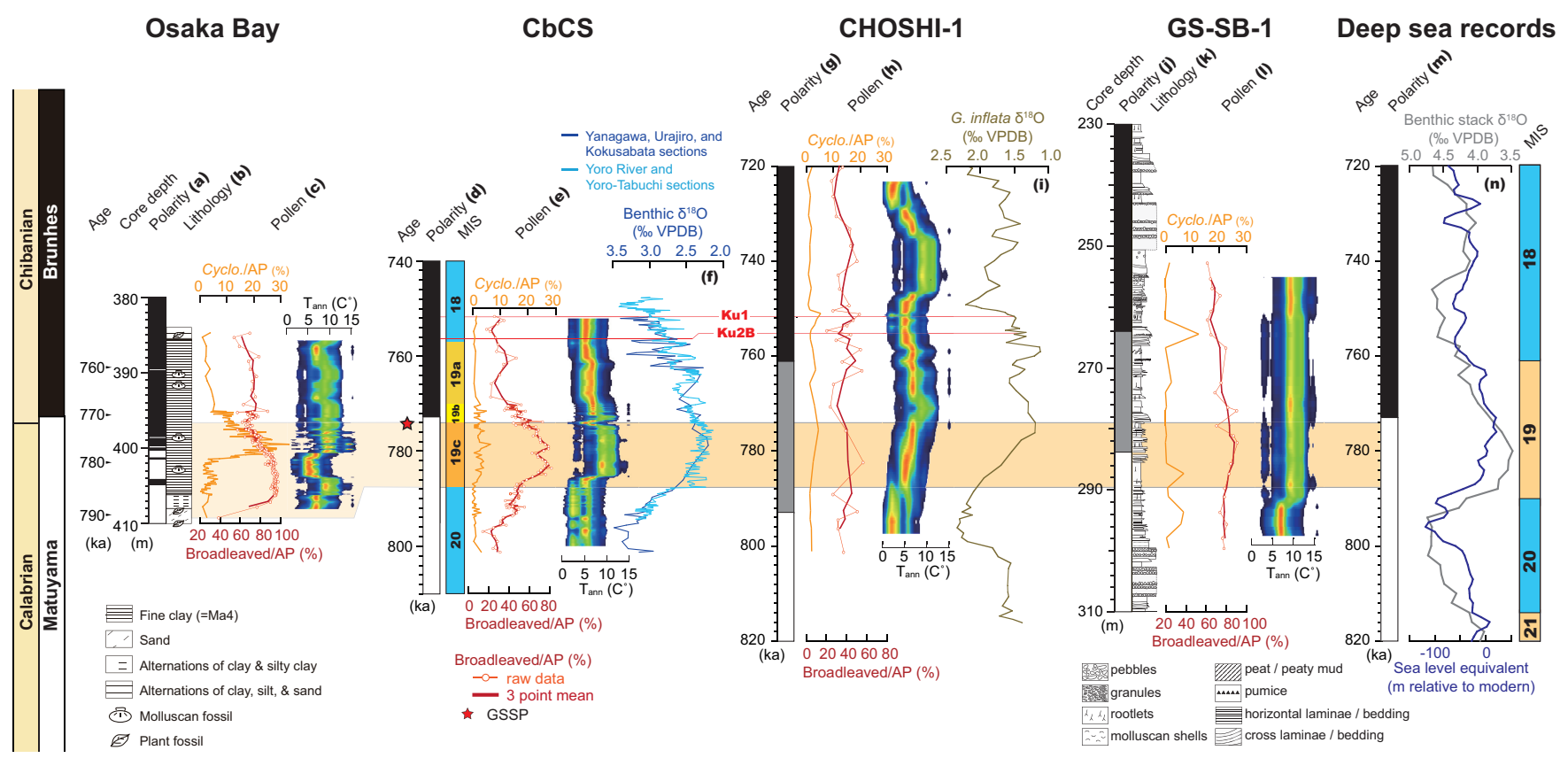

Figure 19. Comparison of pollen records and oxygen isotope $\left(\delta^{18}\right.$ ) stratigraphy from late MIS 20 to early MIS 18 between Osaka Bay and three palynological sites in the Kanto District of Japan (Chiba composite section (CbCS), CHOSHI-1, and GS-SB-1). The warm climate proxy uses the proportion of Cyclobalanopsis (evergreen oak), and the ratio of broadleaved trees to the total arboreal pollen excluding Pinus (Cyclo. AP and broadleaved/AP, respectively). Quantified variations of mean annual temperature $\left(T_{a n n}\right)$ based on the modern analog technique (MAT) of Nakagawa et al. (2002) are redrawn with the same format; Pinus is excluded from the palynoflora, and the latest version of the computing software (Polygon 2.4.4) is used. (a) and (b) Magnetostratigraphy and lithology of the Osaka Bay core (Hyodo et al., 2006). The fine clay interval of the Osaka Bay core corresponds to the Ma4 marine clay, which represents a transgressive phase including the Matuyama-Brunhes (MB) boundary and is assigned to MIS 19 (Hyodo et al., 2006). (c) Pollen and paleotemperature record from the Osaka Bay core (Kitaba et al., 2009, 2012, 2013). (d) Magnetostratigraphy of the CbCS is based on Okada et al. (2017). (e) Pollen record from the Chiba composite section (Suganuma et al., 2018). (f) benthic foraminiferal oxygen isotope $\left(\delta^{18} O\right)$ stratigraphy (Suganuma et al., 2015; Okada et al., 2017; Suganuma et al., 2018; Haneda et al., 2020b). (g) and (i) Magnetostratigraphy and $\delta^{18} \mathrm{O}$ stratigraphy of the CHOSHI-1 core are from Kameo et al. (2006). (h) Pollen record of the CHOSHI-1 core is from Okuda et al. (2006). (j)-(l) Magnetostratigraphy, lithology, and pollen record of the GS-SB-1 core are from Ueki et al. (2009), Naya et al. (2009), and Hongo et al. (2011), respectively. (m) Magnetic polarity time scale (Ogg et al., 2016). (n) LR04 benthic stack (Lisiecki and Raymo, 2005) and sea level proxy (Elderfield et al., 2012). The age model of the Osaka Bay core is based on the periodic deposition of transgressive and regressive units, estimated using fluctuations of marine vs freshwater and brackish diatom assemblages within a complex sedimentary setting (Hyodo et al., 2006). The small discrepancy between the Osaka Bay and other records including the M-B boundary horizon may originate with the age model of the Osaka Bay core. Gray shading on the magnetostratigraphy of the GS-SB-1 and CHOSHI-1 cores represents transitional zones (intermediate directions) during the geomagnetic reversal. Modified and corrected from Suganuma et al. (2018).

and the MIS $19 \mathrm{c} / \mathrm{b}$ boundary at $773.9 \mathrm{ka}$. These climatic events are significant for correlation because their ages are close to that of the the Byk-E tephra bed, and hence the GSSP, at $774.1 \mathrm{ka}$. It is not known whether a brief but pronounced cooling event at $771.8 \mathrm{ka}$ recorded in the MJS (Marino et al., 2015) is related to the climatic events in the Chiba composite section, but both events are in and around the MIS 19b interval.

The recorded position of the M-B boundary relative to associated paleoclimatic and paleoceanographic signals is generally consistent on a global scale and dated at around 776-771 ka with the exception of two notable Italian localities, the Sulmona basin (Giaccio et al., 2015) and Valle di Manche (Capraro et al., 2017), for which the ages are older by about 5 to $10 \mathrm{ka}$. Recent analyses on new samples suggest that sediments from the Sulmona sequence do not carry a reliable high-resolution record of the geomagnetic field, therefore questioning the precise stratigraphic inference of the M-B boundary (Evans and Muxworthy, 2018). In the Valle di Manche record from the Crotone basin, Southern Italy, an incomplete peak of authigenic ${ }^{10} \mathrm{Be} /{ }^{9} \mathrm{Be}$ ratio is recognized ca. $2.8 \mathrm{~m}$ above (from table 1 and fig. 7 in Capraro et al., 2019) the identified M-B boundary (Macrì et al., 2018). While Capraro et al. (2019) suggested that this ${ }^{10} \mathrm{Be}$ half-peak entirely originates from non-geomagnetic local inputs, its age of ca. $775 \mathrm{ka}$ is fully coherent with the global ${ }^{10} \mathrm{Be}$ overproduction event associated with the M-B geomagnetic reversal (Raisbeck et al., 2006; Suganuma et al., 2010; Simon et al., 2017; 2018; Valet et al., 2019), making a geomagnetic origin seem more likely (Head, 2019). These results therefore potentially reconcile differences in the recorded $\mathrm{M}-\mathrm{B}$ ages.

A Younger Dryas-type cooling event interrupts Termination IX at the MJS and Sulmona lake records. Multi-millennial to millennial scale variations in the later part of MIS 19 as recorded at MJS are also recognised in the Chiba composite records. These rapid climatic changes are most likely explained by disruption/reactivation of the Meridional Overturning Circulation (MOC), as suggested by Tzedakis et al. (2012). 


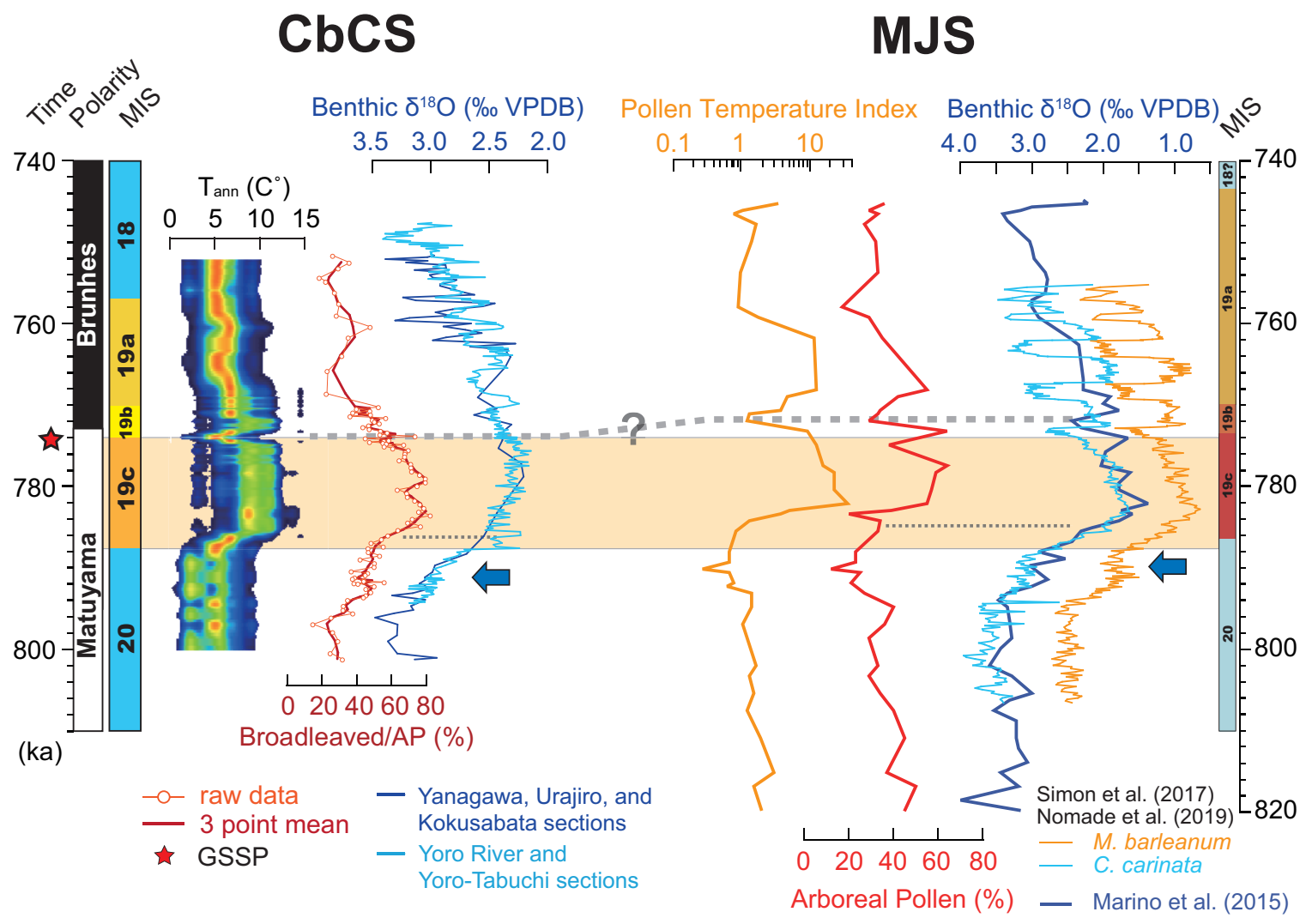

Figure 20. Comparison of pollen-based indices and oxygen isotope $\left(\delta^{18} \mathrm{O}\right)$ stratigraphy from late MIS 20 to early MIS 18 between the Chiba composite section (CbCS) (Suganuma et al., 2015; Okada et al., 2017; Suganuma et al., 2018; Haneda et al., 2020b) and the Montalbano Jonico section (MJS), southern Italy (Bertini et al., 2015; Marino et al., 2015; Simon et al., 2017; Nomade et al., 2019). Thin dotted lines indicate timings of the base of "MIS 19 plateau" in the CbCS and MJS on the $\delta^{18}$ O stratigraphy, whereas a thick dashed line denotes the lowering of temperature indices around the MIS 19c-b boundary. Horizons of the Younger Dryas-type cooling events in the CbCS and MJS are shown by blue arrows. Modified and corrected from Suganuma et al. (2018).

\section{Ice core and ocean records}

The deuterium excess record of the EPICA Dome C Antarctic ice core (Jouzel et al., 2007), $\delta^{18} \mathrm{O}$ records from the North Atlantic (IODP U1308; Hodell et al., 2008) and Indian Ocean (MD90-0961; Valet et al., 2014), and the LR04 benthic stack (Lisiecki and Raymo, 2005), are all consistent with the astronomical configuration from MIS 20 to MIS 18 as reflected also in the Chiba composite section (Fig. 21). The position of the $\mathrm{M}-\mathrm{B}$ boundary relative to these paleoclimatic and paleoceanographic records is also generally consistent.

The Younger Dryas-type cooling event is recorded in the North Atlantic, Indian Ocean, and the synthetic Greenland climatic record. The multi-millennial to millennial scale variations in the later part of the MIS 19 are also recognised in these records. The generally consistent changes in paleoclimatic and paleoceanographic records, in terms of amplitude and timing, even at the multi-millennial to millennial scale during Termination IX and the later part of MIS 19, support teleconnections not only between the Pacific and Atlantic, but also with the Indian Ocean (Fig. 21; Suganuma et al., 2018). The smaller amplitude of the multi-millennial to millennial scale variations in the Pacific and Indian oceans are consistent with this interpretation.

\section{Chibanian Stage/Age}

Regional stages have been used in Japan from the Miocene to Lower Pleistocene along the Sea of Japan (The Japanese Association for Petroleum Technology, 2013) but no regional stages exist for the Middle Pleistocene or above. The Chibanian is therefore a new stage/age without precedence in Japan, its base coincident with that of the Middle Pleistocene Subseries/Subepoch. The term Chibanian derives from the name of the Chiba prefecture in which the GSSP is located.

\section{Requirements Fulfilled by the GSSP}

The Chiba section meets all requirements for a GSSP as recommended by Remane et al. (1996), especially given that "the stratotype section should contain the best possible record of the relevant marker event" (Remane et al., 1996, p. 79), in this case the M-B geomagnetic reversal.

The Chiba section, a major component of the Chiba composite section, is extensively exposed over $17.7 \mathrm{~m}$ in stratigraphic thickness, comprising hemipelagic silty sediments. This section is part of a larger Quaternary succession within the Boso Peninsula that covers the past 2 million years without a substantial hiatus. No hiatuses are detected in 


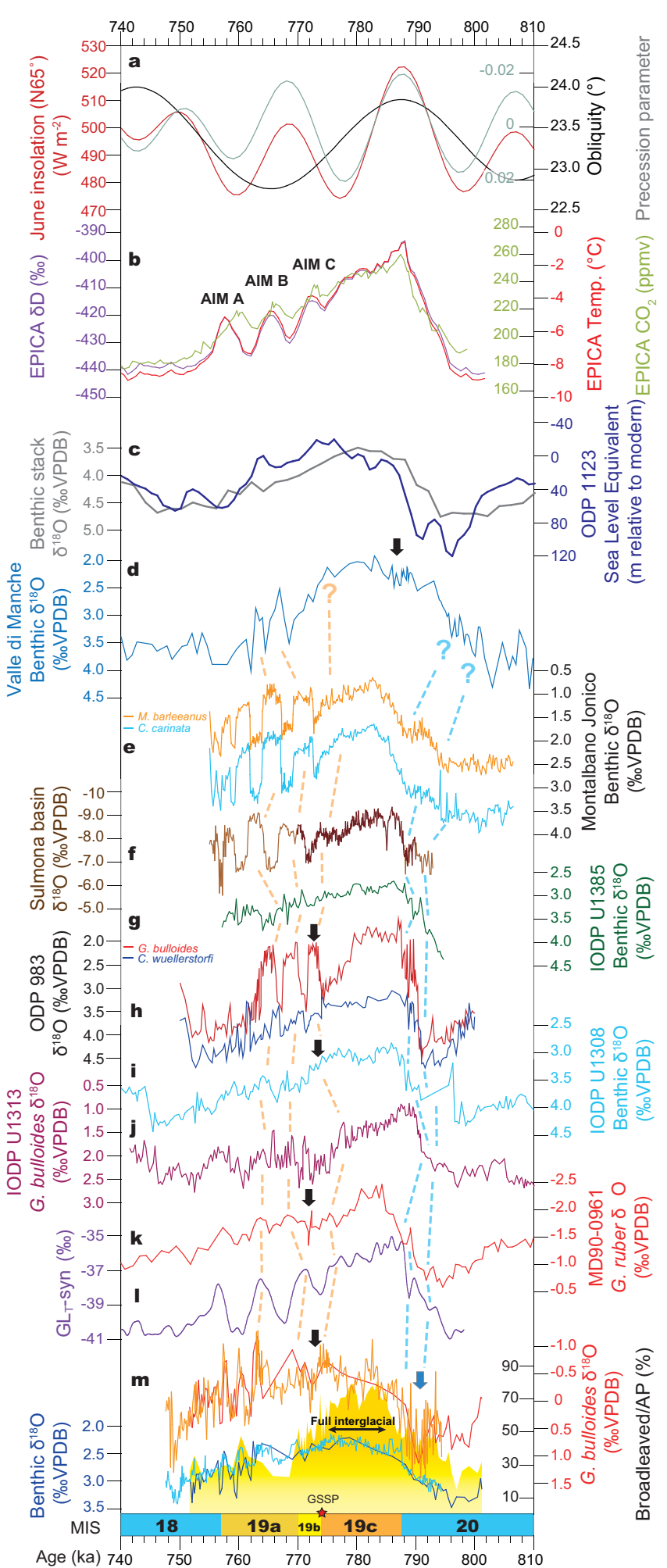

Figure 21. Paleoclimatic and paleoceanographic changes through MIS 19. (a) $65^{\circ} \mathrm{N}$ insolation in June, precession parameter, and obliquity (Laskar et al., 2004). (b) Deuterium isotope (Augustin et al., 2004), temperature change (DTs) (Jouzel et al., 2007) from deuterium content, and $\mathrm{CO}_{2}$ concentration (Bereiter et al., 2015) records of the European Project for Ice Coring in Antarctica (EPICA) Dome C ice core. (c) LR04 benthic stack (Lisiecki and Raymo, 2005) and sea level proxy (Elderfield et al., 2012). (d) Benthic oxygen isotope $\left(\delta^{18} O\right)$ record from the Valle di Manche section, Italy (Capraro et al., 2017), (e) Benthic $\delta^{18} \mathrm{O}$ record from the Montalbano Jonico section, Italy (Simon et al., 2017; Nomade et al., 2019). (f) $\delta^{18}$ O records from the Sulmona paleolake sediments, central ltaly (Giaccio et al., 2015; Regattieri et al., 2019). (g)-(j) $\delta^{18} \mathrm{O}$ records from Integrated Ocean Drilling Program (IODP) Site U1385 (Sánchez Goñi et al., 2016), Ocean Drilling Program (ODP) Site 983 (Channell and Kleiven, 2000), IODP Site U1308 (Hodell et al., 2008), and IODP Site U1313 (Ferretti et al., 2015) from the North Atlantic. (k) $\delta^{18} \mathrm{O}$ records from the Indian Ocean core MD90-0961 site (Valet et al., 2014). (I) A synthetic record of Greenland climate variability $\left(\delta^{18} \mathrm{O}\right)$ based on the thermal bipolar seesaw model (Barker et al., 2011). (m) $\delta^{18} O$ stratigraphy of benthic and planktonic foraminifera as well as pollen (broadleaved/arboreal pollen, yellow shading) from the Chiba composite section (Suganuma et al., 2015; Okada et al., 2017; Suganuma et al., 2018; Haneda et al., 2020b). Red/blue lines from the Yanagawa, Urajiro, and Kokusabata sections (1.0 $\mathrm{m}$ spacing), and orange and light blue lines are from the Yoro River and Yoro-Tabuchi sections (0.1 to $0.5 \mathrm{~m}$ spacing). A thin black arrow indicates length of full interglacial conditions inferred from the pollen record (CbCS-2a). Thick black arrows are the horizons of the Matuyama-Brunhes boundary of each record. Location of the Younger Dryas-type cooling event is shown by a blue arrow. Modified (with correction) from fig. 16i of Suganuma et al. (2018).

the Chiba composite section, and high sedimentation rates are recorded, for a deep marine, hemipelagic depositional setting, with averaged values of $157 \mathrm{~cm} / \mathrm{kyr}$, a rate of $89 \mathrm{~cm} / \mathrm{kyr}$ across the GSSP interval, and a minimum rate of $44 \mathrm{~cm} / \mathrm{kyr}$ for the highest sea level interval.

The depositional setting of the Chiba composite section is stable and generally devoid of wave/current influences, which are common in shelf environments. The section comprises silty sediments without slumps or faults throughout the succession. No significant diagenetic alteration has affected the Chiba composite section.

The Chiba composite section conserves a diverse and well-preserved record of fossils of pollen and marine microfossils and macrofossils including planktonic and benthic foraminifera, calcareous nannofossils, diatoms, radiolarians, planktonic gastropods, molluscs, ostracodes, and dinoflagellate cysts.

No distinctive vertical facies changes are observed within the interval of the GSSP, as this interval is characterized by a uniform silty unit with parallel bedding planes, and minor sandy beds occurring only in the lower part of the section. Although the Byk-E tephra bed represents a distinctive lithological change, detailed analysis shows it to have settled passively through the water column without remobilization or erosion.

The high deposition rates combined with hemipelagic sedimentation on a continental slope facing the Pacific Ocean created favorable conditions for long-range correlations using biostratigraphy, chemostratigraphy, and magnetostratigraphy. Because of its location, the Chiba composite section records terrestrial and marine paleoclimatic signatures relating to the westerly jet, East Asian monsoon, and North Pacific Gyre (subtropical and subpolar).

With respect to radiometric dating, a U-Pb zircon date of $772.7 \pm 7.2 \mathrm{ka}$ has been obtained from the Byk-E tephra bed at the precise horizon of the GSSP. This and other tephra beds intercalated in the Chiba composite section are potential targets for future ${ }^{40} \mathrm{Ar}^{139} \mathrm{Ar}$ and/or ID TIMS $\mathrm{U}-\mathrm{Pb}$ geochronology.

The Chiba composite section represents one of the most detailed paleomagnetic records yet obtained for the M-B geomagnetic reversal from marine sediments. These records include both directional and 
relative intensity data at very high temporal resolution (as little as 40 years between samples) and will be key to understanding the dynamics of the geomagnetic dynamo and for calibrating the geological time scale. A cosmogenic nuclide record (authigenic ${ }^{10} \mathrm{Be} /{ }^{9} \mathrm{Be}$ ratio) complements the paleomagnetic records by providing an independent reconstruction of paleointensity changes.

Chemostratigraphy throughout the Chiba composite section is provided by the analyses of foraminiferal $\delta^{18} \mathrm{O}$, organic and inorganic carbon isotopes, a $\mathrm{Mg} / \mathrm{Ca}$ paleotemperature proxy, and bulk chemistry of major elements by x-ray fluorescence (XRF).

With respect to paleogeographical context and facies relationships, the Chiba composite section occurs within the Kazusa forearc basin, where it represents a continental slope setting. The main part of the Chiba composite section is dominated by silty beds and is assigned to transgressive and highstand systems tracts of a fifth-order depositional sequence as defined by Mitchum and VanWagoner (1991).

The GSSP will be indicated by a permanently fixed marker. The Chiba composite section is $50-70 \mathrm{~km}$ from Narita and Haneda (Tokyo) international airports, and within three hours of these airports by car or public transport plus a 10 and 40 minute walk, respectively. The Chiba section is located almost entirely on public land, and for privately owned land an Ichihara City ordinance allows sampling by bona fide researchers regardless of nationality. This ensures access to both the Chiba and superjacent Yoro-Tabuchi sections. Guarantees are in place for the area around both sections to be permanently protected and managed by Ichihara City, the Chiba Prefectural Board of Education, and the Agency for Cultural Affairs, as a natural monument with no planning permitted for any urban development.

\section{Conclusions}

The Chiba composite section (MIS 20 to early MIS 18; 801.1-747.8 ka) is a well-exposed, continuous and expanded marine silty sedimentary succession containing well-preserved pollen, marine micro- and macrofossils, a detailed paleomagnetic record, and numerous tephra beds. Ultra-high resolution oxygen $\left(\delta^{18} \mathrm{O}\right)$ stratigraphy, supported by a $\mathrm{U}-\mathrm{Pb}$ zircon age for the Byk-E tephra bed (772.7 $\pm 7.2 \mathrm{ka}$ ) close to the M-B boundary, provide robust and precise chronological constraints. Pollen, marine microfossil data and planktonic foraminiferal $\delta^{18} \mathrm{O}$ and $\mathrm{Mg} / \mathrm{Ca}$ paleotemperature records reveal the complex influence of glacial-interglacial climatic variations. A Younger Dryas-type cooling event is recognised around $790 \mathrm{ka}$ during Termination IX, suggesting that such events are linked to this orbital configuration. These various attributes confirm the stratigraphic completeness of the section and constrain in time the critical interval for defining the Lower-Middle Pleistocene boundary.

The GSSP defining the base of the Chibanian Stage and Middle Pleistocene Subseries is placed at the base of the regionally widespread and significant Byk-E tephra bed in the Chiba section, with an astronomical age of $774.1 \mathrm{ka}$. The GSSP lies $1.1 \mathrm{~m}$ below the directional midpoint of the M-B boundary (772.9 ka; duration $1.7 \mathrm{kyr}$ ) which therefore serves as its primary guide. The GSSP occurs just below the top of MIS 19c at $773.9 \mathrm{ka}$ and after the termination of full interglacial conditions at $775.1 \mathrm{ka}$. It is also close to a major oceanic shift reflected in the dinoflagellate cyst record at $772.8 \mathrm{ka}$. Stratigraphic signals associ- ated with MIS 19 serve as auxiliary markers for the recognition of this GSSP, globally and in a wide range of sedimentary contexts.

\section{Acknowledgements}

We thank all members of the Chiba composite section research community*, and Gerald M. Richmond and Brad Pillans for helpful discussions on the Kazusa Group and Chiba composite section. We are also indebted to the former members of the Chiba composite section research community, especially Minoru Itihara, Yoshijiro Shinada, Nobuyuki Aida, Osamu Kazaoka, and Shun Kameyama, and to Hisao Nakagawa and Nobuaki Niitsuma, who pioneered the study of magnetostratigraphy in the Boso Peninsula. Motomaro Shirao kindly provided a beautiful photograph for the Chiba section. The ASTER Team (Didier L. Bourlès, Georges Aumaitre, and Karim Keddadouche) supported the accelerator mass spectrometry (AMS) measurements. We are also grateful for support given by the Japanese Committee of the IUGS, Society of Geomagnetism and Earth, Planetary and Space Sciences, and the Geological Society of Japan. It is a pleasure to thank all those who have co-operated with us on this project, from the Tabuchi district, Ichihara City, Chiba prefecture, Japanese Geoparks Network, Ministry of Economy, Agency for Cultural Affairs, and Ministry of Education, Culture, Sports, Science and Technology, for their kind support. Finally, we acknowledge with much gratitude the support received from colleagues on the ICS and its executive and its Subcomission on Quaternary Stratigraphy. This manuscript has been improved by helpful comments from Mike Walker, Yoshiki Saito, and the editorial process. We dedicate this paper to the memory of the late Professor Hisao Kumai who led the Chiba research group in its earlier stages.

*Chiba composite section community members. Participants who are not authors of this paper are listed alphabetically: Eseroghene J. Balota, Misato Hongo, Kenji Horie, Masayuki Hyodo, Atsuo Igarashi, Osamu Ishizuka, Moto Kawamata, Kenji Kawamura, Takahiro Kojima, Jun-Ichi Kimura, Itaru Ogitsu, Jun'ichi Okuno, Ryoko Senda, Kizuku Shikoku, Testuo Sueyoshi, Manami Sugaya, Mami Takehara, Masami Watanabe, Hisashi Yabusaki, Takeshi Yoshida

\section{References}

Aida, N., 1997, Paleomagnetic stratigraphy of the type section (proposed site) for the Lower/Middle Pleistocene boundary Kokumoto Formation. In: Kawamura, M., Oka, T., and Kondo, T. (Eds.), Commemorative volume for Professor Makoto Kato. pp. 275-282 (in Japanese with English abstract).

Anand, P., Elderfield, H., and Conte, M.H., 2003, Calibration of $\mathrm{Mg} / \mathrm{Ca}$ thermometry in planktonic foraminifera from a sediment trap time series. Paleoceanography, v. 18, doi:10.1029/2002PA000846

Anonymous, 1988, Biostratigraphy rejected for Pleistocene subdivisions. Episodes, v. 11, pp. 228.

Anthonissen, D.E., and Ogg, J.G., 2012, Cenozoic and Cretaceous biochronology of planktonic foraminifera and calcareous nannofossils. In: Gradstein, F.M., Ogg, J.G., Schmitz, M., and Ogg, G., (Eds.), The Geologic Time Scale 2012. Elsevier, Boston, pp. 1083-1127.

Aoki, N., 1968, Benthonic foraminifera of Kazusa Group, Boso Peninsula. Transactions and Proceedings of the Paleontological Society of Japan, v. 70, pp. 238-266. 
Augustin, L., Barbante, C., Barnes, P.R.F., Barnola, J.M., Bigler, M., Castellano, E., Cattani, O., Chappellaz, J., DahlJensen, D., Delmonte, B., Dreyfus, G., Durand, G., Falourd, S., Fischer, H., Fluckiger, J., Hansson, M.E., Huybrechts, P., Jugie, R., Johnsen, S.J., Jouzel, J., Kaufmann, P., Kipfstuhl, J., Lambert, F., Lipenkov, V.Y., Littot, G.V.C., Longinelli, A., Lorrain, R., Maggi, V., Masson-Delmotte, V., Miller, H., Mulvaney, R., Oerlemans, J., Oerter, H., Orombelli, G., Parrenin, F., Peel, D.A., Petit, J.R., Raynaud, D., Ritz, C., Ruth, U., Schwander, J., Siegenthaler, U., Souchez, R., Stauffer, B., Steffensen, J.P., Stenni, B., Stocker, T.F., Tabacco, I.E., Udisti, R., van de Wal, R.S.W., van den Broeke, M., Weiss, J., Wilhelms, F., Winther, J.G., Wolff, E.W., and Zucchelli, M., 2004, Eight glacial cycles from an Antarctic ice core. Nature, v. 429, pp. 623-628.

Baba, K., 1990, Molluscan fossil assemblages of the Kazusa Group, South Kwanto, central Japan. Keio Yochisha, Tokyo, 364 p. (in Japanese with English abstract).

Balota, E.J., Head, M.J., Okada, M., Suganuma, Y., and Haneda, Y., Paleoceanography and dinoflagellate cyst stratigraphy across the LowerMiddle Pleistocene Subseries (Calabrian-Chibanian Stage) boundary at the Chiba composite section, Japan. Progress in Earth and Planetary Science (in press).

Barker, S., Knorr, G., Edwards, R.L., Parrenin, F., Putnam, A.E., Skinner, L.C., Wolff, E., and Ziegler, M., 2011, 800,000 years of abrupt climate variability. Science, v. 334, pp. 347-351.

Bazin, L., Landais, A., Lemieux-Dudon, B., Kele, M.H.T., Veres, D., Parrenin, F., Martinerie, P., Ritz, C., Capron, E., Lipenkov, V., Loutre, M.F., Raynaud, D., Vinther, B., Svensson, A., Rasmussen, S.O., Severi, M., Blunier, T., Leuenberger, M., Fischer, H., Masson-Delmotte, V., Chappellaz, J., and Wolff, E., 2013, An optimized multi-proxy, multi-site Antarctic ice and gas orbital chronology (AICC2012): 120-800 ka. Climate of the Past, v. 9, pp. 1715-1731.

Bereiter, B., Eggleston, S., Schmitt, J., Nehrbass-Ahles, C., Stocker, T.F., Fischer, H., Kipfstuhl, S., and Chappellaz, J., 2015, Revision of the EPICA Dome $\mathrm{C} \mathrm{CO}^{2}$ record from 800 to $600 \mathrm{kyr}$ before present. Geophysical Research Letters, v. 42, pp. 542-549.

Berger, W.H., Yasuda, M.K., Bickert, T., Wefer, G., and Takayama, T., 1994, Quaternary time scale for the Ontong Java Plateau: Milankovitch template for Ocean Drilling Program Site 806. Geology, v. 22, pp. 463-467.

Bertini, A., Toti, F., Marino, M., and Ciaranfi, N., 2015, Vegetation and climate across the Early-Middle Pleistocene transition at Montalbano Jonico, southern Italy. Quaternary International, v. 383, pp. 74-88.

Bourlès, D.L., Raisbeck, G.M., and Yiou, F., $1989,{ }^{10} \mathrm{Be}$ and ${ }^{9} \mathrm{Be}$ in marine sediments and their potential for dating. Geochimica et Cosmochimica Acta, v. 53, pp. 443-452.

Brown, E., Colling, A., Park, D., Phillips, J., Rothery, D., and Wright, J., 2001, Chapter 3 - Ocean currents. In: Brown, E., Colling, A., Park, D., Phillips, J., Rothery, D., and Wright, J. (Eds.), Ocean Circulation (Second Edition). Butterworth-Heinemann, Oxford, pp. 37-78.

Butzer, K.W., and Isaac, G.L., 1975, After the Australopithecines. De Gruyter Mouton, Hague, 911 p.

Capraro, L., Tateo, F., Ferretti, P., Fornaciari, E., Macrì, P., Scarponi, D., Preto, N., Xian, F., Kong, X., and Xie, X., 2019, A Mediterranean perspective on ${ }^{10} \mathrm{Be}$, sedimentation and climate around the Matuyama/Brunhes boundary: les liaisons dangereuses? Quaternary Science Reviews, v. 226, 106039. doi:10.1016/j.quascirev.2019.106039

Capraro, L., Ferretti, P., Macrì, P., Scarponi, D., Tateo, F., Fornaciari, E., Bellini, G., and Dalan, G., 2017, The Valle di Manche section (Calabria, Southern Italy): A high resolution record of the Early-Middle Pleistocene transition (MIS 21-MIS 19) in the Central Mediterranean. Quaternary Science Reviews, v. 165, pp. 31-48.

Channell, J.E.T., and Kleiven, H.F., 2000, Geomagnetic palaeointensities and astrochronological ages for the Matuyama-Brunhes boundary and the boundaries of the Jaramillo Subchron: palaeomagnetic and oxygen isotope records from ODP Site 983. Philosophical Transactions of the Royal Society B Biological Sciences, v. 358, pp. 1027-1047.
Channell, J.E.T., Xuan, C., and Hodell, D.A., 2009, Stacking paleointensity and oxygen isotope data for the last $1.5 \mathrm{Myr}$ (PISO-1500). Earth and Planetary Science Letters, v. 283, pp. 14-23.

Channell, J.E.T., Hodell, D.A., Singer, B.S., and Xuan, C., 2010, Reconciling astrochronological and ${ }^{40} \mathrm{Ar} /{ }^{\beta 9} \mathrm{Ar}$ ages for the Matuyama-Brunhes boundary and late Matuyama Chron. Geochemistry, Geophysics, Geosystems, v. 11, Q0AA12. doi:10.1029/2010GC003203

Channell, J.E.T., 2017, Complexity in Matuyama-Brunhes polarity transitions from North Atlantic IODP/ODP deep-sea sites. Earth and Planetary Science Letters, v. 467, pp. 43-56.

Cherepanova, M.V., Pushkar, V.S., Razjigaeva, N., Kumai, H., and Koizumi, I., 2002, Diatom biostratigraphy of the Kazusa Group, Boso Peninsula, Honshu, Japan. The Quaternary Research (Daiyonki Kenkyu), v. 41 , pp. $1-10$.

Dreyfus, G.B., Raisbeck, G.M., Parrenin, F., Jouzel, J., Guyodo, Y., Nomade, S., and Mazaud, A, 2008, An ice core perspective on the age of the Matuyama-Brunhes boundary. Earth and Planetary Science Letters, v. 274, pp. 151-156.

Elderfield, H., Ferretti, P., Greaves, M., Crowhurst, S., McCave, I.N., Hodell, D., and Piotrowski, A.M., 2012, Evolution of ocean temperature and ice volume through the mid-Pleistocene climate transition. Science, v. 337, pp. 704-709.

Evans, M.E., and Muxworthy, A.R., 2018, A re-appraisal of the proposed rapid Matuyama-Brunhes geomagnetic reversal in the Sulmona Basin, Italy. Geophysical Journal International, v. 213, pp. 1744-1750.

Ferretti, P., Crowhurst, A.J., Naafs, B.D.A., and Barbante, C., 2015, The Marine Isotope Stage 19 in the mid-latitude Northern Atlantic Ocean: astronomical signature and intra-interglacial variability. Quaternary Science Reviews, v. 108, pp. 95-110.

Gallagher, S.J., Kitamura, A., Iryu, Y., Itaki, T., Koizumi, I., and Hoiles, P.W., 2015, The Pliocene to recent history of the Kuroshio and Tsushima Currents: a multiproxy approach. Progress in Earth and Planetary Science, v. 2, 17. doi:10.1186/s40645-015-0045-6

Giaccio, B., Regattieri, E., Zanchetta, G., Nomade, S., Renne, P.R., Sprain, C.J., Drysdale, R.N., Tzedakis, P.C., Messina, P., Scardia, G., Sposato, A., and Bassinot, F., 2015, Duration and dynamics of the best orbital analogue to the present interglacial. Geology, v. 43, pp. 603-606.

Gotanda, K., Nakagawa, T., Tarasov, P., Kitagawa, J., Inoue, Y., and Yasuda, Y., 2002, Biome classification from Japanese pollen data: application to modern-day and Late Quaternary samples. Quaternary Science Reviews, v. 21, pp. 647-657.

Guo, Z.T., Berger, A., Yin, Q.Z., and Qin, L., 2009, Strong asymmetry of hemispheric climates during MIS-13 inferred from correlating China loess and Antarctica ice records. Climate of the Past, v. 5, pp. 21-31.

Haneda, Y., Okada, M., Suganuama, Y., and Kitamura, T., 2020a, A full sequence of the Matuyama-Brunhes geomagnetic reversal in the Chiba composite section, central Japan. Progress in Earth and Planetary Science, v. 7, 44. doi:10.1186/s40645-020-00354-y

Haneda, Y., Okada, M., Kubota, Y., and Suganuama, Y., 2020b, Millennial-scale hydrographic changes in the northwestern Pacific during marine isotope stage 19: teleconnections with ice melt in the North Atlantic. Earth and Planetary Science Letters, v. 531, 115936. doi:10.1016/j.eps1.2019.115936

Head, M.J., and Gibbard, P.L., 2005, Early-Middle Pleistocene transitions: an overview and recommendation for the defining boundary. In: Head, M.J., and Gibbard, P.L. (eds.), Early-Middle Pleistocene transitions: the land-ocean evidence. Geological Society, London, Special Publication, v. 247, pp. 1-18.

Head, M.J., Pillans, B., and Farquhar, S.A., 2008, The Early-Middle Pleistocene transition: characterization and proposed guide for the defining boundary. Episodes, v. 31, pp. 255-259.

Head, M.J., and Gibbard, P.L., 2015, Early-Middle Pleistocene transitions: linking terrestrial and marine realms. Quaternary International, v. 389 , pp. 7-46.

Head, M.J., 2019, Formal subdivision of the Quaternary System/Period: 
present status and future directions. Quaternary International, v. 500, pp. 32-51.

Head, M.J., Pillans, B., Zalasiewicz, J.A., and the ICS Subcommission on Quaternary Stratigraphy, 2021, Formal ratification of subseries/subepochs for the Pleistocene Series/Epoch of the Quaternary System/ Period. Episodes (this issue).

Heusser, L.E., 1990, Northeast Asian pollen records for the last 150,000 years from deep-sea cores V28-304 and RC14-99 taken off the Pacific coast of Japan. Review of Palaeobotany and Palynology, v. 65, pp. 1-8.

Hilgen, F.J., Lourens, L.J., and Van Dam, J.A., 2012, The Neogene Period. In: Gradstein, F.M., Ogg, J.G., Schmitz, M., and Ogg, G. (Eds.), The Geologic Time Scale 2012. Elsevier, Boston, pp. 923-978.

Hodell, D.A., Channeil, J.E.T., Curtis, J.H., Romero, O.E., and Röhl, U., 2008, Onset of "Hudson Strait" Heinrich events in the eastern North Atlantic at the end of the middle Pleistocene transition ( $\sim 640 \mathrm{ka})$ Paleoceanography, v. 23. doi:10.1029/2008PA001591

Hongo, M., Naya, T., Yamaguchi, M., and Mizuno, K., 2011, Pollen assemblages of GS-SB-1 drilling core at Shobu Town, Saitama Prefecture, central Kanto plain, Japan. Bulletin of the Geological Survey of Japan, v. 62, pp. 281-318 (in Japanese with English abstract).

Hubbard, S.M., MacEachern, J.A., and Bann, K.L., 2012, Slopes. In: Knaust, D., and Bromley, R.G. (Eds.), Trace Fossils as Indicators of Sedimentary Environments. Developments in Sedimentology, v. 64, pp. 607-642.

Hyodo, M., Biswas, D.K., Noda, T., Tomioka, N., Mishima, T., Itota, C., and Sato, H., 2006, Millennial- to submillennial-scale features of the Matuyama-Brunhes geomagnetic polarity transition from Osaka Bay, southwestern Japan, Journal of Geophysical Research, v. 111, B02103. doi:10.1029/2004JB003584

Hyodo, M., and Kitaba I., 2015, Timing of the Matuyama-Brunhes geomagnetic reversal: Decoupled thermal maximum and sea-level highstand during Marine Isotope Stage 19. Quaternary International, v. 383, pp. 136-144.

Hyodo, M., Katoh, S., Kitamura, A., Takasaki, K., Matsushita, H., Kitaba, I., Tanaka, I., Nara, M., Matsuzaki, T., Dettman, D.L., and Okada, M., 2016, High resolution stratigraphy across the early-middle Pleistocene boundary from a core of the Kokumoto Formation at Tabuchi, Chiba Prefecture, Japan. Quaternary International, v. 397, pp. 16-26.

Hyodo, M., Bradák, B., Okada, M., Katoh, S., Kitaba, I., Dettman, D.L., Hayashi, H., Kumazawa, K., Hirose, K., Kazaoka, O., Shikoku, K., and Kitamura. A., 2017, Millennial-scale northern Hemisphere AtlanticPacific climate teleconnections in the earliest Middle Pleistocene. Scientific Reports, v. 7, 10036. doi:10.1038/s41598-017-10552-2

Igarashi, A., 1994, Paleoceanographic changes during the deposition of the middle Pleistocene Kazusa Group, central Japan: estimation based on the principal components analysis of planktonic foraminifera. Journal of the Geological Society of Japan, v. 100, pp. 348-359 (in Japanese with English abstract).

Igarashi, A., 1996, Biostratigraphy of the Chiba section of the Boso Peninsula toward establishing the Lower-Middle Pleistocene boundary stratotype based on planktonic foraminiferal analyses. Proceedings on the research of stratotype for the Lower-Middle Pleistocene boundary, Internal Research Group for the Lower-Middle, Middle-Upper Pleistocene Boundary, Japan Association for Quaternary Research, pp. 3645 .

Ishiwada, Y, Mitsunashi, T., Shinada,Y., and Makino, T., 1971, Geological maps of oil and gas field of Japan no.10, Mobara, 1:15,000. Geological Survey of Japan.

Itaki, T., and Ikehara, K., 2004, Middle to late Holocene changes of the Okhotsk Sea intermediate water and their relation to atmospheric circulation. Geophysical Research Letters, v. 31, L24309. doi:10.1029/ 2004GL021384

Ito, M., 1992. High-frequency depositional sequences of the upper part of the Kazusa Group, a middle Pleistocene forearc basin fill in Boso Pen- insula, Japan. Sedimentary Geology, v. 76, pp. 155-175.

Ito, M., and Katsura, Y., 1992, Inferred glacio-eustatic control for high-frequency depositional sequences of the Plio-Pleistocene Kazusa Group, a forearc basin fill in Boso Peninsula, Japan. Sedimentary Geology, v. 80, pp. 67-75.

Ito, M., 1998, Submarine fan sequences of the lower Kazusa Group, a Plio-Pleistocene forearc basin fill in the Boso Peninsula, Japan. Sedimentary Geology, v. 122, pp. 69-93.

Ito, M., Nishida, N., Otake, S., Saito, T., Okazaki, H., and Nishikawa, T., 2006a, Glacioeustatic signals and sequence architecture of the Pliocene-Pleistocene forearc basin-fill successions on the Boso Peninsula, central Japan. In: Ito, M., Yagishita, K., Ikehara, K., and Matsuda, H. (Eds.), Field Excursion Guidebook, 17th International Sedimentological Congress, Fukuoka, Japan. Sedimentological Society of Japan, FEA4, pp. 1-30.

Ito, M., Takao, A., Ishikawa, K., and Himeno, O., 2006b, A new avenue of sedimentological study of deep-water successions: Reorganization of the lowstand depositional model. Journal of the Japanese Association for Petroleum Technology, v. 71, pp. 21-33 (in Japanese with English abstract).

Ito, M., Kameo, K., Satoguchi, Y., Masuda, F., Hiroki, Y., Takano, O., Nakajima, T., and Suzuki, N., 2016, Neogene-Quaternary sedimentary successions. In: Moreno, T., Wallis, S., Kojima, T., Gibbons, W. (Eds.), The Geology of Japan, Geological Society of London, London, pp. 309-337.

Izumi, K., Haneda, Y., Suganuma, Y., Okada, M., Kubota, Y., Nishida, N., Kawamata, M., and Matsuzaki, T., 2020, Multiproxy sedimentological and geochemical analyses across the Lower-Middle Pleistocene boundary: Chemostratigraphy and paleoenvironment of the Chiba composite section, central Japan. Progress in Earth and Planetary Science (in press).

Jouzel, J., Masson-Delmotte, V., Cattani, O., Dreyfus, G., Falourd, S., Hoffmann, G., Minster, B., Nouet, J., Barnola, J.M., Chappellaz, J., Fischer, H., Gallet, J.C., Johnsen, S., Leuenberger, M., Loulergue, L., Luethi, D., Oerter, H., Parrenin, F., Raisbeck, G., Raynaud, D., Schilt, A., Schwander, J., Selmo, E., Souchez, R., Spahni, R., Stauffer, B., Steffensen, J.P., Stenni, B., Stocker, T.F., Tison, J.L., Werner, M., and Wolff, E.W., 2007, Orbital and millennial Antarctic climate variability over the past 800,000 years. Science, v. 317, pp. 793-796.

Kamemaru, A., 1996, Biostratigraphy of the Chiba Section of the Boso Peninsula toward establishing the Lower-Middle Pleistocene Boundary Stratotype based on benthic foraminiferal evidence. Proceedings on the Research of Stratotype for the Lower-Middle Pleistocene Boundary. Internal Research Group for the Lower-Middle, Middle-Upper Pleistocene Boundary, Japan Association for Quaternary Research, pp. 46-54.

Kameo, K., Okada, M., El-Masry, M., Hisamitsu, T., Saito, S., Nakazato, H., Ohkouchi, N., Ikehara, M., Yasuda, H., Kitazato, H., and Taira, A., 2006, Age model, physical properties and paleoceanographic implications of the middle Pleistocene core sediments in the Choshi area, central Japan. Island Arc, v. 15, pp. 366-377.

Kameo, K., Kubota, Y., Haneda, Y., Suganuma, Y., and Okada, M., 2020, Calcareous nannofossil biostratigraphy of the Lower-Middle Pleistocene boundary of the GSSP, Chiba composite section in the Kokumoto Formation, Kazusa Group, and implications for sea-surface environmental changes. Progress in Earth and Planetary Science, v. 7, 36. doi:10.1186/s40645-020-00355-x

Kazaoka, O., Suganuma, Y., Okada, M., Kameo, K., Head, M.J., Yoshida, T., Kameyama, S., Nirei, H., Aida, N., and Kumai, H., 2015, Stratigraphy of the Kazusa Group, Central Japan: a high-resolution marine sedimentary sequence from the Lower to Middle Pleistocene. Quaternary International, v. 383, pp. 116-135.

Kitaba, I., Iwabe, C., Hyodo, M., Katoh, S., and Matsushita, M., 2009, Highresolution climate stratigraphy across the Matuyama-Brunhes transition from palynological data of Osaka Bay sediments in southwestern Japan. Palaeogeogrphy, Palaeoclimatology, Palaeoecology, v. 272, pp. 115-123. 
Kitaba. I., Hyodo, M., Katoh, S., and Matsushita, M., 2012, Phase-lagged warming and the disruption of climatic rhythms during the MatuyamaBrunhes magnetic polarity transition. Gondwana Research, v. 21, pp. 595-600.

Kitaba, I., Hyodo, M., Katoh, S., Dettman, D.L., and Sato, H., 2013, Midlatitude cooling caused by geomagnetic field minimum during polarity reversal. PNAS, v. 110, pp. 1215-1220.

Kitaba, I., Hyodo, M., Nakagawa, T., Katoh, S., Dettman, D.L., and Sato, H., 2017, Geological support for the Umbrella Effect as a link between geomagnetic field and climate. Scientific Reports, v. 7, 40682. doi: $10.1038 /$ srep 40682

Kubota, Y., Haneda, Y., Itaki, T., Hayashi, H., Shikoku, K., Izumi, K., Head, M.J., Suganuma, Y., Okada, M. Paleoceanography of the northwestern Pacific across the Early-Middle Pleistocene boundary (Marine Isotope Stages 20-18), Progress in Earth and Planetary Science (in press).

Kucera, M., and Kennett, J.P., 2000, Biochronology and evolutionary implications of Late Neogene California margin planktonic foraminiferal events. Marine Micropaleontology, v. 40, pp. 67-81.

Laskar, J., Robutel, P., Joutel, F., Gastineau, M., Correia, A., and Levrard, B., 2004, A long term numerical solution for the insolation quantities of the Earth. Astronomy Astrophysics, v. 428, pp. 261-285.

Lisiecki, L.E., and Raymo, M.E., 2005, A Pliocene-Pleistocene stack of 57 globally distributed benthic $\delta^{18} \mathrm{O}$ records. Paleoceanography, v. 20, Pa1003. doi:10.1029/2004PA001071

Locarnini, R.A., Mishonov, A.V., Antonov, J.I., Boyer, T.P., Garcia, H.E., Baranova, O.K., Zweng, M.M., Paver, C.R., Reagan, J.R., Johnson, D.R., Hamilton, M., and Seidov, D., 2013, World Ocean Atlas 2013, Volume 1: Temperature. Levitus, S. (Eds.), A. Mishonov Technical Ed.; NOAA Atlas NESDIS 73, $40 \mathrm{p}$.

Löwemark, L., and Werner, F., 2001, Dating errors in high-resolution stratigraphy: a detailed X-ray radiograph and AMS-14C study of Zoophycos burrows. Marine Geology, v. 177, pp. 191-198.

Macrì, P., Capraro, L., Ferretti, P., and Scarponi, D., 2018, A high-resolution record of the Matuyama-Brunhes transition from the Mediterranean region: The Valle di Manche section (Calabria, Southern Italy). Physics of the Earth and Planetary Interiors, v. 278, pp. 1-15.

Maiorano, P., and Marino, M., 2004, Calcareous nannofossil bioevents and environmental control on temporal and spatial patterns at the earlymiddle Pleistocene. Marine Micropaleontology, v. 53, pp. 405-422.

Maiorano, P., Bertini, A., Capolongo, D., Eramo, G., Gallicchio, S., Girone, A., Pinto, D., Toti, F., Ventruti, G., and Marino, M., 2016, Climate signatures through Marine Isotope Stage 19 in the Montalbano Jonico section (Southern Italy): A land-sea perspective. Palaeogeogrphy, Palaeoclimatology, Palaeoecology, v. 461, pp. 341-361.

Marino, M., Bertini, A., Ciaranfi, N., Aiello, G., Barra, D., Gallicchio, S., Girone, A., La Perna, R., Lirer, F., Maiorano, P., Petrosino, P., and Toti, F., 2015, Paleoenvironmental and climatostratigraphic insights for Marine Isotope Stage 19 (Pleistocene) at the Montalbano Jonico succession, South Italy. Quaternary International, v. 383, pp. 104-115.

Matsuoka, H., and Okada, H., 1990, Time-progressive morphometric changes of the genus Gephyrocapsa in the Quaternary sequence of the tropical Indian Ocean, Site 709. In: Dundan, R.A., Backman, J., Peterson, L.C., et al. (Eds.), Proceedings of the Ocean Drilling Program, Scientific Results, v. 115, pp. 255-270.

Mitchum, R.M., and Wagoner, J.C.V., 1991, High-frequency sequences and their stacking patterns: sequence-stratigraphic evidence of highfrequency eustatic cycles. Sedimentary Geology, v. 70, pp. 131-160.

Mitsunashi, T., Yazaki, K., Kageyama, K., Shimada, T., Ono, E., Yasukuni, N., Makino, T., Shinada, Y., Fujiwara, K., and Kamata, S., 1961, Geological maps of the oil and gas field of Japan no. 4, Futtsu-Otaki, 1:50,000. Geological Survey of Japan.

Mitsunashi, T., Kikuchi, T., Suzuki, Y., Hirayama, J., Nakajima, T., Oka, S., Kodama, K., Horiguchi, M., Katsurajima, T., Miyashita, M., Yazaki, K., Kageyama, K., Nasu, N., Kagami, M., Honza, E., Kimura, M., Nirei, H., Higuchi, S., Hara, Y., Huruno, K., Endo, T., Kawashima,
S., and Aoki, S., 1979, Explanatory text of the geological map of Tokyo Bay and adjacent areas. With miscellaneous map series (20). scale 1: 100,000. Geological Survey of Japan (in Japanese with English abstract).

Nakagawa, T., Tarasov, P.E., Nishida, K., Gotanda, K., and Yasuda, Y., 2002, Quantitative pollen-based climate reconstruction in central Japan: Application to surface and Late Quaternary spectra. Quaternary Science Reviews, v. 21, pp. 2099-2113.

Nakamura, K., Takao, A., and Ito, M., 2007, Geometry and internal organization of hyperpycnites associated with a shelf-margin delta, the Middle Pleistocene Kokumoto Formation on the Boso Peninsula of Japan. Journal of the Sedimentological Society of Japan, v. 64, pp. 6568 (in Japanese with English abstract).

Nanayama, F., Nakazato, H., Ooi, S., and Nakajima, R., 2016, Geology of the Mobara District. Quadrangle Series, 1:50,000, Geological Survey of Japan, AIST, 101p (in Japanese with English abstract).

Naya, T., Yamaguchi, M., and Mizuno, K., 2009, Occurrence horizons of diatom fossils and recognition of marine sediments in the Shobu Core (GS-SB-1), Saitama Prefecture, central Kanto plain, Japan. Bulletin of the Geological Survey of Japan, v. 60, pp. 245-256 (in Japanese with English abstract).

Niitsuma, N, 1971, Detailed study of the sediments recording the MatuyamaBrunhes geomagnetic reversal. The science reports of the Tohoku University. Second series, Geology, v. 43, pp. 1-39.

Niitsuma, N., 1976, Magnetic stratigraphy in the Boso Peninsula. Journal of the Geological Society of Japan, v. 82, pp. 163-181 (in Japanese with English abstract).

Nirei, H., Kusuda, T., Kazaoka, O., Tanaka, H., and Umetsu, K., 1989, Geological map of Chiba 1:100,000. Policy and Planning Department of Chiba prefecture.

Nishida, N., Kazaoka, O., Izumi, K., Suganuma, Y., Okada, M., Yoshida, T., Ogitsu, I., Nakazato, H., Kameyama, S., Kagawa, A., Morisaki, M., and Nirei, H., 2016, Sedimentary processes and depositional environments of a continuous marine succession across the Lower-Middle Pleistocene boundary: Kokumoto Formation, Kazusa Group, central Japan. Quaternary International, v. 397, pp. 3-15.

Nomade, S., Bassinot, F., Marino, M., Simon, Q., Dewilde, F., Maiorano, P., Isguder, G., Blamart, D., Girone, A., Scao, V., Pereira, A., Toti, F., Bertini, A., Combourieu-Nebout, N., Peral, M., Bourles, D.L., Petrosino, P., Gallicchio, S., and Ciaranfi, N., 2019, High-resolution foraminifer stable isotope record of MIS 19 at Montalbano Jonico, southern Italy: A window into Mediterranean climatic variability during a low-eccentricity interglacial. Quaternary Science Reviews, v. 205, pp. 106-125.

Oda, M., 1977, Planktonic foraminiferal biostratigraphy of the late Cenozoic sedimentary sequence, Central Honshu, Japan. The science reports of the Tohoku University. Second series, Geology, v. 48, pp. 1-76.

Oda, M., 1979, Boso Peninsula —eastern part—. In: Tsuchi, R (Eds.), Fundamental data on Japanese Neogene bio- and chronostratigraphy, Kurofune Printing Co. Ltd., Shizuoka, pp. 24-27 (in Japanese with English figures).

Ogg, J.G., Ogg, G.M., and Gradstein, F.M., 2016, A Concise Geologic Time Scale 2016. Elsevier, Boston, 240pp.

Okada, M., and Niitsuma, N., 1989, Detailed paleomagnetic records during the Brunhes-Matuyama geomagnetic reversal and a direct determination of depth lag for magnetization in marine sediments. Physics of the Earth and Planetary Interiors, v. 56, pp. 133-150.

Okada, M., Suganuma, Y., Haneda, Y., and Kazaoka, O., 2017, Paleomagnetic direction and paleointensity variations during the MatuyamaBrunhes polarity transition from a marine succession in the Chiba composite section of the Boso Peninsula, central Japan. Earth, Planets and Space, v. 69, 45. doi:10.1186/s40623-017-0627-1

Okazaki, Y., Timmermann, A., Menviel, L., Harada, N., Abe-Ouchi, A., Chikamoto, M.O., Mouchet, A., and Asahi, H., 2010, Deepwater formation in the North Pacific during the Last Glacial Termination. Science, v. 329, pp. 200-204.

Okuda, M., Nakazato, H., Miyoshi, N., Nakagawa, T., Okazaki, H., Saito, 
S., and Taira, A., 2006, MIS11-19 pollen stratigraphy from the 250-m Choshi core, northeast Boso Peninsula, central Japan: Implications for the early/mid-Brunhes (400-780 ka) climate signals. Island Arc, v. 15, pp. 338-354.

Onishi, I., 1969, Pollen flora of the Kazusa Group in the Boso Peninsula, Japan. Earth Science (Chikyu Kagaku), v. 24, pp. 222-224 (in Japanese with English abstract).

Pickering, K.T., Souter, C., Oba, T., Taira, A., Schaaf, M., and Platzman, E., 1999, Glacio-eustatic control on deep-marine clastic forearc sedimentation, Pliocene-mid-Pleistocene (c. 1180-600 ka) Kazusa Group. SE Japan. Journal of the Geological Society, London v. 156, pp. 125-136.

Pillans, B., 2003, Subdividing the Pleistocene using the Matuyama-Brunhes boundary (MBB): an Australasian perspective. Quaternary Science Reviews, v. 22, pp. 1569-1577.

Prokopenko, A.A., Hinnov, L.A., Williams, D.F., and Kuzmin, M.I., 2006, Orbital forcing of continental climate during the Pleistocene: a complete astronomically tuned climatic record from Lake Baikal, SE Siberia. Quaternary Science Reviews, v. 25, pp. 3431-3457.

Raffi, I., Backman, J., Rio, D., and Shackleton, N.J., 1993, Plio-Pleistocene nannofossil biostratigraphy and calibration of oxygen isotope stratigraphies from Deep Sea Drilling Project Site 607 and Ocean Drilling Program Site 677. Paleoceanography, v. 8, pp. 387-408.

Raisbeck, G.M., Yiou, F., Cattani, O., and Jouzel, J., 2006, ${ }^{10}$ Be evidence for the Matuyama-Brunhes geomagnetic reversal in the EPICA Dome C ice core. Nature, v. 444, pp. 82-84.

Regattieri, E., Giaccio, B., Mannella, G., Zanchetta, G., Nomade, S., Tognarelli, A., Perchiazzi, N., Vogel, H., Boschi, C., Drysdale, R.N., Wagner, B., Gemelli, M., and Tzedakis, P., 2019, Frequency and dynamics of millennial-scale variability during Marine Isotope Stage 19: Insights from the Sulmona Basin (central Italy). Quaternary Science Reviews, v. 214 , pp. $28-43$.

Remane, J., Bassett, M.G., Cowie, J.W., Gohrbandt, K.H., Lane, H.R., Michelsen, O., and Wang, N., with the cooperation of members of ICS, 1996, Revised guidelines for the establishment of global chronostratigraphic standards by the International Commission on Stratigraphy (ICS). Episodes, v. 19, pp. 77-81.

Richmond, G.M., 1996, The INQUA-approved provisional Lower-Middle Pleistocene boundary. In: Turner, C. (Eds.), The Early-Middle Pleistocene in Europe. Balkema, Rotterdam, pp. 319-327.

Sánchez Goñi, M.F., Rodrigues, T., Hodell, D.A., Polanco-Martínez, J.M., Alonso-García, M., Hernández-Almeida, I., Desprat, S., Ferretti, P., 2016. Tropically-driven climate shifts in southwestern Europe during MIS 19, a low eccentricity interglacial. Earth and Planetary Science Letters, v. 448, pp. 81-93.

Sagnotti, L., Cascella, A., Ciaranfi, N., Macrì, P., Maiorano, P., Marino, M., and Taddeucci, J., 2010, Rock magnetism and palaeomagnetism of the Montalbano Jonico section (Italy): Evidence for late diagenetic growth of greigite and implications for magnetostratigraphy. Geophysical Journal International, v. 180, pp. 1049-1066.

Sato, T., Takayama, T., Kato, M., Kudo, T., Kameo, K., 1988, Calcareous microfossil biostratigraphy of the uppermost Cenozoic formations distributed in the coast of the Japan Sea, Part 4: Conclusion. Journal of the Japanese Association of Petroleum Technologist, v. 53, pp. 474-491 (in Japanese with English abstract).

Sato, T., and Takayama, T., 1992, A stratigraphically significant new species of the calcareous nannofossil Reticulofenestra asanoi. In: Ishizaki, K., and Saito, T. (eds.), Centenary of Japanese Micropaleontology: contributed Papers in honor of Professor Yokichi Takayanagi, Terra Scientific Publishing Company, Tokyo, pp. 457-460.

Sato, T., Kameo, K., and Mita, I., 1999, Validity of the latest Cenozoic calcareous nannofossil datums and its application to the tephrochronology. Earth Science (Chikyu Kagaku), v. 53, pp. 265-274 (in Japanese with English abstract).

Satoguchi, Y., and Nagahashi, Y., 2012, Tephrostratigraphy of the Pliocene to Middle Pleistocene Series in Honshu and Kyushu Islands,
Japan. Island Arc, v. 21, pp. 149-169.

Schlitzer, R., 2015. Ocean Data View. http://odv.awi.de.

Seno, T., and Takano, T., 1989, Seismotectonics at the trench-trench-trench triple junction off central Honshu. Pure and Applied Geophysics, v. 129, pp. 27-40.

Shikoku, K., Hayashi, H., and Nozawa, R., Refining the planktonic foraminiferal biostratigraphy around the Matuyama-Brunhes boundary of the upper part of the Kazusa Group, central Honshu, Japan. Paleontological Research (in revision).

Simon, Q., Thouveny, N., Bourlès, D.L., Valet, J.-P., Bassinot, F., Ménabréaz, L., Guillou, V., Choy, S., and Beaufort, L., 2016, Authigenic ${ }^{10} \mathrm{Be} /{ }^{9} \mathrm{Be}$ ratio signatures of the cosmogenic nuclide production linked to geomagnetic dipole moment variation since the Brunhes/Matuyama boundary. Journal of Geophysical Research, v. 121, pp. 7716-7741.

Simon, Q., Bourlès, D.L., Bassinot, F., Nomade, S., Marino, M., Ciaranfi, N., Girone, A., Maiorano, P., Thouveny, N., Choy, S., Dewilde, F., Scao, V., Isguder, G., and Blamart, D., 2017, Authigenic ${ }^{10} \mathrm{Be} /{ }^{9} \mathrm{Be}$ ratio signature of the Matuyama-Brunhes boundary in the Montalbano Jonico marine succession. Earth and Planetary Science Letters, v. 460, pp. 255-267.

Simon, Q., Bourlès, D. L., Thouveny, N., Horng, C.-S., Valet, J.-P., Bassinot, F., and Choy, S., 2018a, Cosmogenic signature of geomagnetic reversals and excursions from the Réunion event to the MatuyamaBrunhes transition (0.7-2.14 Ma interval). Earth and Planetary Science Letters, v. 482, pp. 510-524.

Simon, Q., Thouveny, N., Bourlès, D. L., Bassinot, F., Savranskaia, T., and Valet, J.-P., 2018b, Increased production of cosmogenic ${ }^{10} \mathrm{Be}$ recorded in oceanic sediment sequences: Information on the age, duration, and amplitude of the geomagnetic dipole moment minimum over the Matuyama-Brunhes transition. Earth and Planetary Science Letters, v. 489, pp. 191-202.

Simon, Q., Suganuma, Y., Okada, M., Haneda, Y., and ASTER Team, 2019, High-resolution ${ }^{10} \mathrm{Be}$ and paleomagnetic recording of the last polarity reversal in the Chiba composite section: Age and dynamics of the Matuyama-Brunhes transition. Earth and Planetary Science Letters, v. 519, pp. 92-100.

Singer, B.S., Jicha, B.R., Mochizuki, N., and Coe, R.S., 2019, Synchronizing volcanic, sedimentary, and ice core records of Earth's last magnetic polarity reversal. Science Advances, v. 5, eaaw4621. doi:10.1126/sciadv. aaw4621

Suganuma, Y., Yokoyama, Y., Yamazaki, T., Kawamura, K., Horng, C.S., and Matsuzaki, H., 2010, ${ }^{10}$ Be evidence for delayed acquisition of remanent magnetization in marine sediments: Implication for a new age for the Matuyama-Brunhes boundary. Earth and Planetary Science Letters, v. 296, pp. 443-450.

Suganuma, Y., Okada, M., Horie, K., Kaiden, H., Takehara, M., Senda, R., Kimura, J., Haneda, Y., Kawamura, K., Kazaoka, O., and Head, M.J., 2015, Age of Matuyama-Brunhes boundary constrained by U-Pb zircon dating of a widespread tephra. Geology, v. 43, pp. 491-494.

Suganuma, Y., Haneda, Y., Kameo, K., Kubota, Y., Hayashi, H., Itaki, T., Okuda, M., Head, M.J., Sugaya, M., Nakazato, H., Igarashi, A., Shikoku, K., Hongo, M., Watanabe, M., Satoguchi, Y., Takeshita, Y., Nishida, N., Izumi, K., Kawamura, K., Kawamata, M., Okuno, J., Yoshida, T., Ogitsu, I., Yabusaki, H., and Okada, M., 2018, Paleoclimatic and paleoceanographic records of Marine Isotope Stage 19 at the Chiba composite section, central Japan: A reference for the Early-Middle Pleistocene boundary. Quaternary Science Reviews, v. 191, pp. 406-430.

Sun, Y., An, Z., Clemens, S.C., Bloemendal, J., and Vandenberghe, J., 2010, Seven million years of wind and precipitation variability on the Chinese Loess Plateau. Earth and Planetary Science Letters, v. 297, pp. 525-535.

Takao, A., Nakamura, K., Takaoka, S., Fuse, M., Oda, Y., Shimano, Y., Nihisda, N., and Ito, M., 2020, Spatial and temporal variations in depositional systems in the Kazusa Group: insights into the origins of deep-water massive sandstones in Pleistocene forearc basin on the 
Boso Peninsula, Japan. Progress in Earth and Planetary Science, v. 7, 37. doi:10.1038/srep40682

Takeshita, Y., Matsushima, N., Teradaira, H., Uchiyama, T., and Kumai, H., 2016, A marker tephra bed close to the Middle Pleistocene boundary: Distribution of the Ontake-Byakubi tephra in central Japan. Quaternary International, v. 397, pp. 27-38. doi:10.1016/j.quaint.2015.03.054

Tanaka, I, Hyodo, M, Kitaba, I, Ueno, U, and Sato H., 2017, Diatom-based paleoceanographic variability across the Early-Middle Pleistocene transition from the Chiba section, central Japan. Quaternary International, v. 455, pp. 141-148.

Tanaka, S., and Takahashi, K., 2008, Detailed vertical distribution of radiolarian assemblage (0-3000 m, fifteen layers) in the central subarctic Pacific, June 2006. Memoirs of the Faculty of Science, Kyushu University, Series D, Earth \& Planetary Science, v. 32, pp. 49-72.

The Japanese Association for Petroleum Technology, 2013, Sekiyukogyobinran (Petroleum Technology Handbook). The Japanese Association for Petroleum Technology, Tokyo, 960 p. (in Japanese)

Toti, F., 2015. Interglacial vegetation patterns at the Early-Middle Pleistocene transition: A point of view from the Montalbano Jonico section (Southern Italy). Alpine and Mediterranean Quaternary, v. 28, pp. 131-143.

Tsuji, T., Miyata, Y., Okada, M., Mita, I., Nakagawa, H., Sato, Y., and Nakamizu, M., 2005, High-resolution chronology of the lower Pleistocene Otadai and Umegase Formations of the Kazusa Group, Boso Peninsula, central Japan: Chronostratigraphy of the JNOC TR-3 cores based on oxygen isotope, magnetostratigraphy and calcareous nannofossil. Journal of the Geological Society of Japan, v. 111, pp. 1-20 (in Japanese with English abstract).

Tzedakis, P.C., Channell, J.E.T., Hodell, D.A., Kleiven, H.F., and Skinner, L.C., 2012, Determining the natural length of the current interglacial. Nature Geoscience, v. 5, pp. 138-142.

Uchman, A., and Wetzel, A., 2012, Deep-sea fans. In: Knaust, D., Bromley, R.G., (eds.), Trace Fossils as Indicators of Sedimentary Environments. Developments in Sedimentology, v. 64, pp. 643-672.

Ueki, T., Yamaguchi, M., Hongo, M., Naya, T., and Mizuno, K., 2009, Paleomagnetic and rock-magnetic measurements of the GS-SB-1 core at Shobu Town, central Kanto Plain, Japan. Bulletin of the Geological Survey of Japan, v. 60, pp. 199-243 (in Japanese with English abstract).

Ueno, Y., Hyodo, M., Yang, T., and Katoh, S., 2019, Intensified East Asian winter monsoon during the last geomagnetic reversal transition. Scien-

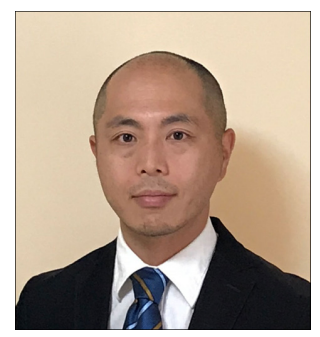

Yusuke Suganuma is an Associate Professor of the National Institute of Polar Research and the Graduate University for Advanced Studies (SOKENDAI), Japan. He is an Advisory Board member of the INQUA Commission on Stratigraphy and Chronology (INQUASACCOM) (2015-) and a Steering Committee member of the PAST ANTARCTIC ICE SHEET DYNAMICS (PAIS), under the Scientific Committee on Antarctic Research (SCAR) (2014-). He was a member of International Subcommission on Quaternary Stratigraphy (SQS) Working Group on the Lower-Middle Pleistocene Subseries Boundary (20172020).

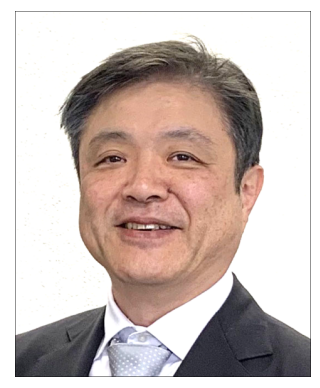

Makoto Okada is a Professor of Earth Sciences, and presently Vice-Dean of the College of Science at Ibaraki University, Japan, He is also concurrently serving as a visiting professor of the Research Institute for Time Studies at Yamaguchi University, Japan. He is an Advisory Board member of the INQUA Commission on Stratigraphy and Chronology (INQUA-SACCOM) (2015-), and serves on the Executive Committee of the Geological Society of Japan (2016-). tific Reports, v. 9, 9389. doi:10.1038/s41598-019-45466-8

Ujihara, A., 1986, Pelagic Gastropoda assemblages from the Kazusa Group of the Boso Peninsula, Japan and Plio-Pleistocene climatic changes. Journal of the Geological Society of Japan, v. 92, pp. 639-651 (in Japanese with English abstract).

Valet, J.-P., Fournier, A., Courtillot, V., and Herrero-Bervera, E., 2012 , Dynamical similarity of geomagnetic field reversals. Nature, v. 490, pp. 89-93.

Valet, J.-P., Bassinot, F., Bouilloux, A., Bourlès, D., Nomade, S., Guillou, V., Lopes, F., Thouveny, N., and Dewilde, F., 2014, Geomagnetic, cosmogenic and climatic changes across the last geomagnetic reversal from Equatorial Indian Ocean sediments. Earth and Planetary Science Letters, v. 397, pp. 67-79.

Valet, J.-P., and Fournier, A., 2016, Deciphering records of geomagnetic reversals. Reviews of Geophysics, v. 54, pp. 410-446.

Valet, J.-P., Bassinot, F., Simon, Q., Savranskaia, T., Thouveny, N., Bourlés, D.L., and Villedieu, A., 2019, Constraining the age of the last geomagnetic reversal from geochemical and magnetic analyses of Atlantic, Indian, and Pacific Ocean sediments. Earth and Planetary Science Letters, v. 506, pp. 323-331.

Wade, B.S., Pearson, P.N., Berggren, W.A., and Païlike, H., 2011, Review and revision of Cenozoic tropical planktonic foraminiferal biostratigraphy and calibration to the geomagnetic polarity and astronomical time scale. Earth-Science Reviews, v. 104, pp. 111-142.

Wennrich, V., Minyuk, P.S., Borkhodoev, V., Francke, A., Ritter, B., Nowaczyk, N.R., Sauerbrey, M.A., Brigham-Grette, J., and Melles, M., 2014, Pliocene to Pleistocene climate and environmental history of Lake El'gygytgyn, Far East Russian Arctic, based on high-resolution inorganic geochemistry data. Climate of the Past, v. 10, pp. 1381-1399.

Wetzel, A., and Uchman, A., 2012, Hemipelagic and pelagic basin plains. In: Knaust, D., Bromley, R.G., (eds.), Trace Fossils as Indicators of Sedimentary Environments. Developments in Sedimentology, v. 64, pp. 673-702.

Yoshioka, K., 1973, Plant Geography. Kyoritsu-Shuppan publishing house, Tokyo, 84 p. (in Japanese).

Zhang, Y., and Huang, D., 2011, Has the East Asian westerly jet experienced a poleward displacement in recent decades? Advances in Atmospheric Sciences, v. 28, pp. 1259-1265.

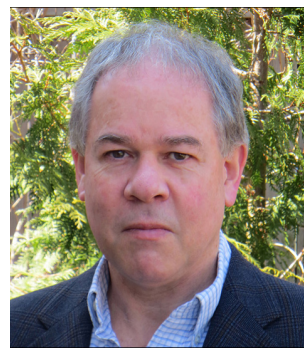

Martin J. Head is a Professor of Earth Sciences at Brock University, Canada, and concurrently holds a status-only professorship at the University of Toronto, Canada. He is presently Vice-Chair of the International Subcommission on Quaternary Stratigraphy (SQS), having served as its Chair (2012-2020). He was Co-Convener of the SQS Working Group on the Lower-Middle Pleistocene Subseries Boundary (2010-2020) and is Co-Convener of its Working Group on the Middle-Upper Pleistocene Subseries Boundary. He is a voting member of the SQS Anthropocene Working Group and of the International Subcommission on Stratigraphic Classification, and is a member of the INQUA Commission on Stratigraphy and Chronology (SACCOM) (2007-). 